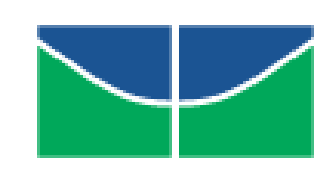

UNIVERSIDADE DE BRASÍLIA - UnB

FACULDADE DE EDUCAÇÃO - FE

PROGRAMA DE PÓS-GRADUAÇÃO EM EDUCAÇÃO

ANA BÁRBARA DA SILVA NASCIMENTO

AS CONTRIBUIÇÕES DA FILOSOFIA DA DIFERENÇA NA ERA DOS ALUNOS COM SUPOSTOS TRANSTORNOS DE APRENDIZAGEM

BRASÍLIA-DF 


\title{
AS CONTRIBUIÇÕES DA FILOSOFIA DA DIFERENÇA NA ERA DOS ALUNOS COM SUPOSTOS TRANSTORNOS DE APRENDIZAGEM
}

\author{
Dissertação de Mestrado apresentada ao \\ Programa de Pós-Graduação em \\ Educação da Universidade de Brasília, \\ como requisito para obtenção do Título de \\ Mestre em Educação, sob a orientação da \\ Prof ${ }^{a}$. Dra . Sílvia Ester Orrú.
}

Brasília - DF 


\title{
AS CONTRIBUIÇÕES DA FILOSOFIA DA DIFERENÇA NA ERA DOS ALUNOS COM SUPOSTOS TRANSTORNOS DE APRENDIZAGEM
}

\author{
Banca Examinadora
}

Profa . Dra . Sílvia Ester Orrú - Orientadora

Faculdade de Educação - PPGE - UnB

Profa . Dra. Sônia Aparecida Siquelli

Faculdade de Educação - PPGE - UNIVÁS

Profa . Dra . Patrícia Lima Martins Pederiva

Faculdade de Educação - PPGE - UnB

Profa $^{a}$. Dra ${ }^{a}$. Viviane Neves Legnani

Faculdade de Educação - PPGE - UnB (Suplente)

Brasília, 10 de dezembro de 2015. 
Ao meu marido Olavo Filho, minha Mãe Elza e aos meus filhos Amanda Sophia, Heitor Henrique e Olavo Neto, por serem a força e o alicerce na constituição de uma mulher com muitos olhares de amor, aprendizado e cuidado. 


\section{Agradecimentos}

Agradeço a Deus em sua infinita glória pela oportunidade de passar por esta vida, para aprender e ensinar, para viver e ser vivida em muitas oportunidades que foram e ainda me são dadas.

A minha Mãe-Pai, minha "Pãe", que com sua força, dedicação, esperança e consciência me conduziu pelo caminho da busca por uma vida melhor, me encaminhou para conquistas que trilhadas pelos meus pés estavam pousadas em seus sonhos e assim continuamos a caminhar juntas, às vezes refrescadas em brisas, às vezes angustiadas em meio a furacões, mas sem perder a unidade e singularidade dessa relação única: a maternidade.

Ao meu marido Olavo Filho, pelas mãos, a mente, a força, a determinação e o coração que me ajudaram a escrever este trabalho, por acreditar mais em mim do que muitas vezes eu mesma. Pela dedicação, doação e disciplina espartana, porque não dizer sertaneja-candanga, em arar em solo fértil comigo a semente que deu os frutos de um sonho que pôde expor uma realidade carente de reflexão e tomada de atitude.

A minha filha Amanda Sophia por me ensinar desde muito cedo que "amar se aprende amando" como diz o poeta. Sopro de vida na minha vida! Seus olhos negros e brilhantes me fazem querer sempre mais. Estamos juntas há muito tempo, essa é uma escolha feita de coração para coração. Nascemos assim: uma para a outra.

A meu filho Heitor Henrique por me ensinar a crescer no amor e na esperança de dias cada vez melhores e mais cheios de vitórias. Um dia de cada vez! Crescendo juntos na luta por constituir uma relação que nos engrandece e nos faz participantes de um mundo cheio de descobertas, desafios e sorrisos abertos, acompanhadas de suas gargalhadas sonoras.

Ao meu filho Olavo Neto por me ensinar a ser eu, pelo encontro com uma identidade desconhecida. Me encontrei ao me ver em seus olhos. Há muito amor nessa casa, na casa que você fez mim. Pintou, bordou, escreveu, talhou, tatuou com seu DNA em mim todo amor que houver nessa vida. Meu céu e meu chão de estrelas verdadeiras e da vida inteira.

A minha família (tias, tios, primos, primas, afilhado) pela confiança, admiração e crença na minha capacidade investigativa, ao incentivo pela minha paixão pelo 
saber. Pela credibilidade de que através do estudo e do conhecimento eu poderia oferecer uma vida melhor para aqueles que amo.

A minha sogra Maria Luzia pelos sorrisos empolgados, pelo incentivo na continuação da minha formação e pelo exemplo e apoio familiar que sempre me foi dado. Estudar sempre!

A Professora Doutora Sílvia Ester Orrú que acreditou no meu trabalho, oportunizou minha formação, orientou com sabedoria e personalidade o desenvolvimento desta pesquisa. Senti-me acolhida, orientada, assistida, ouvida e prestigiada nessa relação de construção de saberes.

Aos meus colegas do curso de Mestrado que contribuíram com opiniões, comentários, indicações de leituras e principalmente com a partilha de ideias. Uma vida de saberes e sabores vividos juntinha no aperto desses dois anos.

Aos meus colegas de trabalho que sempre me incentivam e ouvem com atenção aquilo que eu empolgadamente e apaixonadamente "desembesto" (usando um bom nordestinês) a falar sobre este trabalho.

Aos professores participantes da minha Defesa Qualificação: Professora Doutora Sílvia Orrú - UnB (minha Orientadora), Professora Doutora Patrícia Pederiva - UnB e Professor Doutor Walter Matias Lima - UFAL, pelos apontamentos necessários e sábios para o desenvolvimento de um trabalho lindo e gratificante.

Aos sujeitos participantes dessa pesquisa e as suas famílias, que confiaram a mim suas histórias, suas dores e seus amores. Esse trabalho só pôde existir por causa dessa generosidade viva de cada um de vocês.

Aos mestres da Universidade Federal de Alagoas - UFAL, onde comecei toda a minha formação. Muito orgulhosa sou de ter feito parte dessa família. Orgulho este que se faz presente no orgulho de ser Nordestina.

Aos mestres da Universidade de Brasília - UnB pela oportunidade de poder estudar, conhecer, debater, aprender e dividir muitos saberes, o desafio foi maior do que a oportunidade, mas a oportunidade foi essencial.

A CAPES, pelos meses que me apoiou me concedendo uma bolsa de estudos para que eu pudesse me dedicar somente ao Mestrado.

Aqueles que estão na minha vida, meus amigos (tão caros para mim) ou estiveram em momentos pontuais ou casuais que com um sorriso, uma frase, um elogio, um consolo, um acalento, não me permitiram fracassar. São muitos os nomes para serem listados aqui, mas a minha memória não os esquece confirmando 
minhas raízes, raízes estas de um povo que ama suas histórias e não esquece com facilidade o solo fértil, às vezes árido de onde essas mesmas histórias brotaram.

Aos professores que estão na Defesa Final deste trabalho: Professora Doutora Inês Maria Marques Zanforlin Pires de Almeida, Professora Doutora Sílvia Ester Orrú, Professora Doutora Sônia Aparecida Siquelli, Professora Doutora Patrícia Lima Martins Pederiva e Professora Doutora Viviane Neves Legnani pela disponibilidade, confiança e interesse em ouvir, ler e discutir esse tema tão caro para $\operatorname{mim}$.

A Brasília por me dar uma vida cheia de bonitezas, ipês coloridos e alegrias, como diria Djavan: "Céu de Brasília traço do arquiteto, gosto tanto dela assim..."

Por fim, aos meus alunos, como eu mesma digo: "lindos de viver", cada um em sua singularidade que me fazem ser uma pessoa infinitamente melhor todos os dias da minha vida, a experiência de ser e estar com vocês me embeleza a mente e arrefece a alma. 


\section{Resumo}

A homogeneidade tem sido o ponto de partida geral na Educação quando se trata de entender as diferenças apresentadas pelos estudantes no meio escolar. De fato, a Educação é apenas um exemplo de uma atitude muito mais geral relacionada à noção de homogeneidade e aos conceitos que the acompanham de perto, como aquele de normalidade. Procuraremos mostrar que essa tendência a se olhar a diferença a partir da homogeneidade tem sido um empecilho ao problema da inclusão escolar. Este trabalho pretende abordar a questão da Educação tomando por ponto de partida a noção de SINGULARIDADE, entendida como o caso extremo da diferença e irredutível à semelhança, diferindo, assim, da perspectiva usual. Para atingir nossos objetivos, apresentamos, no primeiro capítulo, uma arqueologia conceitual da noção de "dificuldade de aprendizagem e desenvolvimento" para mostrar, primeiramente, como tal noção está profundamente influenciada pelo contexto histórico e social em que se apresenta. Mostramos, de fato, que essa noção sofreu constantes deslizamentos hermenêuticos ao longo da história. Para tanto, apresentamos três abordagens filosóficas distintas, características de épocas diferentes, que conceituam "dificuldade de aprendizagem e desenvolvimento" de formas bem diferentes. Discutimos, então, as origens estruturais e as consequências do paradigma hegemônico da era contemporânea. Baseado na noção de ritmo e eficiência, mostramos, no segundo capítulo, que esse paradigma se mantém conceitual e logicamente sustentado pela ideologia da medicalização. Analisamos, ainda, os pressupostos da própria medicalização, argumentando que muito da sua pretensa objetividade pode estar assentada, de fato, no desenvolvimento da chamada profecia autorrealizadora. Nesse contexto, consideramos especificamente o instrumento da prova diferenciada. Após essa abordagem crítica, passamos a mostrar que o elemento que perpassa todas as noções de normalidade, distúrbio psiquiátrico e dificuldade de aprendizagem, independentemente do momento histórico em que ocorram, é a assumida precedência de uma mesmidade ontológica relativa ao humano, levando à qualificação da diferença quase sempre em termos negativos. Apresentamos, no capítulo três, nossos próprios argumentos em favor de uma ontologia da singularidade (para além da mera diferença). Nesse contexto, emprestamos a noção de MAL-EsTAR, da chamada Filosofia Clínica, como uma contraposição àquelas de doença, síndrome ou transtorno, o que nos permite propor mecanismos para se superar a ideologia medicalizante já criticada. Como forma de caracterizar adequadamente a noção de MAL-ESTAR, apresentamos, no capítulo quatro, uma pesquisa qualitativa com três sujeitos experimentais que apresentam diagnósticos de transtorno de aprendizagem. Com isso, torna-se possível traçar uma zona cinzenta separando eventuais doenças, síndromes ou transtornos daquilo que efetivamente impede o desenvolvimento escolar, que caracterizamos como sendo o MAL-ESTAR. Nesse sentido, a pesquisa qualitativa foi feita de modo a dar voz a esses sujeitos experimentais, para que suas percepções sobre si possam ser apreendidas sem a lente medicalizante. Os resultados da pesquisa qualitativa sugerem os efeitos 
já mencionados e criticados em capítulos anteriores, vinculados à ideologia da medicalização. Mostram, ainda, que, para além da existência ou não de um substrato que indique doença, os sujeitos experimentais se fazem perpassar por uma enorme carga de MAL-ESTAR, principalmente relacionado com suas autoimagens. Concluímos, portanto, que a adoção de uma perspectiva que assume a diferença como ontologicamente precedente relativamente ao conceito de uniformidade não é suficiente para instaurar um ponto de partida para a questão da inclusão escolar, uma vez que a diferença, constituída sobre os pilares de abordagens estatísticas, mantém implícito o referencial da homogeneidade. Como forma de elucidar todas essas questões, apresentamos um exemplo que permite compreender o diferencial de nossa abordagem de situações educacionais importantes daquela usual, e como tais situações educacionais importantes podem se beneficiar de tal ontologia da singularidade.

Palavras-chave: Educação, Filosofia, Singularidade, Medicalização, Transtornos de Aprendizagem. 


\begin{abstract}
Homogeneity has been generally considered the adequate point of departure in educational matters. In fact, Education is just an example of a much wider attitude in the whole social tissue of our contemporaneous society. Other concepts like the one of normality are natural companions to homogeneity. We intend to show that this tendency to look at differences from the perspective of homogeneity has been an obstacle for the solution of the problem of having a more inclusive Education. We argue that the assumption of precedence of ontological singularity may be an adequate substitute for the assumption of homogeneity. Thus, this work intends to address the issue of Education taking into account as its starting point the notion of Singularity, as an extreme case of difference and as something irreducible to homogeneity. To attain our objectives, we present, in the first chapter, an archeology of the notion of "learning and development disabilities" to show, firstly, how such a notion is deeply influenced by the historical and social context in which it is immersed. We do that using three philosophical approaches which were characteristic of their times. We show that these approaches understood the notion of "learning and development disabilities" in quite different ways. We then discuss the structural origins and consequences of the hegemonic paradigm on that matter in the realm of contemporaneity. Based upon the notions of rhythm and efficiency, we show, in the second chapter, that this paradigm is logically and conceptually upheld by the ideology of medicalization. We thus analyze the presuppositions of medicalization, arguing that much of its pretense objectivity may be the outcome of the so called self realizing prophecy. In this context, we specifically consider the instrument known as the "differentiated exam". After these critical developments, we proceed to show that the element that is present in all the presented notions of normality, psychiatric disorder or learning disability, with independence to the historic moment in which they occurred, is the assumption of an ontological precedence of the notion of sameness with respect to Human Beings, making the qualification of difference almost always to occur in negative terms. We present, in chapter three, our own arguments in favor of a Singularity Ontology (beyond mere difference). In this context, we borrow the notion of UNEASINESS from the field of Clinical Philosophy as a contraposition to those of illness or syndrome. This allows us to propose mechanisms that may overcome the ideology of medicalization already mentioned. As a way to adequately characterize the theoretical concept of UNEASINESS, we present, in chapter four, a qualitative research with three experimental subjects presenting diagnostics of learning disorder. This makes it possible to draw a gray zone separating eventual diseases or syndromes from UNEASINESS, which is what makes it harder for someone to develop in educational contexts. In this sense, the qualitative research was made to give voice to these experimental subjects and allow them to express their perceptions about themselves without the lenses of medicalization. The results obtained with the qualitative research suggest the mentioned effects connected to the ideology of medicalization. Furthermore, they
\end{abstract}


show that beyond the effective existence of some disease, the experimental subjects present an enormous sense of Uneasiness. This latter mainly related to their self images.

We conclude, thus, that the adoption of a perspective which assumes the mere difference as ontologically precedent to uniformity is not sufficient to uphold a point of departure for inclusion in educational contexts. Indeed, we show that this approach is frequently based upon statistical notions. Because of this, it keeps itself within the sameness referential. We then present a specific example as a means to show how different outcomes an approach based on singularity will deliver, when compared to the usual one, and how important educational situations can benefit from such ONTOLOGY OF SINGULARITY.

Key-words: Education, Philosophy, Singularity, Medicalization, Learning disabilities. 


\section{Lista de abreviaturas e siglas}

DSM-V - Diagnóstico e Estatística de Transtornos Mentais V

TCLE - Termo de Consentimento Livre e Esclarecido

TDAH - Transtorno do Deficit de Atenção com Hiperatividade

TEPT - Transtorno do Estresse Pós-Traumático

TOD - Transtorno Opositivo-Desafiador 


\section{Lista de figuras}

Figura 1 - Propaganda da Prefeitura do Rio de Janeiro publicada no jornal O Globo

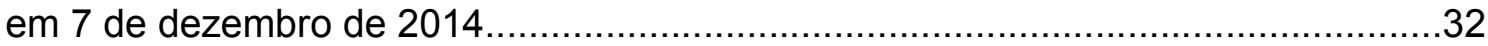

Figura 2 - Representação esquemática da média, da mediana e da moda para três

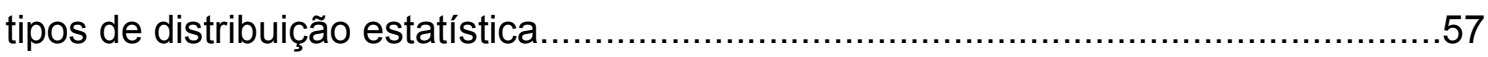

Figura 3 - A curtose mede o achatamento de uma curva estatística comparada com a curva normal (gaussiana). .58

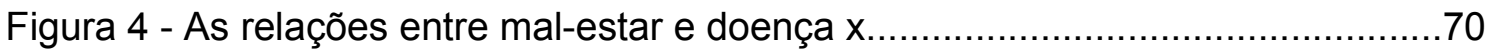




\section{SUMÁRIO}

INTRODUÇÃO

Capítulo 1 - A DIFICULDADE DE APRENDIZAGEM SOCIALMENTE

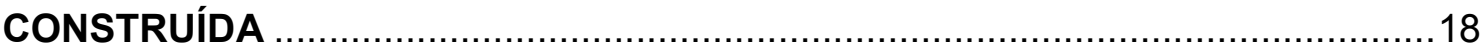

1.1 Introdução

1.20 conceito de "dificuldade de aprendizagem e desenvolvimento" e sua

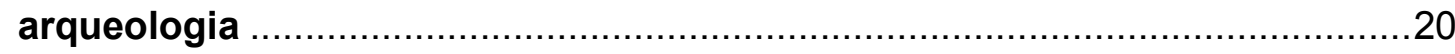

1.3 Antiguidade Clássica: a eliminação do imperfeito ....................................21

1.3.1 Platão e a deficiência de recordações...................................................22

1.3.2 Aristóteles e a deficiência de categorias ..............................................25

1.4 A Idade Média (476 d.C.-1453 d.C.): o mal como ausência de bem ...........27

1.4.1 Santo Agostinho e a deficiência de iluminação divina...............................27

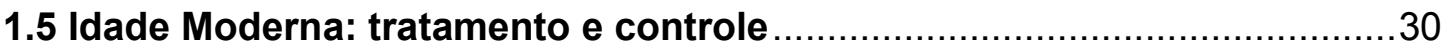

1.5.1 A sociedade burguesa e a deficiência de eficiência .....................................31

1.6 Idade Contemporânea: massificação e singularidade ...............................33

1.7 A dificuldade de aprendizagem como uma relação entre instâncias

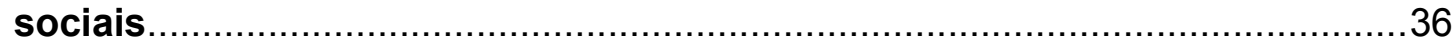

Capítulo 2 - A MEDICALIZAÇÃO COMO INSTRUMENTALIZAÇÃO DA MEDICINA 39

2.1 Introdução

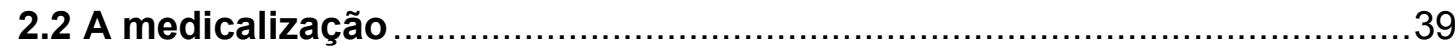

2.3 A ideologia da medicalização: remédios que fazem aprender ..................40

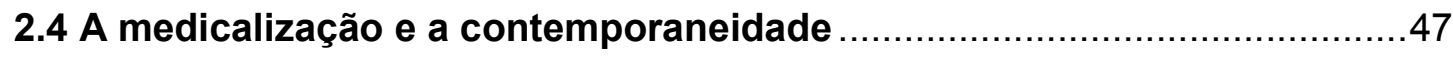

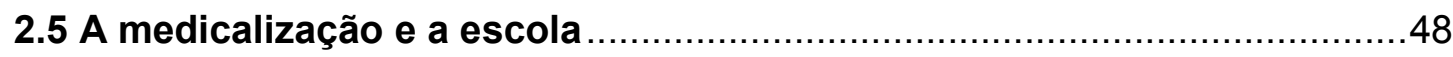

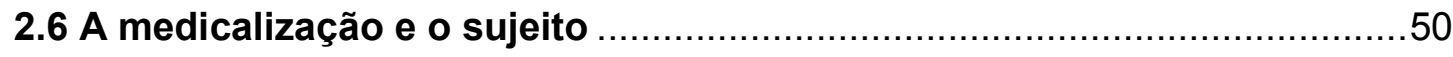

2.7 A medicalização e a expropriação do ensino pela supervaloração do

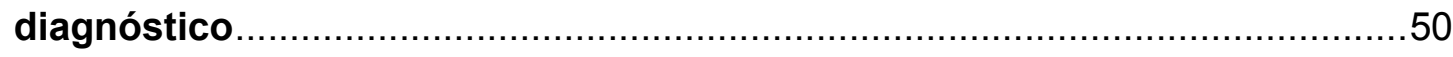


Capítulo 3 - CONTRIBUIÇÕES DA FILOSOFIA DA SINGULARIDADE POR UMA ESCOLA NÃO EXCLUDENTE

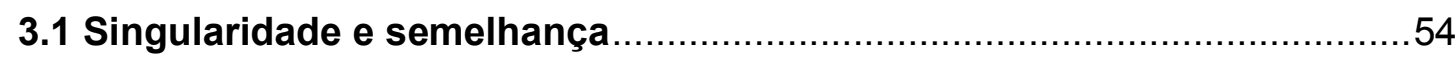

3.2 A estatística como forma de submeter a singularidade à generalidade...55

3.2.1 Média aritmética e outros descritores estatísticos...................................55

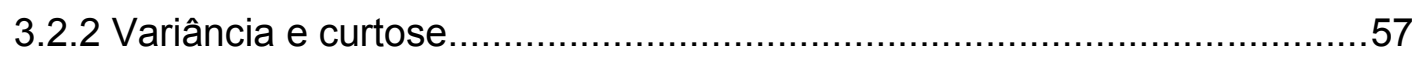

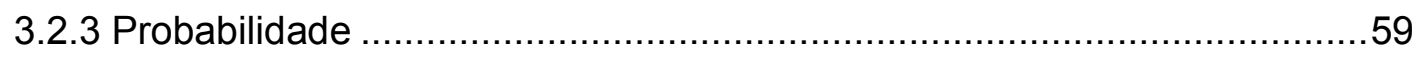

3.3 A relação da estatística com a medicalização ………………….................61

3.4 A fenomenologia da estatística e os DSMs ........................................62

3.5 A singularidade como ontologia de fundo para o problema da educação

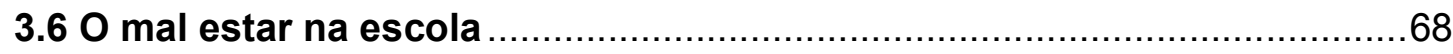

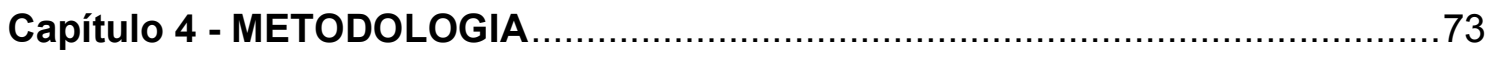

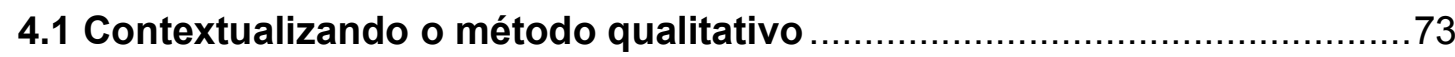

4.20 método qualitativo e a interação com esta pesquisa .............................74

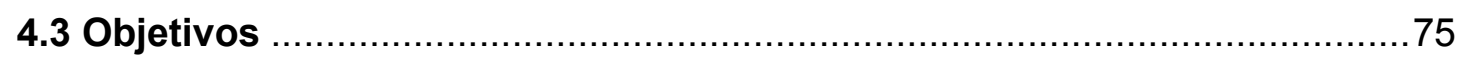

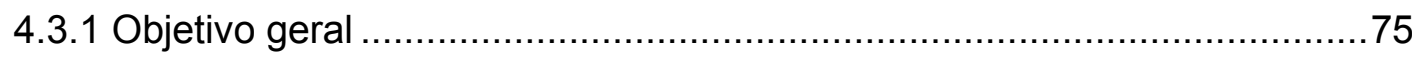

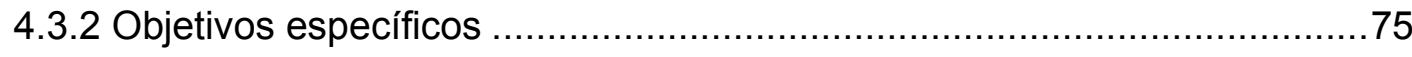

4.4 Procedimentos para a coleta e análise dos dados/informações ................76

4.5 Instrumentos

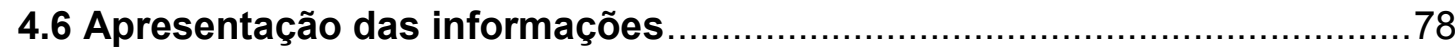

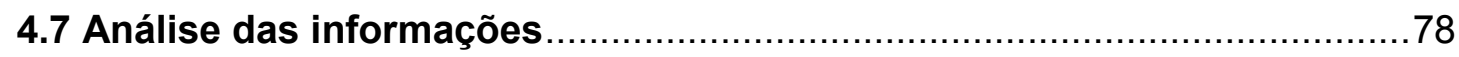

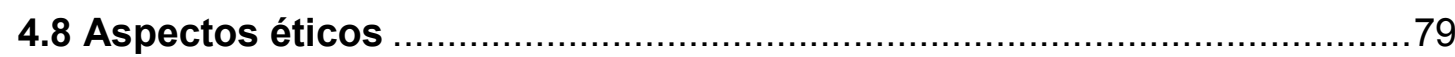

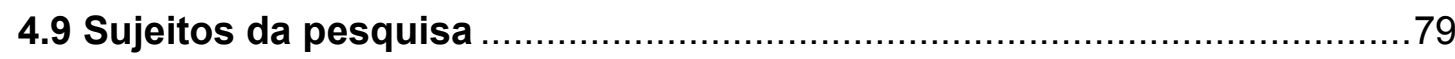

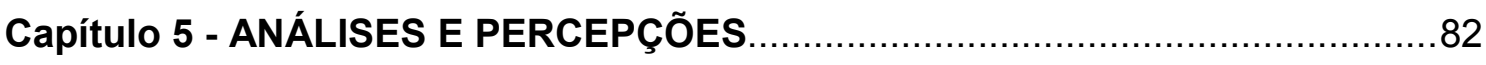

5.1 Análise de conteúdo: uma breve apresentação ..........................................82

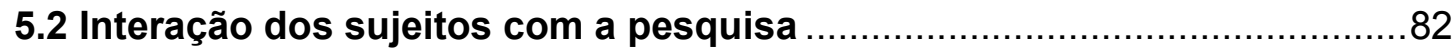

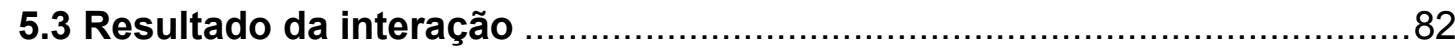




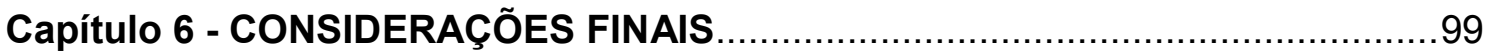

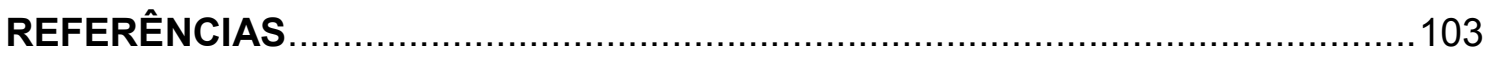

106

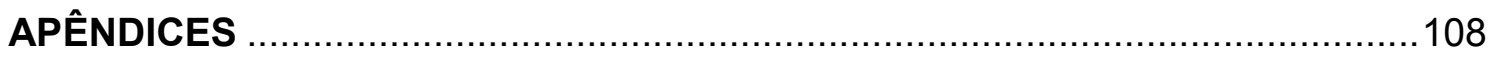




\section{INTRODUÇÃO}

Ao observarmos o homem ao longo de sua história podemos considerar que muitas sociedades se desenvolveram como "sociedades do conceito". Os conteúdos semânticos, ou seja, os significados dessas sociedades do conceito estabelecem (mas não determinam) os limites de articulação dos argumentos concretos que se podem construir em situações específicas.

Realizamos uma panorâmica histórico-filosófica para mostrar que as concepções de "dificuldade de aprendizagem e desenvolvimento" variam consideravelmente de época a época, assim como suas valorações positivas ou negativas. Entretanto, as formas de lidar com tais diferenças apresentam desconcertante constância na história que não se restringem ao âmbito apenas da Medicina ou apenas da Educação, mas que as duas esferas se encontram em diversos momentos da história e geram desdobramentos.

No primeiro capítulo, a partir do repertório teórico adotado (PESSOTI, 1984; REALE, 1991; PLATÃO, 1993; FONSECA, 1998; FOUCAULT, 2000; ARISTÓTELES, 1984, 2004; ARANTES, 2006), levamos em consideração a ontogênese e a filogênese do conceito de "dificuldade de aprendizagem e desenvolvimento". O levantamento histórico-filosófico constrói o percurso conceitual que nos demonstra com clareza as mais diversas formas de lidar social, religiosa, política e economicamente com aqueles que não se enquadram no padrão estabelecido como pertencente à normalidade - além de explicitar que padrões são esses.

No segundo capitulo, a partir das obras que nos serviram de apoio (ILLICH, 1975; BRUNI, 1989; FOUCAULT, 2000; GERALDI, 2001; MOYSÉS, 2001; NOVAES, 2001; TUNES, 2010; VILLAS BOAS, 2013), discutimos a relação entre Medicina e Educação que vem propiciando o surgimento de estudos e de discussões frequentes. Alguns males antes considerados médicos, hoje são objetos de estudos de diferentes áreas do conhecimento. Neste trabalho analisaremos a ideologia da medicalização, prescrita e defendida pela psiquiatria e que está relacionada com a educação. Também discutiremos o olhar que se tem sobre o aluno diagnosticado como apresentando supostos transtornos de aprendizagem.

Nesse processo, mostramos como uma educação como a exposta aqui revela a dificuldade da escola em lidar com o sujeito que não corresponde aos seus 
estímulos da forma esperada. Não sabendo como agir com situações consideradas diversas, a escola recorre à autoridade médica na busca por soluções que enquadram o sujeito como diferente dos demais. Dessa forma, acaba por patologizar a educação e determinar os caminhos a serem seguidos pelas instituições de ensino.

Assim, a escola se expropria de suas funções habituais e atribuições históricas, assim como da liberdade para exercê-las, em função da autoridade médica que dita às regras do que deve ser feito no trabalho com os sujeitos supostamente diagnosticados com transtornos de aprendizagem.

No terceiro capítulo, partimos de uma filosofia da singularidade (DELEUZE, 2006), para defender a ideia de que a simples noção de diferença só é capaz de se sustentar em uma cultura fundamentada na noção de homogeneidade ontológica do humano, como um fator da identidade hegemônica sobre as outras. Argumentamos, assim, que uma noção verdadeiramente inclusiva na escola (e além) só pode ser articulada pela noção de singularidade (entendida como o extremo da diferença que não pode ser reduzida, ontologicamente, a semelhanças). Retomamos, então, à questão da medicalização para mostrar como a adoção de uma nova perspectiva ontológica fundada na singularidade pode ensejar diferentes formas de se olhar para as diferenças concretas em sala de aula.

No quarto capítulo, fundamentado nas obras de Brandão, 1981, 2003, 2006; Flick, 2009; Creswell, 2010; MarconiARCONI \& Lakatos, 2011 apresentamos a metodologia que utilizamos para a produção das informações. Trabalhamos com a Metodologia Qualitativa, com abordagem na entrevista semi-estruturada que possibilita o envolvimento entre o pesquisar e os sujeitos da pesquisa por meio das falas significativas e, por último, a análise documental.

O desenvolvimento dessa pesquisa apontará caminhos para uma reflexão sobre uma alternativa para uma prática mais humanizada e humanizadora que respeite o ritmo, as habilidades e as competências de cada sujeito a partir de suas singularidades. 


\section{Capítulo 1 - A DIFICULDADE DE APRENDIZAGEM SOCIALMENTE CONSTRUÍDA}

\subsection{Introdução}

Desde muito cedo, em sua história muitos grupamentos humanos constituíram e se constituíram naquilo que poderíamos chamar de "sociedade conceitual", ou seja, uma sociedade que apoia seus princípios, crenças e posturas em elementos socialmente fundamentados e conceitualmente estabelecidos.

Pairando acima das concretudes particulares, essas sociedades do conceito estabeleceram os conteúdos semânticos que dão os horizontes hermenêuticos para além dos quais nenhuma mudança é possível, porque sequer pensável. Os conteúdos semânticos dessas sociedades do conceito estabelecem (mas não determinam) os limites de articulação dos argumentos concretos que se podem construir em situações específicas.

A situação não é estanque, evidentemente. Na relação dialética que se estabelece entre o conceito e suas concretizações em comportamentos sociais e vivências, há sempre transbordamento de ambos os lados. A vida, de modo geral, trazendo perturbação a um conceito que sempre se pretende estável; os conceitos e suas interconexões trazendo instabilidade à vida que se quer coerente $\mathrm{e}$ significativa. Daí, como foi dito, haver limitação mútua sem que haja determinação de lado a lado - uma subdeterminação, portanto.

Nesse sentido, não apenas a existência humana, mas a própria existência abstrata dos conceitos e suas interconexões se colocam no âmbito do devir, sob a égide da História. Não raro, posições que defendemos aqui e agora são tributárias de uma longa e complexa história pregressa, de desdobramentos insuspeitos para nós, mas que, independentemente de nosso conhecimento ou intencionalidade, delimitam nossas posições argumentativas.

Há, pois, quanto ao conceito, uma dupla perspectiva: uma "ontogênese do conceito", ou seja, uma maneira pela qual construímos nossas perspectivas sobre determinado assunto ao longo de nossa vida e, portanto, geralmente de modo consciente. Mas há também, sempre, uma "filogênese do conceito", que se dá ao 
longo de séculos, ou mesmo milênios, e da qual nem sempre, ou mesmo raramente, estamos cientes ${ }^{1}$.

Se a ontogênese do conceito está ligada à vida de um indivíduo particular, nas relações que estabelece a partir de sua existência no mundo, a filogênese do conceito está relacionada com a maneira pela qual aquele conceito desdobrou-se, alterou-se, ou sofreu deslizamentos em seus significados ao longo da História e do ponto de vista social.

A Filosofia se baseia em quatro pilares de análise pelos quais essa filogênese conceitual pode ser perscrutada (SOLOMON; HIGGINS, 2009): a Ontologia ou Metafísica, a Estética, a Ética e a Política. Não raro, conceitos que estão sendo articulados, aqui e agora, na esfera meramente política, passaram, em sua fundamentação filogenética, por construções relacionadas a um ou mais desses pilares: o ontológico, que afirma o que o objeto do conceito é; o estético, que afirma como o objeto do conceito aparece; o ético, que afirma como o objeto do conceito deve se comportar quando considerado no tecido social; e o político, que prescreve como o objeto do conceito deveria ser tratado quando considerado no tecido social. Mesmo quando não se está ciente desses pilares, é o uso deles que fornece validação conceitual aos comportamentos humanos no âmbito privado ou social ${ }^{2}$.

Desavisados dessa filogênese conceitual, arriscamo-nos a nos colocar no interior do próprio horizonte que deveríamos transcender. Arriscamo-nos, portanto, a simplesmente repetir e reforçar o que já está devidamente sedimentado no conceito vigente. Corre-se, então, o risco de naturalização do conceito ou das posturas que Ihe subjazem.

O conceito que desejamos considerar neste trabalho é aquele, especificamente, de "dificuldade de aprendizagem". Entretanto, neste capítulo estaremos considerando a perspectiva mais ampla, relacionada com o conceito de "dificuldade de aprendizagem e desenvolvimento", uma vez que, argumentaremos,

\footnotetext{
${ }^{1}$ Usamos os termos "ontogênese" e "filogênese" por empréstimo à Psicologia ou Biologia (FONSECA, 1998). Para melhor compreendermos o significado de filogênese e ontogênese nessas ciências, importa referir que a primeira se dedica ao estudo da evolução da espécie, a segunda ocupa-se do estudo da evolução de cada indivíduo desde o embrião até a velhice. Aqui se substitui a noção de indivíduo pela do significado individual do conceito e aquela de espécie pelos significados sociais compartilhados.

2 É essa perspectiva que permite eliminar o estranhamento com o surgimento de políticas, ao longo dos séculos, voltadas, por exemplo, para a escravidão de seres humanos, sem que ninguém, ou muito poucos, à época, as considerassem absurdas. Nunca o foram, a despeito de discordarmos de tantas. Estiveram sempre consideravelmente baseadas em uma ontologia, uma estética e uma ética que deram a essas políticas sua fundamentação racional.
} 
sua filogênese desenvolve-se a partir de tal imbricação - pela qual, por exemplo, muitas vezes se considera a dificuldade de aprendizagem como um "sintoma" de uma dificuldade de desenvolvimento subjacente.

Iremos dar contornos específicos acerca desse conceito mais amplo, mostrando como ele foi sucessivamente sofrendo deslocamentos de caráter ontológico e estético (e, portanto, também ético e político), ao longo da História do Ocidente. Mostraremos que as diferentes sociedades estabeleceram perspectivas muito diversas para esse conceito e constituíram, a partir daí, éticas e políticas muito específicas e historicamente datáveis relativamente a ele.

A partir dessa análise, esperamos esclarecer os fundamentos que sustentam a própria noção de "dificuldade de aprendizagem e desenvolvimento" atualmente em voga, suas origens histórico-filosóficas, e suas consequências éticas e políticas.

Em seguida, posicionaremos as atuais políticas e procedimentos direcionados à lida com os classificados como apresentando dificuldade de aprendizagem e desenvolvimento, agora de posse de suas fundamentações filogenéticas.

\subsection{0 conceito de "dificuldade de aprendizagem e desenvolvimento" e sua arqueologia}

Mesmo um breve levantamento histórico direcionado à investigação dos processos de exclusão permite constatar que a segregação e o enclausuramento foram, em todas as épocas, as políticas/ações mais utilizadas para lidar com aquele que era considerado "incapaz-de".

É, entretanto, interessante notar que as concepções de "deficiente" variaram consideravelmente de época a época, assim como suas valorações positivas ou negativas. A despeito de tal variação nas concepções, as formas de lidar com tais diferenças apresentam desconcertante constância na História.

De fato, ao longo da história da humanidade sempre existiram indivíduos com algum tipo de variação de suas características físicas ou cognitivas com relação à média estatística da sociedade em que habitavam. Tais indivíduos eram e ainda são considerados diferentes dos demais. Leia-se por diferente, por exemplo, o louco, o deficiente, aquele que não aprende, o extremamente sexualizado, o homoafetivo, o doente, o desviado, o alcoólatra, o desocupado, o que foge às regras e/ou aos 
padrões vigentes, entre outros. Essa diferença, de caráter inicialmente meramente estatístico, jamais se manteve assim, tendo sido valorada segundo diversos matizes ao longo de toda a História.

Conforme aponta Foucault (2000, p. 102):

Doentes venéreos, devassos, dissipadores, homossexuais, blasfemadores, alquimistas, libertinos: toda uma população matizada se vê repentinamente, na segunda metade do século XVII, rejeitada para além de uma linha de divisão, e reclusa em asilos que se tornarão, em um ou dois séculos, os campos fechados da loucura.

A seguir, defenderemos a ideia de que muito de nossas concepções e valorações, e, portanto, políticas, envolvendo a noção de "incapaz-de" se encontram historicamente fixadas por ideias de caráter ontológico, estético e moral, cujas raízes se originam na sociedade grega, no período Clássico, e vão se desenvolvendo e adquirindo novos realces ao longo da história cultural do Ocidente.

Assim, fazemos nas seções que se seguem, um estudo dessas ideias e de seus deslizamentos hermenêuticos ao longo da História, sempre tendo como fim a percepção da influência que estes tiveram para a concepção atual que temos de "incapaz-de".

Basicamente, o que se deve lembrar sempre é que o termo "incapaz-de" pede por um objeto direto como complemento, visto pressupor que o "incapaz-de" é sempre visto como incapaz de realizar algo. É esse algo que irá, em cada etapa da História Ocidental, dar os contornos ao conceito datado de "incapaz-de", aqui considerado especificamente como aquele que possui dificuldade de desenvolvimento e aprendizagem.

\subsection{Antiguidade Clássica: a eliminação do imperfeito}

$\mathrm{Na}$ Antiguidade Clássica, os considerados deficientes, de modo geral, eram rejeitados e/ou maltratados,

[Sócrates] - Portanto, estabelecerás na cidade médicos e juízes da espécie que dissemos; que hão de tratar, dentre os cidadãos, os que forem bem construídos de corpo e de alma, deixarão morrer os que fisicamente não estiverem nessas condições, e mandarão matar os que forem mal conformados e incuráveis espiritualmente.

[Trasímaco] - Parece-me que é o melhor, quer para os próprios pacientes quer para a cidade (PLATÃO, 1993, 410a). 
Ainda no mundo grego antigo, um exemplo de segregação, mais claramente de eliminação sumária, é o da sociedade espartana, militarista, que abandonava ou descartava as crianças que não consideravam perfeitas,

De todo modo, é sabido que em Esparta crianças portadoras de deficiências físicas ou mentais eram consideradas sub-humanas [elemento ontológico], o que legitimava sua eliminação ou abandono [elemento político], prática perfeitamente coerente com os ideais atléticos e clássicos [elemento estético], além de classistas [elemento ético], que serviam de base à organização sociocultural de Esparta e da Magna Grécia (PESSOTTI, 1984, p. 3).

Ainda que se possam encontrar exceções a esse tipo de comportamento, essa era a regra geral, uma vez que os interesses gregos daquele momento estavam prioritariamente voltados para a constituição da pólis perfeita e seus mecanismos de subsistência/sobrevivência (MARCONDES, 2002), não cabendo assim esforços para cuidar daqueles que virtuosamente não pudessem cooperar com a construção desse ideal.

Tais elementos ficam particularmente caracterizados nas filosofias dos dois principais autores do período: Platão e Aristóteles.

\subsubsection{Platão e a deficiência de recordações}

Esse ideal encontra concretização e fundamentação particularmente evidente na obra A República, de Platão (1993), que tem por finalidade precisamente dar as diretrizes para a construção do tipo de Cidade-Estado que mencionamos anteriormente.

Em Platão, surge uma relação íntima entre os conceitos morais e os conceitos estéticos (BASTOS, 1987), naquilo que ficou conhecida como sua doutrina da Kalokagathía (belo e bom). Criou-se, assim, uma relação imediata entre aqueles que apresentavam deformidades evidentes de formação física, por exemplo, e suas dimensões morais ${ }^{3}$. Menos evidentes seriam as conexões entre aqueles com dificuldades de aprendizagem e desenvolvimento e as referidas dimensões morais. Essas são esclarecidas pela epistemologia platônica.

\footnotetext{
3 Nas línguas isso ficou registrado pela maneira como nos referimos a ações morais: ações boas são
} "belas", etc. 
Já em $A$ República, Platão indica as ações a serem tomadas contra aqueles que são considerados inadequados para a construção da Cidade-Estado perfeita: o degredo, o abandono ou a morte.

Para além da questão puramente física, em toda a obra de Platão também se podem encontrar justificativas morais para problemas de ordem epistêmica e/ou cognitiva.

Platão, em muitas de suas obras recorre a mitos com poder propedêutico. Em A República, ele lança mão do chamado Mito de Er, pelo qual esclarece que aquilo que sabemos, de fato, é o que podemos recordar de nossas vidas anteriores ${ }^{4}$. Entre suas passagens sucessivas pelo mundo, a alma imortal deve beber das águas do rio Lethes (= esquecimento). Quanto mais ela beber das águas desse rio, mais esquecerá $($ aletheia $=$ não esquecimento $=$ verdade $)($ PLATÃO, 1993, Livro X). Os mais probos e virtuosos beberão menor quantidade dessas águas e esquecerão menos; os que apresentaram vícios e comportamento indigno na vida anterior beberão maior volume de água e, portanto, levarão uma vida seguinte com menor capacidade intelectual.

De fato, em sua obra Fédon (1972, p. 92-93), Platão associa alguns comportamentos ao retorno, na vida seguinte, na forma de um animal considerado inferior. Portanto, pode-se depreender da epistemologia platônica que aqueles que apresentam dificuldades cognitivas ou do que, modernamente, chamaríamos de dificuldades de aprendizagem ${ }^{5}$, têm a origem de seus males em uma vida pregressa má, dissipada por comportamento condenável. São, portanto, os principais responsáveis pela sua situação.

A posição de Platão se completa com o fato de que, pela própria estrutura do Mito de Er, não é possível alterar a condição de qualquer indivíduo ${ }^{6}$. Seu destino quanto às suas habilidades e, portanto, à sua participação nos estratos sociais de uma República perfeita, já está previamente traçado e nada pode ser feito para modificar essa sina. É assim que Platão pode defender, ainda em $A$ República

\footnotetext{
${ }^{4}$ Trata-se da teoria do conhecimento platônica. Dessa concepção decorre a noção de maiêutica, como sendo o conhecimento que se dá a partir de recordação.

${ }^{5}$ Em praticamente nenhum momento da História do Ocidente a pessoa possuidora de dificuldades cognitivas ou de aprendizagem foi objeto de análise. Em geral, as conclusões que podemos tirar sobre as consequências para portadores de dificuldades cognitivas das diversas filosofias são de caráter lógico, quando estendemos os preceitos destas filosofias para abarcarem também esses indivíduos.

${ }^{6} \mathrm{Um}$ argumento inatista, mas sem contornos biológicos.
} 
(1993, 433a) a noção de natureza humana: natureza do Guardião, natureza do Escravo, natureza do que não aprende, entre tantas,

[Sócrates] - Mas escuta a ver se eu digo bem. O princípio que de entrada estabelecemos que devia observar-se em todas as circunstâncias, quando fundamos a cidade, esse princípio é, segundo me parece, ou ele ou uma de suas formas, a justiça. Ora, nós estabelecemos, segundo suponho, e repetimo-lo muitas vezes, se bem te lembras, que cada um deve ocupar-se de uma função na cidade, aquela para a qual sua natureza é mais adequada (PLATÃO, 1993, 433a, grifo nosso).

Tal noção ontológica de natureza humana, mediadora do conceito moral de justiça, garante a racionalidade da ação política da manutenção de escravos, por exemplo, assim como do simples abandono a estratos mais modestos da Cidade àqueles que não são capazes de desenvolver suas qualidades intelectuais por terem bebido demasiado, em sua passagem transurânica, do rio do esquecimento. Ela também justifica a posição do filósofo como rei da cidade.

É possível depreender da obra de Platão, portanto, a acepção a ser dada ao conceito de "dificuldade de aprendizagem e desenvolvimento"7. Trata-se de uma deficiência de lembranças, de rememorações. O indivíduo é incapaz-de lembrar-se.

A teoria do conhecimento de Platão enseja ainda maiores consequências para os que apresentam tais deficiências. Como Platão defende a tese de que o mundo de nossa existência é reflexo de um mundo perfeitamente harmonioso, o mundo das ideias, ele precisa, evidentemente, justificar a existência do erro, do engano. Se há um mundo perfeito e um corruptível que se espelha no primeiro, a justificativa para a existência do segundo só pode estar no método de acesso ${ }^{8}$.

É nesse ponto que Platão reconfigura o problema eleático do Não-Ser. Para Platão, o Não-Ser equivale ao engano, à junção de conceitos na esfera da existência de maneira equivocada, que não espelha adequadamente a junção eterna e invariável que vale no mundo superior das ideias. A crítica de Platão se destina aos sofistas, principalmente desenvolvida na obra Sofista-poeta (PLATÃO, 1972a), aos

\footnotetext{
${ }^{7}$ Claramente, tal conceito sequer seria posto no interior da filosofia platônica, sendo substituído pelo conceito de "deficiência de rememoração".

${ }^{8}$ Essa problemática volta com força total na filosofia de Santo Agostinho, agora, entretanto, com a roupagem cristã. Retornaremos a ela mais adiante. De forma geral, qualquer abordagem que defina uma instância perfeita na qual outra imperfeita se espelha tem que associar os defeitos da última nos mecanismos de acesso à primeira. Em Platão trata-se de estabelecer a possibilidade do engano, ou o Ser do Não-Ser. Na esfera cristã, esse será o problema do Mal em um mundo criado por um Ser essencialmente Bom.
} 
quais ele atribui a posição mais baixa a ser ocupada na sua Cidade (PLATÃO, 1972, p. 471-472). O sofista-poeta, segundo Patão, é aquele que, intencionalmente, traz nas suas argumentações o Não-Ser e lhe dá aparência de Ser (PLATÃO, 1972, p. 193-203).

Ainda que, contrariamente ao sofista, aquele que apresenta dificuldade de aprendizagem e desenvolvimento não busque intencionalmente o engano (o NãoSer), ele é o candidato mais natural a concretizá-lo. Quanto maior a dificuldade, portanto, mais perigosa à cidade se torna a injustiça de colocá-lo em posições mais altas no estrato social. Esse deficiente platônico, um desmemoriado, traz para o seio da convivência social, pela sua natureza, o reino do Não-Ser e é o oposto do ReiFilósofo. Dado o seu perigo, é justo que seja segregado.

No Platonismo, assim como em todo o Cristianismo, a alma tem prevalência sobre o corpo, considerado, de fato, como sendo sua prisão. Assim, corpos com limitações são, ipso facto, prisões mais severas da alma e, de fato, no Platonismo, índices de algum tipo de maldade pregressa ${ }^{9}$, o mesmo ocorrendo para almas que apresentem limitações (quanto à cognição, por exemplo).

\subsubsection{Aristóteles e a deficiência de categorias}

Aristóteles, por seu turno, estabelece deslizamentos hermenêuticos importantes quanto às noções platônicas. De uma só vez, a doutrina aristotélica das Categorias (ARISTÓTELES. Categories, Physics. Book I, 3.5, 1984. p. 315-328) elimina $^{10}$ toda a teoria do conhecimento platônica, sua noção de natureza humana e também a ideia de "lugar natural" na sociedade ${ }^{11}$. Aristóteles, entretanto, é um biólogo, entre outras coisas, e interessa a ele classificar. Assim, em sentido similar, Aristóteles afirma que,

\footnotetext{
${ }^{9}$ Essa doutrina foi absorvida pela maioria das correntes Espíritas atualmente em voga, ainda que sob a égide do Cristianismo em que estão inseridas. No caso dessas correntes, trata-se de justificar a presença do Mal (da deformidade ou da cognição reduzida) mesmo naqueles considerados inocentes (recém nascidos, etc). Nesse caso, fica-se entre a assunção de que há o Mal originário no mundo, criado por um Ser essencialmente Bom (Deus) - o que relutam em aceitar -, ou presume-se que o Mal decorre de ausência de graça naquele afligido pelas deformidades (ver, mais adiante, a doutrina de Santo Agostinho). A doutrina da alma perpétua permite culpabilizar o próprio indivíduo pelos seus males, mesmo que recém-nascido, garantindo assim a bondade de Deus.

${ }^{10}$ A doutrina aristotélica das Categorias torna a doutrina platônica da rememoração, fundamento da epistemologia platônica, irrelevante e a substitui pelo hilemorfismo como fundamento.

${ }^{11}$ Curiosamente, Aristóteles ainda mantém a noção de "Lugar Natural" em sua filosofia natural ou física.
} 
[...] devemos estudar o homem que melhor apresente o melhor estado de alma e de corpo porque só nele encontraremos a verdadeira relação entre ambos; em indivíduos maus ou corrompidos, o corpo muitas vezes aparentará dominar a alma porque eles se encontram em condição ruim ou anormal (ARISTÓTELES, 2004, p. 150).

Desse modo, a doutrina da mens sana in corpore sano (PORTO, 1990), de sabor helênico-românico ${ }^{12}$, engendra um vínculo que, ao estabelecer um telos de perfeição, um ideal, ao mesmo tempo fornece as bases da segregação tanto daqueles que não apresentam uma exterioridade física perfeita, segundo os parâmetros da época, quanto daqueles que não apresentam plenos poderes cognitivos/mentais. Esses últimos não apresentariam, por razões que Aristóteles não explicita (mas que se pode supor serem de caráter biológico), a adequada compreensão e utilização das categorias de pensamento que ele elenca.

É interessante notar que Aristóteles não se opõe à existência do escravo, por exemplo, mas por razões já completamente distintas daquelas de Platão. Para Aristóteles o estado é superior ao indivíduo, porquanto a coletividade é superior ao indivíduo, o bem comum superior ao bem particular (ARISTÓTELES, 2004). Aristóteles não nega a natureza humana ao escravo, mas constata que na sociedade são necessários também os trabalhos materiais, que exigem indivíduos particulares, a que fica assim tirada fatalmente a possibilidade de providenciar a cultura da alma, visto ser necessário, para tanto, tempo e liberdade, bem como aptas qualidades espirituais. Daí a escravidão.

Aristóteles, portanto, defende ser a educação tarefa essencial do estado, que deve desenvolver harmônica e hierarquicamente todas as faculdades: antes de tudo as espirituais, intelectuais e, subordinadamente, as faculdades físicas. O fim da educação é formar homens mediante as artes liberais, sendo importantíssimas a poesia e a música ${ }^{13}$. Desse modo, deve-se relegar o trabalho manual aos que não for possível a aquisição dessas faculdades, e condizente com a posição social.

Inverte-se, pois, em Aristóteles, a direção do argumento relativamente a Platão. Ao invés de uma argumentação que vai da ontologia à ética e justifica a

${ }^{12}$ Esta é uma famosa citação latina, derivada da Sátira $X$ do poeta romano Juvenal (X. 365). No contexto, a frase é parte da resposta do autor à questão sobre o que as pessoas deveriam desejar na vida: "Deve-se pedir em oração que a mente seja sã num corpo são..." Interpretação mais atual dessa passagem pressupõe que só é possível ter uma mente sã em um corpo são, e vice versa.

${ }^{13}$ Aristóteles terá enorme influência na Baixa Idade Média, mais precisamente na Escolástica. Um dos grandes representantes de uma perspectiva de sabor aristotélico nesse período será São Tomás de Aquino. 
instância política do degredo, do abandono ou da eliminação baseados na natureza do indivíduo, como ocorre em Platão, tem-se uma argumentação que vai do político ao ético, ao se estabelecer os interesses do estado como sendo imperativos, justificando o degredo e a escravidão. Em uma direção ou outra, entretanto, os resultados práticos para os que apresentam dificuldades de aprendizado são relativamente os mesmos.

Platão e Aristóteles não são mencionados aqui por conveniência ou simplificação. Suas filosofias serão influentes na construção de toda a Filosofia Ocidental e dirigirão as formas pelas quais os conceitos em geral serão sucessivamente alterados pelas abordagens posteriores.

\subsection{A Idade Média (476 d.C.-1453 d.C.): o mal como ausência de bem}

Como veremos em seguida, muito da filosofia de Santo Agostinho, desenvolvida na Alta Idade Média (476 d.C.-1000 d.C.), pode ser compreendida como um novo deslizamento das perspectivas de Platão (ou seu continuador Plotino) de modo a compatibilizá-la com a perspectiva cristã.

Por outro lado, muito da filosofia de São Tomás de Aquino, desenvolvida na Baixa Idade Média (1000 d.C.-1453 d.C.), pode ser compreendida como deslizamentos das perspectivas de Aristóteles, também para compatibilizá-la com o cristianismo. Nosso interesse aqui é entender os deslocamentos sofridos pelo conceito de "dificuldade de aprendizagem e desenvolvimento" e adotaremos a obra de Santo Agostinho como emblemática da postura medieval.

\subsubsection{Santo Agostinho e a deficiência de iluminação divina}

A Idade Média é dividida em dois períodos distintos: a Alta Idade Média, que se inicia no século $V$ e está relacionada à Patrística, e a Baixa Idade Média, que se desenvolve desde o século VIII até o século XIV e está relacionada à Escolástica ${ }^{14}$.

\footnotetext{
${ }^{14}$ Há um interstício entre os dois períodos, geralmente considerado de pouco relevo pelos estudiosos por estar relacionado com uma atitude meramente de compilação do conhecimento anterior, ao invés de criação de conhecimento novo.
} 
Ambos os ciclos estão relacionados com o estabelecimento das bases do Cristianismo (BOEHNER; GILSON, 1970).

O principal filósofo cristão da Alta Idade Média, Santo Agostinho (2005), retoma as posições platônicas já mencionadas, mas com o filtro da filosofia de Plotino, naquilo que se convencionou chamar de neoplatonismo. Dentro dessa perspectiva, o mundo das ideias platônico é absorvido pela figura de Deus. Comparando-se essa nova perspectiva com o Mito de $E r$, já aludido, Deus passa a ser o centro da Verdade (dos arquétipos transcendentais e eternos) e é na relação entre Ele e os seres humanos que se dará a própria percepção das ideias e, finalmente, do próprio Deus. Essa percepção, portanto, se dá em virtude de uma iluminação divina e sobrenatural - um deslocamento hermenêutico da ideia de se beber das águas de um rio, consonante com as novas ideias cristãs.

Esse deslocamento hermenêutico, entretanto, não produz melhoria alguma na situação dos diferentes (feios/maus/tolos), pois Agostinho mantém a identificação entre o Bem e o Bom (agora sintetizados em Deus) e ainda acrescenta a questão da iluminação divina (a Graça) a permear a questão cognitiva. Para Agostinho, a variedade e diferenciação, físicas ou morais, se devem a uma privação de Ser, de Bem, de beleza, o que significa, para ele, a incidência do Mal (BASTOS, 1987, p $50)$.

Vimos que, no platonismo estrito, o sujeito desprovido de plenas capacidades cognitivas deveria ser considerado como alguém que por seus malfeitos em vida passada foi levado a beber mais do rio Lethes. Agora, no Cristianismo Patrístico, fortemente ligado ao Neoplatonismo, cabe compreender esse sujeito como desprovido da Graça ou Iluminação divina, estando em relação mais fraca ou inexistente com seu Criador. Ocorre, pois, um aprofundamento do problema ontológico-estético-moral relacionado com a dificuldade de aprendizagem e desenvolvimento, à medida que inclui um novo elemento de caráter religioso.

Como resultado dessas concepções, na Idade Média, os que se assumia terem dificuldades de aprendizagem e desenvolvimento viviam sob um conjunto de procedimentos que misturam o isolamento em locais determinados e as avaliações místicas (punitivas e segregadoras) próprias da época. De fato, por obra do universalismo cristão, mesmo aquele que supostamente apresenta uma dificuldade de desenvolvimento precisa ser assumido como humano e possuidor de uma alma; sua mera eliminação não é mais aceitável, de modo geral, como prática. Assim a 
custódia e o cuidado dessas pessoas passam a ser assumidos pela família e pela igreja, ainda que de maneira assistemática quanto ao acolhimento, proteção, treinamento e ou tratamento (FOUCAULT, 2000).

Mesmo no universalismo Cristão, entretanto, podem-se reconhecer situações em que a mera eliminação se tornou aceitável: as estruturas sociais eram definidas por leis divinas, sob o domínio da Igreja Católica, em que qualquer ideia ou pessoa que pudesse atentar contra esta estrutura teria de ser exterminada. A inquisição religiosa cumpriu à risca esse papel ao sacrificar como hereges ou endemoniados milhares de pessoas, entre elas loucos, adivinhos, alucinados e deficientes mentais.

Com a Reforma Luterana não houve progresso quanto ao tratamento dado aos imbecis, idiotas e loucos, uma vez que permaneceram sendo classificados segundo uma perspectiva ética fundada na culpa e na responsabilidade pessoal, como já vimos.

"Nestes, a concepção de deficiência variou em função das noções teológicas de pecado e de expiação. A explicação reside na visão pessimista do homem, entendido como uma besta demoníaca, quando lhe vem a faltar a razão ou ajuda divina" (PESSOTI, 1984, p. 12).

Ao longo de todo o período medieval, qualquer deformidade física ou mental/cognitiva continuava sendo um castigo associado ao pecado (CAVALCANTE, 2002), punível com o açoite, algemas ou mesmo a fogueira da Inquisição. Mesmo sob o ponto de vista dos médicos do período, a dificuldade de desenvolvimento é uma condição incurável, e o médico não deveria perder tempo ou reputação tentando curar o incurável (METZLER, 2006).

Entretanto, a diferenciar o período da Idade Média daquele do Classicismo Grego, pode-se citar que, com o advento do cristianismo e a visão de caridade e cuidado difundido pela religião, surge uma reflexão sobre o que fazer e como tratar os que não se desenvolvem: "a ambivalência caridade/castigo constituía a marca definitiva da atitude medieval diante da deficiência mental” (PESSOTTI, 1984, p. 6). Tem-se inicio o trabalho de construção de espaços destinados ao tratamento daqueles de quem se assumia uma dificuldade de desenvolvimento e aprendizagem.

Mesmo assim, segundo Granshaw e Porter (1989), os primeiros hospitais abrangiam quatro tipos de subdivisão: casas de leprosos, asilo de pobres, casas de repouso e instituições que tomavam conta de doentes pobres. As três primeiras 
divisões mostram que os hospitais da época serviam como uma forma de isolamento de pessoas que não eram desejáveis em meio à sociedade, incluindo entre elas pessoas com diversos tipos de dificuldade de desenvolvimento. Assim, o fato de a dificuldade de desenvolvimento ser tema de assistência religiosa não excluiu a visão negativa e contraditória que existia sobre o conceito.

\subsection{Idade Moderna: tratamento e controle}

$\mathrm{Na}$ Idade Moderna, em particular a partir do século XIX, o tratamento daqueles que apresentavam dificuldade de desenvolvimento sofreu uma sensível mudança do ponto de vista político-administrativo.

Por herança da Idade Média, os pobres, os enfermos, os incapazes, os marginalizados, começaram a ser vistos como seres humanos. Porém, seres humanos que necessitavam de controle, que deveria ser exercido pelo Estado. Esses espaços para o tratamento dessas pessoas vão ganhando, ao longo do tempo, diferentes nomes: manicômio, asilo, hospital, retiro, mas todos com a mesma finalidade,

O Retiro deverá agir como instrumento de segregação: segregação moral e religiosa, que procura reconstituir, ao redor da loucura, um meio tão semelhante quanto possível à comunidade dos Quacres. E isto por duas razões: a primeira é que o espetáculo do mal é, para toda alma sensível, um sofrimento, a origem de todas essas paixões nefastas e vivas que são o horror, a raiva, o desprezo, e que engendram ou perpetuam a loucura (FOUCAULT, 2000, p. 477).

Com a criação das instituições de tratamento e controle, os que apresentassem dificuldade de desenvolvimento e aprendizagem não estavam mais sujeitos às políticas adotadas na Antiguidade Clássica (eliminação) e na Idade Média (punições), já citadas neste texto.

A concepção da dificuldade de desenvolvimento e aprendizagem não estava mais atrelada ao que seria um mal metafísico. Estava naquele momento histórico sendo substituída por uma ideia de doença. Um mal físico e mental a ser reparado com tratamento e isolamento. É esse olhar da necessidade de cuidado (em busca da cura ou da separação da convivência com os demais) por parte do público e do privado que muda o tratamento da dificuldade de desenvolvimento e aprendizagem na modernidade. 
1.5.1 A sociedade burguesa e a deficiência de eficiência

Nos séculos XIV e XV, que marcam o final da Idade Média, se dá o aparecimento de uma nova camada social: a burguesia, capaz de sustentar financeiramente seus filhos nas instituições de ensino. As famílias burguesas passaram a enviar seus filhos para tais instituições e universidades, dando-lhes uma formação mais ampla ou técnica, geralmente voltada para áreas como a Medicina, a Arte, o Direito, a Filosofia ou a Arquitetura. A inserção dessa nova camada social nos meios escolares e sociais, entretanto, irá produzir inúmeras modificações nas estruturas de ambos os meios.

Na Idade Moderna há a consolidação da burguesia como nova classe social e a separação entre Igreja e Estado. Esse processo de consolidação da burguesia tem impactos importantes, uma vez que se passa a considerar dois núcleos fundamentais para a formação social do indivíduo: a família e a escola. Começa a se observar a questão das idades dos alunos, e são formadas "classes de idade" que já não misturam indivíduos de idades muito díspares para um mesmo aprendizado há a invenção da escolarização (a escola, na forma como nós a conhecemos atualmente, aparece no século XVII).

A importância da disciplina, herdada da Idade Média, é instrumentalizada e passa a servir ao novo objetivo imposto pelo olhar burguês: a eficácia relativa aos resultados. Junto a essa mentalidade voltada para os resultados, aparece a instituição "exame", que passa a permitir um controle não apenas da eficácia, mas também dos comportamentos, com a característica fundamental de ocorrer de forma impessoal,

\footnotetext{
A Idade Moderna, com a industrialização crescente, trouxe a partir do século XVII o conceito de "escola" e, portanto, "escolarização", em espaços próprios, organização do tempo, estruturação de programas, separação por idades, avaliação de desempenho e a orientação do desenvolvimento individual do aluno. Esta mudança visou à maximização da produtividade do processo ensino-aprendizagem, dentro duma filosofia caracteristicamente fabril e impondo definitivamente uma separação entre juventude (adolescência) e infância, com a obrigatoriedade da instrução destas duas faixas etárias (MATOS; RUDOLF, 2006, p. 9.93).
}

Começa a se formar na Idade Moderna um tipo mais abrangente de aluno, sem conotações religiosas, mas com características caras ao modelo burguês: o aluno adequado ao modelo deve ser capaz de absorver os conteúdos desenvolvidos 
com eficácia para que sua atuação na sociedade, agora considerada relativamente aos modos de produção desta, possa ser igualmente eficaz.

A noção de eficácia impõe ritmos particulares para os processos de ensino e aprendizagem que implicam, também, atitudes fortemente impactadas por uma abordagem disciplinar. Disciplina, entretanto, não engloba apenas a punição de comportamentos considerados contrários à moralidade vigente, mas também na rejeição de formas de ser que implicassem alteração menos eficaz, segundo o modelo burguês, de tais ritmos.

\section{Figura 1 - Propaganda da Prefeitura do Rio de Janeiro publicada no jornal 0 Globo em 7 de dezembro de 2014.}

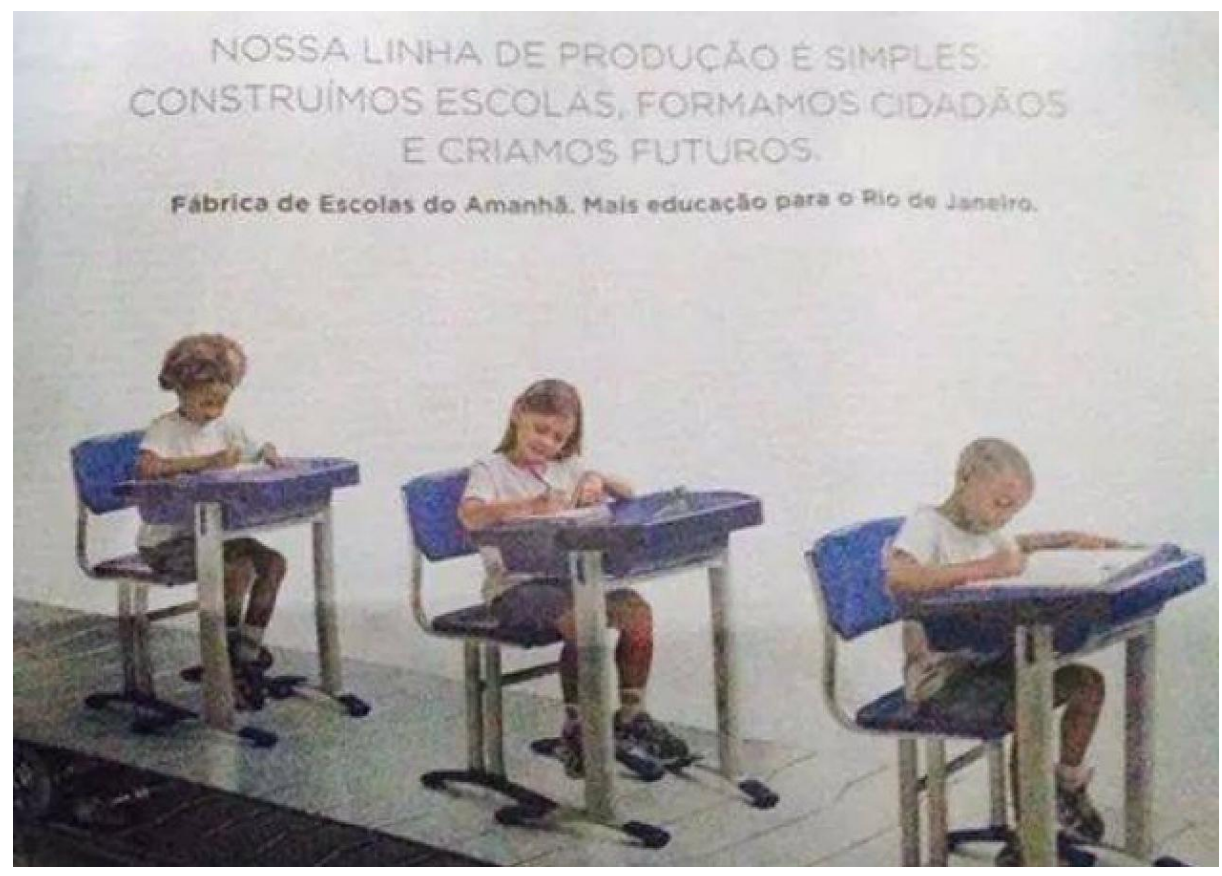

Fonte: Jornal O Globo, 7 dez 2014

Surge a ideologia medicalizante que será instrumental para estabelecer os contornos da deficiência que interessa ao Estado burguês, inclusive pela naturalização desses contornos e sua transformação em doença, síndrome ou transtorno. Sobre tal papel instrumental da ideologia da medicalização falaremos em outra oportunidade. 
Se há outro conceito que a Idade Moderna instrumentalizou de modo profundo é aquele de "tempo", inserindo-o em uma perspectiva de linha de produção (ver Figura 1), em que há a completa homogeneização das temporalidades em função da eficiência como um fim.

\title{
1.6 Idade Contemporânea: massificação e singularidade
}

$\mathrm{Na}$ contemporaneidade, ainda consoante ao modelo burguês, a educação busca a massificação. Após a Revolução Industrial (período entre os séculos XVIII e XIX) e a democratização de várias sociedades ao redor do mundo, a educação ganha um papel central na constituição diária das sociedades. A lógica da eficiência é mantida, agora remetida a uma realidade de caráter tecnológico que demanda indivíduos com alto grau de escolarização. O sistema social, portanto, sofreu modificações importantes que demandam novas formas de ensinar e verificar o aprendizado. Passa-se do chamado modelo do Fordismo (a linha de montagem pura e simples) para o Toyotismo (que exige a construção de um operário altamente qualificado) (MATOS; RUDOLF, 2006, p. 9.97).

A partir daí, a ideia de que a educação é para todos passa a ser difundida e estratégias para sua consolidação são criadas. Ao longo do período contemporâneo, a educação foi sofrendo modificações em programas e projetos até chegar ao momento atual,

\begin{abstract}
O final do século XIX e o século XX elegeram a educação como o principal motor de desenvolvimento dos países, pois só ela pode proporcionar a uniformização da cultura, capaz de moldar um padrão de cidadão e de sociedade, ao serviço de um Estado em vigência, isto é, guiado por certa ideologia política-religiosa-econômica. Ora, esta educação condicionada a objetivos institucionalizados é o que se denomina de "escolarização", porque a escola é o melhor instrumento, máquina ou aparelho que pode assegurar e otimizar a relação custo-benefício no alcance desses objetivos, acionada diretamente pelo centro de poder. Assim, a contemporaneidade tem sido marcada pelo aprofundamento dos dispositivos legais que visam garantir os limites de eficácia do processo de escolarização. Em vários países, têm sido propostas reformas educacionais, adaptações curriculares, planos de capacitação docente, procedimentos didáticos inovadores, etc., todavia, as modificações propostas não alteram as bases estruturais ou garantias de escolarização já lançadas desde o tempo dos colégios jesuítas (MATOS; RUDOLF, 2006, p. 9.97).
\end{abstract}

Note-se, porém, que "todos" não significa, via de regra, "indistintamente". "Todos" significa, muitas vezes, "todos aqueles que podem se adequar ao modelo 
imposto" ${ }^{15}$.Dessa forma, massificação, ao contrário do que pode parecer em um primeiro momento, não representa, necessariamente, inclusão.

Pode, eventualmente, representar a concretização de seu oposto. De fato, a massificação no ensino pode implicar construção de modelos estatísticos de verificação de aprendizagem. Somando-se a isso a perspectiva da medição de aprendizagem pela prova e de uma ideologia medicalizante, tem-se a possibilidade de se construir um modelo estatístico de normalidade - que rapidamente pode se converter em um modelo psicológico ou psiquiátrico de normalidade.

Seja como for, dadas todas as estratégias de modernização e as tentativas de melhoria ou avanço da proposta da escola, o marketing em torno da educação atual é que ela é mais humanizada, voltada para as relações professor-aluno e para o desenvolvimento integral do aluno. No entanto, o que vemos com alguma constância é ainda um modelo muito antigo, com exigências historicamente datadas, vestido em uma "roupagem" nova de elementos tecnológicos.

Com isso, a Idade Contemporânea é marcada por uma diversidade de lutas e buscas pelos direitos individuais. Mesmo tendo atravessado momentos históricos turbulentos, como duas Guerras Mundiais e tantos outros conflitos, é nessa fase da história que se começa a perceber o deficiente (aqui como diferente) como um sujeito de direitos (REALE, 1991). As relações sociais são diária e constantemente permeadas por tensões de toda ordem, resultando em acordos e desacordos sobre como a sociedade deve agir em relação a determinados problemas ou situações.

Entre outros fatores, o acesso mais universal à informação através dos meios de comunicação trouxe uma nova realidade para essa parcela da sociedade que enfrenta historicamente o preconceito e a exclusão (UNESCO, 2008). O ano de 1981 foi essencial para a popularização da ideia de inclusão e a divulgação dessa perspectiva em vários setores como transporte, acesso arquitetônico, educação, cobertura legal, dentre outros.

No Brasil, é somente a partir do século $X X$ que as políticas públicas e ações sociais começam a ganhar força na luta pelo reconhecimento da necessidade de assistência e inclusão para aqueles que eram considerados desiguais.

Nas décadas de 1960 e 1970, as Leis $n^{\circ}$. 4.024/1961 e no 5.692/1971 apresentaram artigos que discorriam sobre a educação do aluno considerado

${ }^{15}$ Lembremos: na democracia grega, por exemplo, todos os cidadãos gozavam de plenos direitos políticos; entretanto, nesta mesma democracia havia escravos (portanto, não cidadãos). 
especial. Embora esse tenha sido um indicativo de preocupação para com aqueles que aprendiam ou se desenvolviam de maneira diferente, nenhum dos referidos dispositivos legais retratou um avanço efetivo quanto ao cuidado específico para com o aluno com dificuldade de aprendizagem e desenvolvimento.

A ação efetiva quanto ao cuidado com pessoas consideradas com deficiência surgiu somente com a Lei $n^{\circ}$ 9.394/1996. Entretanto, essa lei em nada especifica ou explicita o cuidado com pessoas que apresentam dificuldades de aprendizagem e desenvolvimento.

Com o ensino especial parcialmente, ou discretamente, regulamentado (Lei $\mathrm{n}$. 5.692/1971), surgem salas de ensino especial, onde se iriam colocar em prática as ações necessárias para educar o considerado deficiente. Esses espaços serviam, como ainda hoje o fazem em muitas instituições de ensino, para segregar o diferente, o anormal, o diagnosticado, aquele que, enfim, não aprende como os demais ou, simplesmente, não aprende ${ }^{16}$.

A segregação acontece seja por este aluno ser tratado em ambientes supostamente preparados (salas especiais), especializados (salas de recursos), escolas especiais (Associação de Pais e Amigos dos Excepcionais - APAE, Pestalozzi, entre outras), por profissionais especializados (psicopedagogos, psicólogos, médicos, fisioterapeutas, terapeutas ocupacionais, fonoaudiólogos e professores supostamente preparados) etc.

Essas ações excluem (às vezes discretamente, outras vezes não) e, ao invés de se incluir o indivíduo levando em conta sua diferença, passa-se a vê-lo como possuidor de uma "patologia" que precisa ser tratada,

E a esperança de soluções desloca sujeitos sociais que, mais uma vez, submetem-se ao ritual da consulta, da anamnese, da memória que se expõe e mostra representações. São sujeitos especiais: a luz do diagnóstico que os focou já os ofuscou, com marcas de que pretendem se livrar. São sujeitos especiais que não se querem especiais (GERALDI apud MOYSÉS, 2001, p. 9).

A patologia em questão torna-se a identidade daquele sujeito. Descaracterizado de sua forma singular de identidade, é visto por aquilo que dizem que ele tem enquanto doença/patologia/enfermidade, ou por aquilo que dizem que

\footnotetext{
${ }^{16}$ Mas alguém, afinal, aprende como algum outro? Voltaremos a esse ponto no capítulo 3.
} 
ele não tem enquanto uma falta cognitiva, uma falta comportamental e/ou uma deficiência biológica.

\subsection{A dificuldade de aprendizagem como uma relação entre instâncias sociais}

A vantagem de se ter um olhar sobre diversas perspectivas relacionadas a um mesmo objeto é a possibilidade de, ao compará-las, poder compreender diferenciações que foram impostas pelos desdobramentos históricos e, principalmente, permanências. Assim, interessa-nos comparar as perspectivas que mencionamos anteriormente, sejam as impostas por filósofos, seja a imposta pela visão de uma classe e suas necessidades estruturais.

Ao compararmos todas essas abordagens, percebemos uma permanência particularmente importante. Em todas elas a dificuldade de aprendizado e desenvolvimento é sempre referida ao indivíduo, como se fosse uma propriedade sua e, portanto, do ponto de vista ético, também uma responsabilidade sua. Assim, diz-se muitas vezes que determinado indivíduo tem ou apresenta dificuldade de aprendizagem e desenvolvimento. Em Platão, esse indivíduo não possui memória suficiente (por ter bebido muito do rio Lethes); em Santo Agostinho, não possui iluminação suficiente (por não tê-la recebido de Deus); no período moderno, não possui uma temporalidade ou cadência suficiente (por apresentar uma síndrome ou uma doença).

Ao fazermos tal análise, conseguimos justamente fazer o transbordamento hermenêutico do conceito de dificuldade de aprendizado e desenvolvimento, nos moldes aludidos na introdução. Fazemos tal transbordamento precisamente mudando essa perspectiva geral que resvala no essencialismo (epistêmico, religioso ou biológico) ao considerar a dificuldade de aprendizado como uma relação.

Considerando-se a situação especificamente escolar, tratar-se-ia, portanto, de perceber que a dificuldade de aprendizagem seria uma relação entre o aluno e as necessidades impostas pela organização social, filosófica ou ideológica vigente (como os requisitos de ritmo, por exemplo), mediada primeiramente pela escola e, mais especificamente, pelo professor ou professores.

Essa mudança de perspectiva que propomos tem como primeira consequência a mitigação, se não a abolição, de uma ideologia medicalizante (que 
trataremos no capítulo seguinte), uma vez que, ao reportar a questão a uma relação, retira do indivíduo o protagonismo pelo fenômeno, dividindo-o entre os diversos atores envolvidos no processo de imposição do modelo vigente e no processo de mediação mencionados no parágrafo anterior.

Ao fazê-lo, aponta para a busca de soluções que precisam envolver (de fato) todas as partes da relação, em particular, no momento histórico atual, quanto às reconsiderações possíveis sobre os ritmos escolares e eventuais possibilidades de tornar mais flexível sua imposição.

Poder-se-ia dizer que tais ritmos não podem ser tornados flexíveis ao ponto de se fazer retornar ao aluno "com" dificuldades de aprendizado sua identidade e especificidade. $\mathrm{O}$ argumento poderia ser que, se a questão do ritmo é estrutural para a organização social vigente, então só se poderia mudá-la mudando-se tal organização.

Entretanto, é importante notar que, mesmo no âmbito de uma organização social burguesa já há diferenciações de ritmo das mais diversas maneiras, só que sempre direcionadas para as necessidades do sistema, e não para aquelas do indivíduo. Assim, sempre voltadas à uniformização dos ritmos relativos a um grupo ou subgrupo específico. As salas especiais já são algo próximo a isso, à medida que agregam aqueles alunos que, supostamente, possuem ou apresentam dificuldades, segundo a perspectiva que se quer aqui criticar.

$\mathrm{Na}$ verdade, tais espaços especializados cumprem função importante no modelo de escolarização burguês, à medida que permitem justamente isolar temporalidades distintas de modo a maximizar a eficiência relativamente ao modelo social. Salta aos olhos aqui, portanto, mais uma permanência que se faz notar entre os diversos exemplos apresentados: seja qual for o elemento coordenador das políticas e éticas subjacentes a um sistema, há sempre uma coordenação que ajusta o elemento educação às necessidades deste. Em todos esses casos, o que se viu até aqui foi a escolha por segregar o considerado deficiente (segundo o modelo social) de modo a educá-lo "dentro do possível", mesmo que isso implique relegá-lo desde o início, desde sua formação, a estratos menos significativos do modelo vigente (como escravo, como desgraçado ou endemoninhado, ou como trabalhador braçal). 
No capítulo seguinte iremos mostrar como a ideologia da medicalização foi instrumental para a imposição da noção vigente de dificuldade de desenvolvimento e aprendizagem. 


\section{Capítulo 2 - A MEDICALIZAÇÃO COMO INSTRUMENTALIZAÇÃO DA MEDICINA}

\subsection{Introdução}

Mostramos, no capítulo anterior, que as diferentes formas de pensar as pessoas sobre o ponto de vista ontológico, estético, ético e político engendram diferentes compreensões do que seja a dificuldade de desenvolvimento e aprendizagem. Apresentamos também a acepção específica advinda do surgimento da sociedade burguesa em seus dois momentos: o fordismo, mais ligado aos primórdios do desenvolvimento industrial e ao período moderno, e o toyotismo, vinculado a uma sociedade calcada na alta tecnologia no período contemporâneo.

A partir de suas próprias exigências estruturais, as diferentes formas de organização social humana não apenas estabelecem suas acepções, mas, também suas formas de justificação.

Neste capítulo discutiremos especificamente a medicalização, prescrita e defendida pela medicina psiquiátrica. Defenderemos que a medicalização, na sua relação com a educação, é uma ideologia decorrente da instrumentalização da medicina, fornecendo justificação ao modelo de eficiência e temporalidade vigente. Analisaremos, a partir daí, o olhar que se tem sobre o aluno a partir desse lugar criado e instituído pela medicina psiquiátrica.

\subsection{A medicalização}

A contemporaneidade desenvolve uma especificidade nos seus processos de autojustificação a partir do uso que faz da psicologia e, principalmente, da medicina psiquiátrica. Tal uso é referido como medicalização.

A medicalização não é apenas o ato de receitar medicamentos, que seria apenas $\mathrm{o}$ ato de medicar o sujeito ou o paciente. A ação de prescrever o fármaco para o paciente não é o foco da nossa análise, uma vez que em quase todas as áreas de atuação da medicina ao longo da história, remédios foram e são prescritos para o tratamento ou a prevenção de determinados males rotineiramente: 
cientistas aprenderam a extrair substâncias químicas diferentes desses materiais naturais. Eles estudaram os efeitos dessas substâncias sobre o corpo e viram quais doenças podiam tratar com esta ou aquela substância. Com essas substâncias químicas, criaram as drogas (ENCICLOPÉDIA ESCOLAR BRITANNICA, 2014).

Por sua vez, a medicalização, na sua articulação com a educação, é uma postura frente a diferenças de ritmo de aprendizagem que se apropria da psicologia ou da medicina psiquiátrica. Como postura, atinge a vida político-social em toda a sua plenitude, envolvendo principalmente o imaginário daqueles que estão relacionados com a situação ou o problema em questão. Trata de estabelecer vínculos entre a noção de doença e as subjetividades que não atendem ao princípio dominante de temporalidade:

\begin{abstract}
A medicina moderna, se de um lado e como discurso dominante, afirma-se capaz de curar e prevenir as doenças (pois tem o poder de intervir e dirigir os processos biológicos do homem), não consegue mais ignorar que só isto (o que verdadeiramente não é pouco) não será suficiente para realizar os objetivos que anuncia. Mas, justamente pela sua forma de articulação social, refletida no seu corpo conceitual, não tem como pensar o biológico e o subjetivo historicamente, a não ser de forma desarticulada (NOVAES apud MOYSÉS, 2001, p. 153).
\end{abstract}

Assim, a medicalização se coloca para além da proposta original da medicina, ao não propor cura alguma para os supostos males que diz tratar, mas sim o controle do sujeito a partir dos instrumentos que possui para realizar tal controle: "A extensão do controle profissional a cuidados dispensados a pessoas em perfeita saúde é uma nova manifestação da medicalização da vida. Não é preciso estar doente para se transformar num paciente." (ILLICH, 1975, p. 47). Nesse sentido, a medicalização não é apenas uma perversão da educação, quando aplicada a esta, mas também e originalmente da própria medicina.

\title{
2.3 A ideologia da medicalização: remédios que fazem aprender
}

Nos últimos vinte anos, a sociedade em geral, mas principalmente os estudiosos da educação e da saúde viram surgir um aumento demasiado de diagnósticos de transtornos de aprendizagem acompanhados de receitas médicas em todo o mundo. Essa realidade se difundiu nos Estados Unidos da América (EUA) e em países europeus, mas não tardou a se fazer presente no cotidiano brasileiro. 
A escola brasileira já lidava com os alunos com diagnósticos e laudos, pois essa não é uma realidade recente. Porém, a partir da Lei N. 9.394/1996, a escola viu-se obrigada, agora juridicamente, a desenvolver estratégias para lidar com as exigências legais, direcionadas ao trabalho pedagógico com os alunos que supostamente apresentam necessidades especiais.

Ficou por se dizer como seria estabelecida essa fronteira entre alunos que apresentam e alunos que não apresentam necessidades especiais - um critério, portanto. Fronteira tênue, claramente multicausal, mas que precisava ser objetivada pela escola, na sua busca pelo atendimento da Lei.

É nesse ponto que os diagnósticos se fazem úteis para pôr em prática esse tipo de estratégia, uma vez que dão ao processo de seleção ao menos a aparência de cientificidade e, portanto, objetividade.

Entretanto, o fenômeno da dificuldade de aprendizagem, em sua concretude, mantém-se recalcitrante quanto às pretensas objetivações diagnósticas. $O$ diagnóstico, correto ou não, cumpre a função de dar relevo a apenas um dos agentes (ou pacientes) no problema das dificuldades de aprendizado - precisamente os alunos - retirando o peso e a responsabilidade dos outros agentes (escola, família etc.) em todo o processo.

Há ainda algo de perverso na junção entre a abordagem diagnóstica e o modelo que vem sendo usado por algumas escolas, para lidar com a questão dos alunos que recaem sob seus rótulos. O uso de avaliações diferenciadas, que são meramente avaliações com grau extremamente simplificado, tende a produzir um efeito largamente conhecido na Psicologia como Profecia Autorrealizadora.

Os alunos rotulados pela abordagem diagnóstica terminam por receber tratamento tão imbecilizante, que, ao cabo de pouco tempo, estão em situação de desenvolvimento cognitivo que tende a confirmar o diagnóstico - nesses casos, o diagnóstico, e as práticas que ele põe em movimento, terminam por ser a causa da verificação a posteriori do próprio diagnóstico! A verdade do diagnóstico, elemento último do processo de verificação a posteriori, é, pois, ao menos nesses casos, uma instância particularmente perversa da estrutura circular da Profecia Autorrealizadora que, assim exposta, explicita a dimensão da construção social dessa verdade ${ }^{17}$.

\footnotetext{
${ }^{17}$ Há aqui paralelos óbvios com outros tipos de Profecias Autorrealizadoras. Para citar um exemplo, a perspectiva que defende a diferença dos poderes cognitivos como sendo o resultado de diferenças raciais (e.g, que negros são menos capazes que brancos) por muito tempo assentou em
} 
É neste ponto, com a entrada em cena dos diagnósticos médicos (consultas, exames e receituários de medicamentos controlados para o tratamento de dificuldade de aprendizagem, comportamentos indesejados e dificuldade de socialização) e psicopedagógicos (acompanhamento, terapia psicológica, terapia ocupacional), que finalmente se estabelece uma conexão constante entre a escola e a Medicina. É nesse contexto que a visão medicalizante vem ganhando força na sociedade:

E os diagnósticos que justificam os encaminhamentos, seja da escola para a unidade de saúde, seja do pediatra para o especialista, como tendem a não ser diagnósticos, mas rótulos, modificam-se ao sabor da moda. Ou, mais precisamente, em decorrência da via de acesso disponível no momento (MOYSÉS, 2001, p. 68).

Ao papel meramente pedagógico (equivocado) das provas diferenciadas, ao menos na forma como são em geral pensadas e aplicadas, adiciona-se agora um elemento externo ao contexto pedagógico, com poderes ainda maiores, no processo de autoverificação a posteriori.

Assim, por exemplo, um aluno que considere as estratégias de ensino de uma escola insuportavelmente tediosas e que se inquiete com isso, emitindo comportamentos julgados perturbadores da normalidade das aulas (seus ritmos), pode ser rotulado (diagnosticado) como hiperativo ou com transtorno de oposição e receber "tratamento adequado" à situação.

Com a ingestão de medicamentos, e a eventual prostração que disso advém, as inquietações do aluno são abafadas e ele termina por se ajustar às mencionadas estratégias de ensino. A ele é aplicada uma prova diferenciada com exigências mínimas e suas notas melhoram. "Verifica-se", portanto, a posteriori, que o aluno de fato foi corretamente diagnosticado, visto que o remédio tomado "resolveu o problema". O aluno, portanto, estava no fundamento do problema, e não as estratégias da escola, pois foi a sua medicação que o resolveu.

Note-se que alguns alunos apresentam reações muito diferentes das esperadas pela interferência médica, a despeito do que se quer ver como resultado positivo da medicalização do ensino. Esses alunos podem apresentar letargia,

procedimentos que, por tomar esse "diagnóstico" como apropriado, propiciava aos alunos negros piores condições de aprendizagem. Com isso, tais alunos terminavam por fracassar ali onde alunos brancos foram bem sucedidos, reforçando a crença em um fenômeno que, por fim, foi ela mesma a causadora. 
desânimo, sonolência e outros sintomas derivados do uso da medicação. Mas tais sintomas, por não serem os esperados, muitas vezes são desconsiderados pela instituição que vê na intervenção médica o resultado para os problemas "dos alunos", quando na verdade foi apenas o seu problema que foi "resolvido".

A força impressionante desse novo modelo de autoverificação baseado na perspectiva da medicalização decorre de ele estar ligado às dimensões fisiológicas, vinculadas às dimensões psíquicas (e, portanto, comportamentais) do indivíduo. A força da objetivação, que o processo de verificação a posteriori pela medicalização enseja, é tremenda. Muito maior do que aquela haurida das estratégias meramente pedagógicas (como a da prova diferenciada), sujeitas a questionamentos relativamente triviais. A diferença é que no processo que envolve a medicalização, todo um novo corpus de conhecimento está envolvido (no caso a Medicina), tornando o questionamento muito menos óbvio.

A relevância da investigação da relação existente entre a medicina psiquiátrica e a escola decorre da possibilidade de se compreender adequadamente suas consequências para a vida e a educação das crianças em idade escolar, uma vez que rótulos e etiquetas, tidos como diagnósticos ${ }^{18}$, podem levar a tratamentos às vezes desnecessários e abusivos.

A necessidade do acompanhamento/tratamento e/ou da medicação não é um ponto a ser definido aqui como pontualmente maléfico, mas um item a ser investigado e decidido com cautela pela família da criança. A intenção deste estudo é oferecer um horizonte de reflexões acerca do tema.

No que se refere à medicalização das crianças em idade escolar, as estatísticas mostram (MEIRA, 2011) que o número de crianças medicadas ou em "acompanhamento/tratamento" cresce a cada ano. O Brasil não está fora dessas estatísticas. Uma das queixas mais frequentes apresentadas pelas famílias e pela escola, na busca por uma solução e/ou ajuda, é a de que a criança não aprende ou que ela não tem um comportamento normal.

Uma alternativa para o despreparo da família e da escola em lidar com questões sociais e/ou comportamentais da criança é a busca pelo atendimento

${ }^{18}$ A documentação produzida pela medicina psiquiátrica, amparada muitas vezes pela psicologia, e, não raro, sem bases em exames laboratoriais, sem comprovações específicas, que ficam a cargo da lista de supostos transtornos descrita nos "DSMs" e em que a Escola e a Família se baseiam para "tratar" e "educar" o sujeito em questão. 
médico especializado, que diga o que a criança tem ou não tem, pois tanto a falta quanto o excesso são problemas a serem resolvidos; que a diagnostique e que aponte posturas a serem assumidas no trato com aquele pequeno paciente:

A consulta médica pretende ser, na atualidade, um dos principais elementos para a identificação de crianças que não conseguirão aprender-na-escola. É, costumeiramente, a partir da consulta que as crianças se tornam reféns de uma incapacidade cientificamente atestada. Reféns do fracasso, reféns de uma doença que as torna incapazes (MOYSÉS, 2001, p. 62.).

Se a criança não consegue aprender ela é sinônimo de fracasso e o fracasso de quem não aprende é exposto via ambiente escolar. O fracasso escolar é um problema que gera muitas discordâncias ao ser discutido. A maior delas está em achar os seus responsáveis. A ideia de não responsabilização permeia toda a esfera que envolve a escola. A família não quer ser sujeito desse fracasso, o aluno não pode e não deve (ou não deveria poder) ser esse assujeitado, a escola isenta-se desse papel e o governo alia-se à escola nessa postura:

Do mesmo modo que todos referem causas centradas na criança, todos referem problemas biológicos como causas importantes do não aprender na escola. $\mathrm{Na}$ opinião destes profissionais, os problemas de saúde das crianças constituem uma das principais justificativas para a situação educacional brasileira (MOYSÉS, 2001, p. 29).

Para que esses entraves sejam diminuídos e administrados, a escola, juntamente com a Medicina, e, por vezes, aliada à família, encontra na criança características não condizentes com as exigências do sistema, mas as identificam como características não condizentes com a escola, qualquer que esta seja.

Essa "falta" ou esse "excesso" apresentado pela criança precisa ser administrado, tratado e/ou medicado para que ela venha a se encaixar "nos padrões ou ritmos normais". Isso, supostamente, garantiria a ela melhores condições de convivência, encaixe social e êxito escolar:

Com o consentimento da sociedade, que delega à medicina a tarefa de normatizar, legislar e vigiar a vida, estão colocadas as condições históricas para a medicalização da sociedade; para nosso objeto, mais especificamente, a medicalização do comportamento e da aprendizagem (MOYSÉS, 2001, p.171). 
Faz-se necessária uma reflexão sobre essa perspectiva. Uma criança rebelde, agitada, inquieta precisa ser tratada como diferente a ponto de ser encaminhada ao serviço de atendimento médico para ser diagnosticada e medicada ${ }^{19}$ ? Qualquer um que conheça o rol de características que o Manual Diagnóstico e Estatístico de Transtornos Mentais V (DSM-V, do inglês Diagnostic and Statistical Manual of Mental Disorders) elenca para várias síndromes ou transtornos sabe que a terminologia é bastante sujeita a diferenças de interpretação e aplicação - pululam termos como "muitas vezes", "frequentemente".

De fato, crianças com deficit de atenção e hiperatividade:

são consideradas, com frequência, crianças com um temperamento difícil. Elas prestam atenção a vários estímulos, não conseguindo se concentrar em uma tarefa única e, assim, cometendo erros muitas vezes grosseiros. É comum terem dificuldade para manter a atenção, mesmo em atividades lúdicas e com frequência parecem não escutar quando chamadas. Muitas vezes não conseguem terminar seus deveres escolares, tarefas domésticas ou deveres profissionais (GALVÃO, Ana Luiza; ABUCHAIM, Cláudio Moojen. abc da saúde, [s.d.], grifo nosso)

A dislexia do desenvolvimento é considerada um transtorno específico de aprendizagem de origem neurobiológica, caracterizada por dificuldade no reconhecimento preciso e/ou fluente da palavra, na habilidade de decodificação e em soletração. Essas dificuldades normalmente resultam de um déficit no componente fonológico da linguagem e são inesperadas em relação à idade e outras habilidades cognitivas. (<http://www.dislexia.org.br/>. Acesso em: 6 jun. 2015).

A discalculia é considerada:

um problema causado por má formação neurológica que se manifesta como uma dificuldade no aprendizado dos números. Essa dificuldade de aprendizagem não é causada por deficiência mental, má escolarização, déficits visuais ou auditivos, e não tem nenhuma ligação com níveis de QI e inteligência. Crianças portadoras de discalculia são incapazes de identificar sinais matemáticos, montar operações, classificar números, entender princípios de medida, seguir sequências, compreender conceitos matemáticos, relacionar o valor de moedas entre outros. (MORAES, Paula Louredo. Brasil escola. [s.d.], grifo nosso)

19 Entretanto, repetimos aqui, em outras palavras, que o intuito desse estudo é levantar reflexões e não determinar o fim da prática do acompanhamento médico e psicopedagógico, mas entender todos os vieses desse panorama mundial. 


\section{A síndrome do pensamento acelerado:}

é uma condição moderna que tem origem com o ritmo alucinante das grandes cidades, com overdoses diárias de informações e obrigações que afetam a saúde emocional de uma boa quantidade de gente. [...] Especialistas dizem que a síndrome do pensamento acelerado não é uma doença, mas sim um sintoma vinculado a um quadro de transtorno de ansiedade. As pessoas mais vulneráveis geralmente são aquelas que são avaliadas constantemente por conta das suas obrigações profissionais, não podendo desligar um minuto sequer, caso contrário o trabalho é comprometido. Bons exemplos são executivos, jornalistas, escritores, publicitários, professores e profissionais da saúde. (contioutra.com, 2015, grifo nosso)

O Transtorno do Espectro Autista é definido pela presença de 'déficits persistentes na comunicação social e na interação social em múltiplos contextos, atualmente ou por história prévia', de acordo com o DSM-V. Como a Síndrome de Asperger só foi reconhecida recentemente como um transtorno do espectro autista, o número exato de pessoas portadoras da doença ainda não é exato. Estimativas mostram que a ocorrência do transtorno pode ser mais comum do que se acreditava: uma entre 250 crianças aparentemente são diagnosticadas com a síndrome. Outros números dos Estados Unidos mostram que a incidência da doença pode ser bem menor (uma em cada dez mil crianças, aproximadamente). [...] A causa exata da Síndrome de Asperger, assim como do Transtorno do Espectro do Autismo, ainda não é conhecida. Os cientistas, por outro lado, acreditam que uma anormalidade no cérebro das crianças portadoras seja a causa mais provável. (VINOCUR, Evelyn (Rev.), [s.d.], grifo nosso)

Quando o comportamento de uma criança é frequentemente rebelde e desafiante, ela pode ser diagnosticada como sendo portadora do Transtorno Opositivo-Desafiante. [...] Os "critérios diagnósticos" para o TOD definido pelo Manual de Diagnóstico da Associação Americana de Psiquiatria (DSM-IV TR): a criança apresenta um padrão de comportamento negativista, hostil e desafiante que dure, pelo menos, 6 meses, durante o qual 4 ou mais dos sintomas abaixo estão presentes: muitas vezes perde a calma; frequentemente discute com adultos; muitas vezes ativamente desafia ou se recusa a cumprir as regras ou comandos dos adultos; muitas vezes incomoda as pessoas deliberadamente; muitas vezes culpa os outros por seus próprios erros ou mau comportamento; é suscetível ou facilmente aborrecido pelos outros; frequentemente apresenta raiva e ressentimento; frequentemente é rancoroso ou vingativo. Pelo que podemos concluir, uma criança com TOD é uma criança mal-educada, respondona, metida, birrenta e rebelde. (http://transtornosdeaprendizado.com/crian a desafiante, Acesso em: 5 jun. 2015, grifo nosso).

Sérias violações de regras, como fugir de casa, não comparecimento sistemático à aula e enfrentamento desafiador e hostil com os pais também são sinais da doença. Esse transtorno está frequentemente associado a ambientes psicossociais adversos, tais como: instabilidade familiar, abuso físico ou sexual, violência familiar, alcoolismo e sinais de severa perturbação dos pais. (...) O tratamento dos transtornos de oposição e de conduta envolve principalmente psicoterapia individual e familiar, e às vezes reclusão em unidades corretivas. (GALVÃO, Ana Luiza; ABUCHAIM, Cláudio Moojen. abc da saúde, [s.d.], grifo nosso). 


\subsection{A medicalização e a contemporaneidade}

Com os aparatos que a medicina possui: respeitabilidade histórica, legitimidade técnica, abrangência social e política, a medicina psiquiátrica institui o transtorno a partir de características que ela própria elenca no comportamento dos sujeitos, no intuito de enquadrar pessoas e consequentemente medicá-las.

A psiquiatria, portanto, constrói seus transtornos e prescreve seus diagnósticos. Conta, além disso, com a possibilidade sempre presente da autoverificação a posteriori, já mencionada na seção anterior. Por isso, neste texto, nos referiremos sempre a estes males da saúde como "supostos transtornos", pois esta ideia traduz o pensamento reflexivo que tentamos produzir com esta abordagem - reflexivo, por exemplo, no sentido de jamais considerar um efeito concreto da medicação como sendo uma óbvia prova de sua adequação.

O elemento crucial para a efetiva materialização do diagnóstico é a aceitação social que a psiquiatria possui como área da ciência responsável por curar os males internos que afligem o homem:

\footnotetext{
A instituição médica é uma empresa profissional, tem para matriz a ideia que o bem-estar exige a eliminação da dor, a correção de todas as anomalias, o desaparecimento das doenças e a luta contra a morte. Reforça os aspectos terapêuticos das outras instituições do sistema industrial e atribui funções higiênicas subsidiárias à escola, à polícia, à publicidade e mesmo à política. O mito alienador da civilização médica cosmopolita chega assim a se impor bem além do círculo em que a intervenção do médico pode se manifestar (ILLICH, 1975, p. 102).
}

Essa materialização do diagnóstico acontece quando a psiquiatria, por meio de seus aparatos, destitui do sujeito sua identidade, materializando, tornando real através de análises, estudos e discussões aquilo que se quer ver enquanto falta neste outro. Essa aceitação por parte da escola possibilita à ciência médica o estabelecimento de conjuntos de posturas e comportamentos ditos normais, assim como, também, a listagem daquelas posturas e comportamentos que estão fora dos padrões considerados dentro da normalidade.

Os comportamentos e posturas que não se enquadram nos padrões da normalidade médica, tornam-se culturalmente os mesmos que não se encaixam na normalidade social. Dessa forma, uma esfera da vida complementa a outra com 
seus critérios de avaliação do comportamento e da conduta humana tendo como critério a normalidade:

Ao ser historicamente instituído na cultura como um modo de afirmação da normalidade e de negação da diversidade, o conceito de deficiência tem em seu núcleo o preconceito: a afirmação do Outro como possuidor da deficiência ocorre em referência a um Eu, possuidor da normalidade (TUNES, 2010, p. 19).

Assim, o conceito de normalidade dita as regras. É esse conceito que afirma o que deve ser considerado padrão dentro e fora da escola, delegando àquele que não se encaixa nesses padrões o lugar da estranheza, da diferença, da anormalidade.

\subsection{A medicalização e a escola}

A escola, por sua vez, vive entre as duas esferas (a vida social e a ciência médica) e está totalmente influenciada por elas. Mas a escola não é passiva no processo de medicalização e também contribui para a construção social e a efetivação diária da medicalização da vida do sujeito que está inserido no meio educacional.

De fato, a escola atual está inserida em uma perspectiva de busca pela educação em massa, capaz de atender a um número de alunos que cresce incessantemente. Dessa forma, busca uma educação homogênea e de fácil aplicação à maioria dos alunos, e termina por não saber lidar com as diferenças de aprendizagem que seus alunos apresentam.

Assim, parte em busca de soluções para um "suposto" problema físico, biológico, psicológico ou comportamental que deve ser resolvido por uma autoridade (externa ao ambiente pedagógico) que se propõe a resolver os infortúnios existenciais da vida humana: a medicina psiquiátrica com suas resoluções medicamentosas.

O entrelaçamento da medicina com a escola alçou as "supostas dificuldades de aprendizagens" ao patamar de doença, como se depreende facilmente das citações anteriores sobre transtornos e deficit.

Essa caracterização deu o direito à medicina psiquiátrica de medicar a educação, numa tentativa de controle social daquilo que é considerado um entrave 
político e social para o desenvolvimento da proposta da escola. Crianças que não conseguem sucesso dentro dessa proposta apresentam um problema a ser resolvido e a escola recorre à psiquiatria para ajudá-la. Essa estratégia de ação torna a vida do sujeito objetivo de análise, de verificação, de estudo e, finalmente, de diagnóstico.

Com a produção do diagnóstico, a materialização da medicalização está pronta. O sujeito que apresenta o suposto transtorno de aprendizagem é agora rotulado, excluído, marginalizado, medicado e visto sobre o olhar do "diferente".

Esse olhar relativo ao diferente produzido pelo diagnóstico retira do sujeito singularidade a partir de uma normatização de sua identidade, sua humanidade, caracterizando-o como o "portador" do suposto transtorno de aprendizagem. O sujeito tem retirado de si, quase que sequestrado, nome e sobrenome e, a partir de agora, não se tem mais o sujeito, mas em seu lugar, o portador do diagnóstico: ele passa a ser o aluno disléxico, o aluno TDAH, o aluno autista, o TOD, entre tantos outros transtornos que estão inseridos no mais novo DSM V (APA, 2014).

Com a perda da singularidade para o diagnóstico, o sujeito tem sua autonomia expropriada de si em razão da suposta doença que apresenta e sente ser retirada de si, paradoxalmente, sua identidade por não ser igual aos demais:

E a esperança de soluções desloca sujeitos sociais que, mais uma vez, submetem-se ao ritual da consulta, da anamnese, da memória que se expõe e mostra representações. São sujeitos especiais: a luz do diagnóstico que os focou já os ofuscou, com marcas de que pretendem se livrar. São sujeitos especiais que não se querem especiais (GERALDI apud MOYSÉS, 2001, 9).

Este é um momento crucial no processo de medicalização. A perda da singularidade que sua identidade estabelecia, antes de tudo, é a perda da autoridade sobre si. Esse é um aspecto de difícil aceitação, vivência e compreensão. É aceitar que o outro não só diga quem você é, mas como você deve ver a si mesmo. 


\subsection{A medicalização e o sujeito}

A percepção de si é outra nuance da relação medicalização-escola que apresenta problemas sérios: a visão sobre si mesmo que o sujeito diagnosticado desenvolve a partir do diagnóstico e do olhar do outro que o vê:

No limite, o estigma criado por quem exclui é assumido por quem é excluído, havendo o risco de se fechar o círculo de separação e até mesmo de ruptura de identidade, de expectativa, e isso, sem dúvida, é algo gravíssimo (TUNES, 2010, p. 22).

Para além da ideia de que esse ou aquele sujeito apresenta o suposto transtorno de aprendizagem, estão as avaliações informais que são realizadas pelas pessoas de seu convívio diário e que são conhecedoras do diagnóstico.

Essas avaliações destituem $\mathrm{o}$ sujeito de suas potencialidades $\mathrm{e}$ possibilidades, passando a enxergá-lo pelo que supostamente ele não tem ou não pode. Um olhar sobre a diferença que o classifica e o exclui de muitas maneiras, reforçando e reafirmando o que defende e afirma como verdade o diagnóstico médico: ele é diferente.

A diferença, uma vez posta como problema ao longo da história, é, nos dias atuais, um aspecto a ser tratado pela escola e pela Medicina com recursos que possibilitem a adequação desses mesmos diferentes ao processo de ensinoaprendizagem, que os faça acompanhar os demais na evolução dos conhecimentos esperados. A escola das massas já não vê possibilidade de se ajustar a diferenças de ritmos (subjetividades e singularidades) entre indivíduos. Escolhe, portanto, eliminar a diferença.

\subsection{A medicalização e a expropriação do ensino pela supervaloração do diagnóstico}

Com a existência de um processo avaliativo formal e informal dentro da escola, a constatação de que existem sujeitos que não estão acompanhando a proposta pedagógica de forma linear é comum. Mas o que fazer com esses alunos? Essa é uma pergunta que deveria ser respondida dentro do âmbito escolar, mas não é sempre essa a atitude tomada. 
Os processos de ensino-aprendizagem pertencem à esfera da pedagogia, da educação.

Em momento algum desta análise estamos fazendo uma apologia inversa ao trabalho da Medicina. Muito pelo contrário. Reconhecidamente, o surgimento da Medicina ajudou o Homem no trajeto de sua história a continuar seu desenvolvimento. Porém, o que está em questão aqui é a forma como a Medicina, principalmente a psiquiatria, e também outras áreas da saúde (a neurologia, a psicologia, a terapia ocupacional, a pediatria) obtiveram da escola a anuência para se apropriarem da educação e da forma de tratar e cuidar os sujeitos que fazem parte dela.

De fato, a apropriação em questão não aconteceu forçadamente. Esse acontecimento foi na realidade aprovado e desejado pela escola. É uma divisão, no melhor dos sentidos, de responsabilidade pela decisão a ser tomada em relação à vida do outro. O sujeito considerado diferente por não aprender como os demais gera uma infinidade de demandas para a escola; esta, por sua vez, não sabe (mas deveria) como proceder na adequação desse sujeito ao meio e à proposta em questão. Recorre, então, aos meios oferecidos pela ciência médica para resolução de tais problemas, cujo principal instrumento é o diagnóstico:

O diagnóstico, como diz Illich (1975) cria uma penosa desarmonia entre a pessoa diagnosticada e o seu ambiente social, que tende a se organizar contra ela. Isso está assegurado. Ela é destacada pelo que é considerado nela impeditivo de seguir o fluxo comum da vida. Ela instaura as condições de possibilidade para o preconceito, que bane a pessoa para o exílio das condições comuns da vida social. O rótulo é palavra-ato, já preconceito, o obstáculo inaugural ao ato verdadeiramente inclusivo. $O$ conceito de deficiência serve, pois, à exclusão. Eis aí o preconceito da deficiência. É, portanto, um contrassenso falar da inclusão de excluídos quando basta, apenas, não excluí-los, chamando-os apenas pelo próprio nome (TUNES, 2010, p. 54).

Dessa forma, a psiquiatria apresenta para o mundo, através dos DSMs, uma listagem de supostos transtornos que são produzidos, na realidade, por demandas sociais:

O diagnóstico que rotula as deficiências aproxima-se da ficção, uma vez que a distinção conceitual entre normal e patológico, genialidade e retardo ainda não é clara, de modo que os testes de inteligência e as avaliações neurológicas confundem causas e consequências, adquirindo quase um caráter tautológico, na medida em que só reafirmam as dificuldades percebidas pela escola e pela família. As crianças em idade escolar, 
provenientes de classes populares, geralmente são as mais "classificadas" Poe esse modelo, sendo os resultados meramente utilizados como justificativa para o fracasso escolar (TUNES, 2010, p. 26, grifo nosso).

Essas demandas sociais surgem pela dificuldade humana de lidar com aquilo que está fora da esfera do que foi culturalmente instituído como padrão. A escola é o ambiente perfeito para que esses comportamentos tidos como diferentes sejam avaliados, classificados e inseridos em um contexto de anormalidade, pois é na escola que encontramos um grupo médio de pessoas (professores, diretores, coordenadores, orientadores, funcionários de serviços gerais e burocráticos) avaliando formal e informalmente, diariamente, um microcosmo social muito diverso. Dessas avaliações surgem perspectivas, conclusões, posturas e comportamentos que incluem ou excluem os mais diferentes sujeitos:

Quanto mais tempo o aluno passa na escola em contato com professores e outros educadores mais ele é alvo de observações, comentários e até mesmo por meio de gestos e olhares, que podem ser encorajadores ou desencorajadores. Tudo isso compõe a avaliação informal, que se articula com a formal (VILLAS BOAS, 2013, p. 44).

O que se espera de um ambiente escolar, do ponto de vista da família e da sociedade em geral, é que ele seja um espaço de ensino-aprendizagem. O que se espera da escola enquanto instituição de ensino é que seu trabalho pedagógico possa ser refletido na aprendizagem dos seus alunos.

Antes de qualquer coisa, queremos deixar claro que a Medicina enquanto ciência não é a vilã da história. Como já dissemos, a medicalização é uma perversão também dos princípios da Medicina. Sabe-se também que muitas patologias e doenças precisam de medicação e cuidados para que o ser humano possa viver com saúde e conforto.

O que discutimos aqui ao longo deste trabalho é a submissão social, principalmente a relacionada ao ambiente escolar, que existe no tocante à medicalização do sujeito:

Com o consentimento da sociedade, que delega à medicina a tarefa de normatizar, legislar e vigiar a vida, estão colocadas as condições históricas para a medicalização da sociedade; para nosso objeto, mais especificamente, a medicalização do comportamento e da aprendizagem (MOYSÉS, 2001, p. 171). 
A escola, principalmente ela, deveria ser a protagonista dos processos de ensino-aprendizagem levando em consideração as diversidades de comportamentos, personalidades, etnias, históricos sociais, limitações e necessidades que os sujeitos carregam.

Mas parece impossível ou trabalhoso à escola fazer diferenciações básicas como: comportamento diverso e comportamento doente; necessidades especiais e necessidades médicas; transtorno ou suposto transtorno. Existe um caminho mais curto para isso que é a busca pelo socorro, análise e diagnóstico médico. Mas talvez existam outros... 


\title{
Capítulo 3 - CONTRIBUIÇÕES DA FILOSOFIA DA SINGULARIDADE POR UMA ESCOLA NÃO EXCLUDENTE
}

\subsection{Singularidade e semelhança}

Em seu livro seminal, Deleuze afirma, logo na introdução:

\begin{abstract}
A repetição não é a generalidade. A repetição deve ser distinguida da generalidade de várias maneiras. Toda fórmula que implique sua confusão é deplorável, como quando dizemos que duas coisas se assemelham como duas gotas d'água ou quando identificamos "só há ciência do geral" e "só há ciência do que se repete". Entre a repetição e a semelhança, mesmo extrema, a diferença é de natureza, [pois] [...] a generalidade exprime um ponto de vista segundo o qual um termo pode ser trocado por outro [...] [enquanto que] a repetição só é uma conduta necessária e fundada apenas em relação ao que não pode ser substituído. [A repetição diz respeito a uma singularidade não permutável, insubstituível (DELEUZE, 2006, p. 19-20).
\end{abstract}

Assim, com relação ao conceito:

Toda limitação lógica da compreensão do conceito dota-o de uma extensão superior a 1, de direito, infinita; dota-o, pois, de uma generalidade tal que nenhum indivíduo existente pode corresponder-lhe hic et nunc (regra da relação inversa da compreensão e da extensão) (DELEUZE, 2006, p. 34, grifo nosso).

Desse modo, talvez seja adequado retornar ao primeiro capítulo sob a ótica de uma oposição entre a singularidade (objeto precípuo da repetição) e a semelhança; oposição mediada pelo conceito, que ali procuramos desenvolver, de "dificuldade de aprendizagem e desenvolvimento".

Vimos naquele capítulo que a compreensão adequada desse conceito e, portanto, de sua generalidade, decorre precisamente da análise de sua repetição, sempre como essencialmente singular em cada momento histórico.

Assim, a generalidade haurida no conceito só prevalece por termos decidido, desde sempre, "depurar" a repetição de suas singularidades inerentes (inerentemente histórico-sociais, por exemplo).

O conceito é essa depuração, o abandono das diferenças concretas em nome de algum tipo de permanência abstrata (e, portanto, não concretizável em qualquer objeto particular). O que vimos é que não há uma dificuldade de aprendizagem e 
desenvolvimento concreta, mas várias instâncias singulares concretas dessa noção que, só abstratamente, se hipostasia em um conceito.

Assim, nessa nossa própria atitude conceitualizante, por oposição, reside a possibilidade de ampliar os horizontes de nossa compreensão no que concerne ao tema específico que aqui nos interessa, que é a recuperação da diferença como fundamento da existência - uma questão ontológica, portanto -, e retirar daí uma escola inclusiva - uma questão ético política, portanto.

Ampliar essa nossa compreensão para além dos horizontes hermenêuticos (conceituais), essa é a grande dificuldade, uma vez que somos uma sociedade do conceito.

\subsection{A estatística como forma de submeter a singularidade à generalidade}

De modo a superar essa dificuldade, voltemos à questão do uso da estatística, que falamos apenas superficialmente no capítulo dois. Trata-se, pois, de se fazer uma análise filosófica de um procedimento amplamente adotado nas sociedades modernas como forma de constituir conceitos. Um tipo de análise muito usado no método fenomenológico, em que um fenômeno específico (o uso da estatística) é analisado sob a ótica de novas percepções filosóficas.

Do ponto de vista moderno ou contemporâneo, a estatística é o instrumento mais eficaz para se converter a repetição em generalidade. Esse é o seu âmago estrutural como argumentaremos a seguir.

\subsubsection{Média aritmética e outros descritores estatísticos}

De fato, a estatística age sobre objetos reconhecidos de antemão como diferentes (sua condição de possibilidade). Para existir uma estatística, deve-se eleger uma característica ou fator que irá permitir a subsunção dessas singularidades recalcitrantes a uma identidade que a estatística qualifica e quantifica a partir de um descritor particular, como a média aritmética (entre outros tipos de média, como a harmônica ou a geométrica, ou mesmo a ponderada - diferenças que não alteram a análise a seguir). 
Por exemplo, o aluno médio, ou o aluno que, em média, aprende - mas, também, uma média de velocidade em uma estrada e tantas outras formas de se agrupar eventos singulares.

A média aritmética (de uma sequência de números) é matematicamente definida como a soma de todos os números que resultam de uma sequência de observações de uma propriedade, dividida pelo número de observações ${ }^{20}$. Pode ser definida como aquele número que pode substituir todos os outros sem que seu valor final seja modificado ${ }^{21}$.

O estatístico sabe que esse representante médio não existe; que ele é uma mera abstração que se faz das diferenças específicas, justamente pela completa desconsideração por tais diferenças. Pouco importa se em uma estrada há carros que trafegam ou com velocidades sempre abaixo de $60 \mathrm{~km} / \mathrm{h}$ ou sempre acima de $100 \mathrm{~km} / \mathrm{h}$, a média de velocidade pode muito bem recair em $80 \mathrm{~km} / \mathrm{h}$, mesmo que nenhum carro a apresente sequer uma vez. E, de fato, carros concretos viajam a velocidades que variam ao longo do tempo, de modo que, qualquer média aritmética não poderá representar um objeto (carro) particular. Dito de forma menos técnica, no cálculo da média, os excessos compensam as faltas e a média é o representante matemático dessa compensação.

Outros descritores estatísticos com características similares à média são: a moda, considerada como o valor que mais se repete em uma amostra, ou a mediana, que é o valor que separa o conjunto de diferentes resultados em apenas dois subconjuntos de mesmo tamanho.

O estatístico sabe, portanto, que a média aritmética, a moda ou a mediana são descritores por demais pobres. Tanto é que raramente se limita ao uso desse único descritor.

\footnotetext{
${ }^{20}$ Assim, $x=\left(x_{1}+x_{2}+\cdots+x_{n}\right) / n$, sendo $n$ o número de observações e $x_{k}$ o valor numérico obtido para a propriedade $x$ na observação $k$.

${ }^{21}$ Devido à definição matemática da média, se substituirmos todos os $x_{k}$ por $\bar{x}$, teremos, igualmente, $\bar{x}=(\bar{x}+\bar{x}+\bar{x}+\cdots+\bar{x}) / n$.
} 
Figura 2 - Representação esquemática da média, da mediana e da moda para três tipos de distribuição estatística. Em todos os casos, o descritor (média, mediana ou moda) separa a amostra em duas partes. São as chamadas medidas de tendência central.

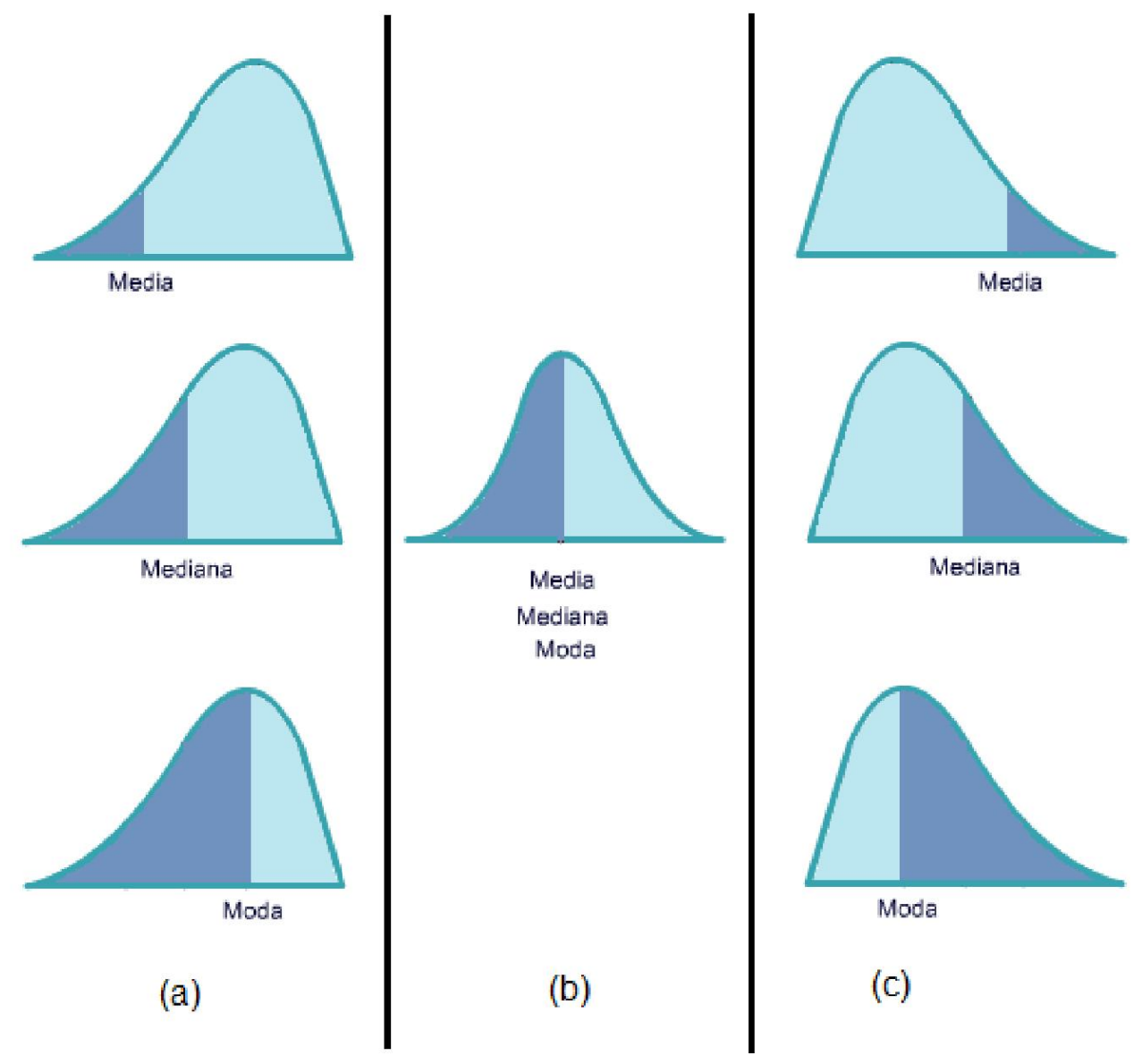

Fonte: A própria autora.

\subsubsection{Variância e curtose}

A partir do descritor referente à média, o estatístico estabelece inúmeros outros descritores, sempre com referência explícita à média, que possam recuperar diferenças inicialmente esquecidas. Assim, o estatístico define a variância como sendo "o desvio quadrático médio da média"22.

\footnotetext{
${ }^{22}$ Matematicamente, a variância $V$ é dada por $V=E\left((x-E(x))^{2}\right)$, onde $E(x)$ é a média, ou seja, a
} variância é definida explicitamente em termo da média. 
Outras medidas (geralmente referidas como medidas de assimetria), como a curtose, são definidas em termos de médias e de desvios quadráticos médios ${ }^{23}-$ ou seja, toda a inomogeneidade da amostra é tomada a posteriori com relação a uma descrição inicial, mais grosseira justamente por desconsiderar tais inomogeneidades, baseada na média.

\section{Figura 3 - A curtose mede o achatamento de uma curva estatística comparada com a curva normal (gaussiana).}

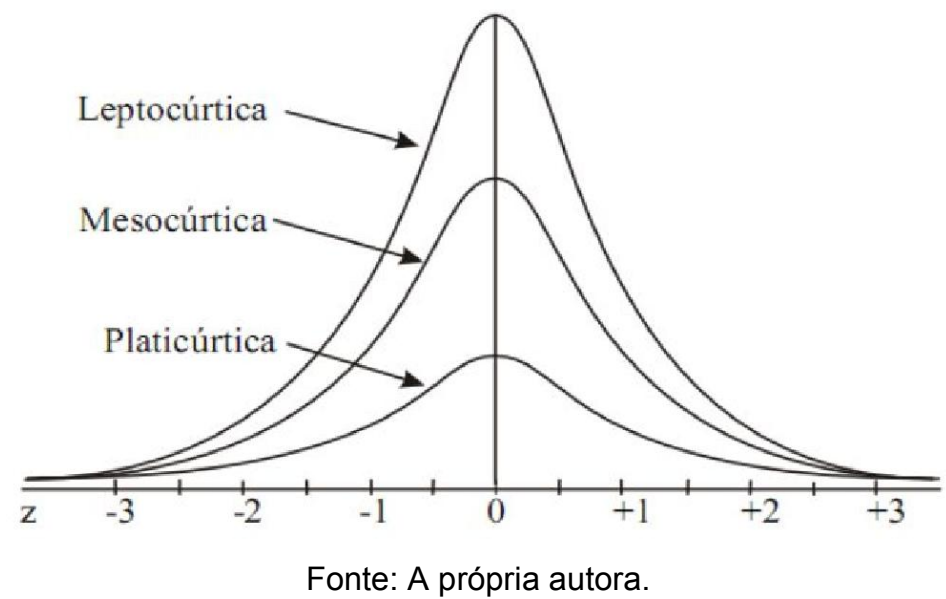

Isso vale para todos os momentos estatísticos de ordem superior, que têm por função caracterizar inomogeneidades (diferenças) cada vez mais sutis em uma amostra inicialmente caracterizada (via média) como essencialmente homogênea (ainda que sabidamente não o sendo - e, de fato, por isso mesmo).

A tensão que surge, entretanto, deve-se ao fato, de resto trivial, que o procedimento de se considerar um momento estatístico de ordem cada vez mais alta só pode recuperar a singularidade por contradição.

De fato, ao considerarmos momentos estatísticos cada vez de ordem mais alta, inserimos em nossa análise cada vez mais divergências de dados com relação à média, ou seja, com relação a uma pretensa homogeneidade da amostra. No limite em que consideramos todos os momentos estatísticos possíveis (infinitos), acabamos por dividir a amostra em praticamente um indivíduo por intervalo - mas aí não faz mais sentido se proceder a uma análise estatística. De fato, a consideração

\footnotetext{
${ }^{23} \mathrm{~A}$ curtose $C$ é definida como $C=E\left((x-E(x))^{4}\right) /\left[E\left((x-E(x))^{2}\right)\right]^{4}$, em que $E(x)$ é a média.
} 
dos infinitos momentos estatísticos é a própria consideração da singularidade do objeto, opaca à estatística.

Há ainda um elemento importante, ao qual voltaremos mais adiante: quanto mais propriedades são analisadas em conjunto (e.g. capacidade de aprendizagem e atenção e assiduidade), mais a amostra tende a tornar a estatística, no limite, obsoleta. Assim, além dos elementos apontados, tem-se ainda que o estatístico deve ser competente o suficiente para isolar características distintas para analisálas separadamente em termos dos descritores estatísticos.

\subsubsection{Probabilidade}

Entendida como medida da frequência estatística de um evento ${ }^{24}$, o conceito de probabilidade está amplamente fundamentado na noção de que elementos da cadeia de repetição são intersubstituíveis, ou seja, fundamentado precisamente na passagem da singularidade de cada um dos acontecimentos a uma generalidade. Essa é, precisamente, a noção de evento estatístico, crucial para a estatística.

Tome-se, a título de exemplo, o caso do lance de um dado. Diz-se que um dado, em um lance qualquer tem probabilidade igual a 1/6 de cair com uma de suas faces para cima. Qualquer lançamento do dado é um evento estatístico absolutamente semelhante, mesmo que tenha ocorrido em situações absolutamente singulares (e.g. diferentes velocidades, diferentes movimentos da mão, rotação, situação do vento no local, altura, ou mesmo diferentes dados sendo lançados) e, inclusive, não reprodutíveis estritamente. O que a probabilidade "limpa" são, de fato, essas singularidades. A probabilidade, ademais, decorre de uma abstração que supõe o(s) dado(s) sendo lançado(s) infinitas vezes.

Assim, a probabilidade, como conceito, surge como forma de nos equilibrarmos, como seres humanos, a partir de nossa finitude, entre dois infinitos inalcançáveis: o conhecimento infinito das condições de lançamento, que nos permitiria saber, com certeza absoluta, qual face iria resultar do lançamento (o conhecimento de uma singularidade qua singularidade); e a ação infinita, pela qual o

\footnotetext{
24 Nem toda a noção de probabilidade se assenta na ideia de frequência estatística. A noção
} bayesiana de probabilidade rejeita essa ideia. 
dado é lançado infinitas vezes, para que, nessa contagem, se possa realmente afirmar a dita probabilidade como sendo igual a 1/6.

No primeiro infinito, encontra-se a singularidade de uma situação única; no outro, a generalidade haurida de situações distintas (mas consideradas como o mesmo evento estatístico - o lançamento do dado) repetidas infinitamente.

E se um dado apresenta probabilidades distintas de 1/6 para o resultado de suas faces frente ao seu lançamento, então esse dado será caracterizado precisamente a partir do dado ideal - e, em geral, o dado será chamado de "viciado".

A metafísica de fundo, portanto, é que as singularidades de cada situação particular, quando suficientemente repetidas, tornam-se irrelevantes para o resultado final, de caráter estatístico, e são hipostasiadas em um descritor como uma probabilidade.

Para que isso possa ocorrer, a estatística necessita de um elemento que the seja exterior, que forneça o critério pelo qual as singularidades possam ser desconsideradas - a estatística não pode dar a si mesma tal critério.

Pelo que já dissemos no capítulo 1, é a organização social que fornece esse critério (e.g. a memória, a iluminação ou o ritmo). Faz surgir, portanto, do memoriado médio, o desmemoriado, do medianamente bem aventurado, o desgraçado, e daquele que se adapta aos ritmos postulados como normais, o lento.

O que esta análise sugere, portanto, é que não há como contemplar a singularidade, de fato, tendo por ponto de partida a análise estatística - a não ser como idealidade, jamais como concretude. O ponto de partida essencial da estatística é sempre a homogeneidade, sendo as diferenciações sempre remetidas a essa homogeneidade (abstrata) fundamental.

Se considerarmos a diferença como uma mitigação da singularidade (que seria diferença em grau infinito), então mantemos o conceito fundado em uma noção de conjunto de elementos e, assim, fundamentado na noção de generalidade, ainda que eventualmente em grau diminuído. Em outras palavras, a noção de diferença permite ainda uma classificação por grupos, em que cada grupo possui um número razoável de indivíduos. Como já mencionamos em capítulo anterior, muitas escolas privadas usam a classificação "aluno normal" e "aluno com laudo" para estabelecer procedimentos como a prova diferenciada. 
Assim, a diferença pode ser representada estatisticamente, a singularidade não - ou então representada de modo trivial e não operacionalizável.

\subsection{A relação da estatística com a medicalização}

Aqui podemos restabelecer a relação íntima entre os métodos da estatística e a ideologia da medicalização. No capítulo anterior, vimos como as diversas síndromes são definidas a partir de noções como "frequentemente", "muitas vezes", entre outras. Tais noções estão fortemente fundamentadas naquelas que a estatística formaliza, mesmo que a psiquiatria as use, quase sempre, de maneira não quantitativa ("muitas vezes", "frequentemente"): o TDAH "muitas vezes" se distrai, o TOD "frequentemente" desafia, e assim por diante.

Essas são maneiras que "mimetizam" o procedimento estatístico que analisamos anteriormente. A partir do critério externo de "número médio de distrações" ou "número razoável de desafios" (geralmente não explicitados), constitui-se o sintoma como desvio desses "valores".

Assim, a definição de muitos supostos transtornos acaba sendo formalmente similar ao estabelecimento de afastamentos de curvas gaussianas (distribuições normais), ainda que muito mais tosca do ponto de vista formal, à medida que pretende estabelecer categorias internamente homogêneas (pelo conceito) relativamente a uma característica externamente estabelecida (a atenção, o desafio, entre outras).

Mesmo que a ideologia medicalizante que se sustenta dessa abordagem possa acessar a diferença, há três problemas estruturais com relação a ela que estão relacionados ao que falamos sobre a própria estatística como método formal: (i) parte-se sempre de uma média, de modo que a singularidade não pode ser jamais alcançada; (ii) parte-se de um único critério (atenção, desafio, etc), ou um conjunto reduzido destes, de modo que todas as outras dimensões são desprezadas (sabe-se bem o problema que introduzem as chamadas comorbidades na identificação e distinção dos supostos transtornos entre si); (iii) por partir-se sempre de uma média, os afastamentos estão sempre referidos a ela.

Em uma perspectiva como essa, a inclusão termina por se manifestar como uma espécie de concessão ou favor: 
Uma primeira estratégia pedagógica, que poderíamos classificar como "liberal", consistiria em estimular e cultivar os bons sentimentos e a boa vontade para com a chamada "diversidade" cultural. Neste caso, o pressuposto básico é o de que a "natureza" humana tem uma variedade de formas legítimas de se expressar culturalmente e todas devem ser respeitadas ou toleradas - no exercício de uma tolerância que pode variar desde um sentimento paternalista e superior até uma atitude de sofisticação cosmopolita de convivência para a qual nada que é humano lhe é "estranho". Pedagogicamente, as crianças e os jovens nas escolas seriam estimulados a entrar em contato, sob as mais variadas formas, com as mais diversas expressões culturais dos diferentes grupos culturais. Para essa perspectiva, a diversidade cultural é boa e expressa, sob a superfície, nossa natureza humana comum. O problema central, aqui, é que essa abordagem simplesmente deixa de questionar as relações de poder e os processos de diferenciação que, antes de tudo, produzem a identidade e a diferença. Em geral, o resultado é a produção de novas dicotomias, como a do dominante tolerante e do dominado tolerado ou a da identidade hegemônica, mas benevolente e da identidade subalterna, mas "respeitada" (SILVA, 2012, p.8)

Nesse sentido, para que nos aproximemos de uma situação, em geral, verdadeiramente includente, é preciso um fundamento mais forte do que a mera diferença. É preciso que se considere, verdadeiramente, a perspectiva da singularidade.

A singularidade, como diferença em absoluto, refere-se, pois a:

[Não] "deixar que o outro seja como eu sou" ou "deixar que o outro seja diferente de mim tal como eu sou diferente (do outro)", mas deixar que o outro seja como eu não sou. Deixar que ele seja esse outro que não pode ser eu, que eu não posso ser, que não pode ser um (outro) eu; significa deixar que o outro seja diferente, deixar ser uma diferença que não seja, em absoluto, diferença entre duas identidades, mas diferença da identidade, deixar ser uma outridade que não é outra "relativamente a mim" ou "relativamente ao mesmo", mas que é absolutamente diferente, sem relação alguma com a identidade ou com a mesmidade (PRADO, 1996, p. 154, apud SILVA, 2012,p.9).

A mera diferença, como singularidade mitigada, não nos parece um conceito suficiente para fundamentar uma ideia plena de inclusão.

\subsection{A fenomenologia da estatística e os DSMs}

Essa análise permite um reposicionamento quando à perspectiva de fundo que leva aos sucessivos DSMs. Como instrumento, o DSM é, basicamente, um conjunto de critérios, ali chamados de sintomas, pelos quais se afirma, em cada classificação, uma existência viciada com relação ao critério escolhido (e.g. 
quantidade de atenção, quantidade de desafios) em termos de uma existência mediana, ideal, que, curiosamente, jamais se explicita.

Classifica-se o indivíduo com base em cada uma das categorias representadas pelo nome do distúrbio, transtorno ou doença. Usa-se, portanto, a mesma estratégia do estatístico, de se isolar uma característica específica para tornar a análise estatística possível. Assim, em cada categoria psicológica/psiquiátrica se estabelece um critério de normalidade.

Essa é, de fato, a base do método analítico formalizado por René Descartes (1973), no século XVI, em seu Discurso do Método, obra fundamental para o Renascimento.

Mas o que ocorreria se nos perguntarmos pela existência como um todo, ou seja, a existência humana, como um apanhado de todas $^{25}$ essas categorias psicológicas/psiquiátricas?

De fato, tal existência ideal pareceria ser passível de ser o resultado de todo o DSM por exclusão, ou seja, como aquela existência que precisamente não recai em qualquer um de seus "diagnósticos".

No DSM essa normalidade como um todo, sempre estatística, é sujeito oculto que, supostamente, poderia ser descrita como aquilo que não é autismo, nem TDAH, nem dislexia, nem TOD...

Há, argumentamos, uma razão profunda para isso: como o DSM é um texto em aberto, sujeito à inclusão cada vez maior de diferenciações comportamentais, simplesmente não há como explicitar a normalidade geral, relativa à existência como um todo, nessa versão ou em outra qualquer. Mais do que sujeito oculto, no DSM tal normalidade, vista como a não participação nas classificações apresentadas, é sujeito inexistente. Mais ainda, como prática estatística por excelência, a inclusão de todas as categorias e os graus de afeto (e.g. grau de TOD, grau de TDAH, grau de transtorno do espectro autista) em uma única análise estatística levaria à conclusão óbvia e estatisticamente inútil de que cada indivíduo apresenta elementos dessas categorias em graus que Ihes são particulares e cuja combinação não se repete em outro indivíduo.

O DSM, com suas versões, parece fazer algo similar à estatística, mas vai ainda mais longe: fala das sucessivas diferenciações do mediano em cada

25 A diferença entre cada e todas aqui é crucial para expor a diferença entre uma abordagem analítica e uma abordagem sintética, como argumentaremos. 
categoria psicológica, na ânsia por buscar o singular, sem jamais explicitar de qual existência mediana se fala.

Assim, o máximo que o DSM pode fazer é usar critérios, normatizações ou classificações para estabelecer o que é mediano em cada critério ou classificação. Assim, cria-se a medianidade da qual o autismo se desvia, a medianidade da qual o TDAH se desvia, e assim por diante. Entretanto, repete-se aqui a pergunta: de qual normalidade uma existência sinteticamente considerada se desvia?

A ontologia de fundo que permeia o DSM, acreditamos, é que, assim como na estatística, a soma das medianidades específicas, de cada "diagnóstico", forneça a medianidade da soma, a medianidade da existência.

A psicologia adota uma versão do preceito analítico de que o conhecimento das partes pode sempre levar ao conhecimento do todo. Evidentemente, a questão é saber se os entes concretos, os seres humanos concretamente existentes, acompanham o preceito, ou se há, aí, uma diferença essencial entre o analítico e o sintético.

A ilusão que identificamos nesse procedimento é considerar, contrariamente à estatística, que haverá algum sujeito concreto (e, de fato, muitos) que recairão sob essa medianidade como um todo, constituindo-se em uma classe concreta de sujeitos normais.

Entretanto, quanto mais se busca atingir a especificidade da vida humana, com a criação de mais e mais critérios de diferenciação, ou categorias psicológicas (e.g. transtornos, déficits), menos sujeitos concretos restam na dita classe de normalidade. O próprio desenvolvimento histórico do DSM, em suas sucessivas edições, mostra precisamente que quanto mais categorias se elegem, menos chance há de encontrar um indivíduo que possa ser classificado como "normal" em todas elas. A leitura de qualquer número do DSM por qualquer pessoa intelectualmente honesta irá mostrar que ela irá se considerar enquadrada em diversas classificações ali existentes, em graus variados. E quanto mais se sucedem os DSMs, maior a quantidade de categorias ou classificações em que um indivíduo usual irá recair.

Os sucessivos DSMs, ao final, sustentam, sem o saber, exatamente o que defendemos aqui: a especificidade infinita da existência como síntese das diferenças, sua singularidade. 
Entretanto, o percurso que os DSMs adotam faz isso de uma forma particularmente perversa. Isso se dá justamente por serem capazes de falar apenas de diferença comportamentais específicas, a partir de seu referencial analítico, sem se dar conta de que, consideradas em conjunto, como existência, tais diferenças referem-se a uma classe vazia de sujeitos concretos.

A perversidade vem, portanto, do fato de que, ao considerar cada especificidade "diagnóstica", os DSMs criam reificações (ou naturalizações da diferença) que são opostas à conclusão que se pode haurir de suas sucessivas edições: de que a soma das diferenças é, afinal, singularidade e, portanto, inclassificável.

A conclusão a que se deveria chegar, já no atual DSM-V e mesmo em seus anteriores, é que a tal média das medianidades tanto buscada é uma classe constituída de seres concretos que atendem, em variados graus e de formas diversas, a inúmeros critérios ou sintomas ali apresentados e que, portanto, a classe da normalidade concreta, sintética, diferentemente da abstrata, analítica, não é obtida pelo critério de exclusão (por não apresentar cada um dos conceitos), mas pelo critério da inclusão variegada em tais critérios (por apresentá-los sempre e em cada vez, de forma singular).

A escola, especificamente, ao tratar de sujeitos concretos, deveria ater-se, portanto, à referida classe da normalidade concreta, constituída sinteticamente a partir da singularidade da existência, e não como o faz hoje em dia, quando se volta para a classe abstrata e vazia de uma normalidade analítica, matemática e sem concretude, impossível.

\subsection{A singularidade como ontologia de fundo para o problema da educação}

Como dissemos, no capítulo 1, muitas vezes temos uma ontologia de fundo (e.g. o conhecimento como memória e a existência de uma natureza humana fixada ao se nascer - Platão) determinando, a partir de critérios sociais (e.g. o critério de justiça - Platão), um tipo específico de comportamento (ética) ou de procedimentos sociais (política).

Em todos os exemplos históricos que apresentamos no capítulo 1, está sempre posto o pressuposto fundamental da prioridade da semelhança sobre a singularidade. As variações históricas que se sucederam não foram capazes de 
evitar o problema da exclusão, mas apenas deslocá-lo à medida que o critério de análise (memória, iluminação ou eficiência) ia se alterando. Essa permanência da exclusão, mesmo com as diferenças óbvias das instanciações históricas particulares, sugere que o fundamento da exclusão está em um plano de considerações metafísicas ainda mais abstrato do que o epistêmico de Platão, o religioso de Santo Agostinho ou o pragmático da sociedade burguesa.

Consideramos que esse axioma metafísico básico é expresso exatamente pela ideia de que a singularidade é ontologicamente secundária com relação à semelhança e pode, portanto, ser avaliada ou mensurada com relação a esta.

Uma vez que se parta de tal metafísica ou ontologia de fundo, já está validada a ideia de que se podem tratar as existências humanas concretas como se tratam os lançamentos de um dado - como eventos intersubstituíveis.

Vistos como eventos intersubstituíveis no interior de uma abordagem analítica, as existências humanas concretas podem ser classificadas (em quartis, decis, centis que podem assumir, como ocorre atualmente, a roupagem de categorias psiquiátricas). Assume-se, portanto, que há homogeneidades nessas existências humanas concretas, mesmo que mitigadas pelas subclassificações que instauram a diferença - sempre a partir de um referencial que as hierarquiza.

As existências concretas se tornam, assim, conceituáveis e hierarquizáveis e, a partir daí, a diferença só pode existir referida à tolerância, não como autenticidade (estritamente: a auto - enticidade, o ser que se constitui a partir de si mesmo).

\footnotetext{
Dividir o mundo social entre "nós" e "eles" significa classificar. O processo de classificação é central na vida social. Ele pode ser entendido como um ato de significação pelo qual dividimos e ordenamos o mundo social em grupos, em classes. A identidade e a diferença estão estreitamente relacionadas às formas pelas quais a sociedade produz e utiliza classificações. As classificações são sempre feitas a partir do ponto de vista da identidade. Isto é, as classes nas quais o mundo social é dividido não são simples agrupamentos simétricos. Dividir e classificar significa, neste caso, também hierarquizar. Deter o privilégio de classificar significa também deter o privilégio de atribuir diferentes valores aos grupos assim classificados (SILVA, 2012, p.3).
}

A inversão do processo se dá se partimos justamente de uma ontologia oposta: a ontologia da singularidade, em que se afirma, de antemão, o caráter absolutamente singular de cada existência humana sinteticamente considerada e, portanto, das singularidades que permeiam as relações que essas existências 
guardam com instâncias homogeinizadoras como são as instituições (dentre elas, a escola).

Esse ponto de partida bloqueia, precisamente, a possibilidade de se submeter as existências concretas a conceitos e classificações (psiquiátricos, psicológicos, estatísticos em geral, religiosos, etc.)

Não significa bloquear a estatística, por exemplo, como método de análise de exames escolares - significa simplesmente bloquear o passo seguinte, de referir essas análises a categorias de indivíduos (e, daí, a doenças, síndromes ou transtornos). Ou, ainda, bloqueia um passo ulterior, mais abjeto, de construir exames escolares mais simplificados para "recolocar" existências humanas concretas no interior da categoria assumida como normal ou mediana. Ou de se entupir uma criança ou adolescente de remédios para que se ajustem ao comportamento assumido como normal ou médio.

Trata-se de assumir que, se no lançamento do dado singularidades são eventualmente irrelevantes, pois se procura estabelecer seu comportamento relativo apenas à característica de cair com essa ou aquela face voltada para cima, no caso de existências humanas concretas (em particular na escola) são as singularidades que devem ser atendidas. E isso justamente porque ali, na escola, as existências devem ser consideradas em sua totalidade sintética, não como fatores analíticos que, ao serem reunidos a posteriori, recuperam tais existências em sua concretude. Essa visão sintética ensejaria, pois, a verdadeira pedagogia da pessoa completa.

Sustentamos que somente tal inversão de perspectiva pode fazer com que a escola assuma sua responsabilidade na relação que se estabelece no ensino, entre ela e cada aluno.

E o que fazer com um aluno "portador" de alguma "deficiência"? Poder-se-ia perguntar. Há que se notar que nem a noção de portador, nem a noção de deficiência podem ser articuladas no contexto de uma ontologia de fundo calcada na singularidade.

A pergunta, entretanto, pode ser refeita nos seguintes moldes: e o aluno que sofre na escola (em particular)? Essa pergunta é perfeitamente articulável no contexto de uma filosofia da singularidade, uma vez que o sofrimento carrega consigo, exatamente, essa marca da especificidade - e talvez a carregue de maneira eminente. 


\title{
3.60 mal estar na escola
}

A pergunta feita no final da seção anterior permite exemplificar, exatamente, o tipo de mudança de perspectiva (e de ética e de política) que pode ensejar a inversão ontológica proposta.

Aqui podemos lançar mão da distinção, feita em algumas abordagens em Filosofia, entre "doença" e "mal-estar" (MARINOFF, 2003). A diferença coloca em contraste exatamente a noção de um conceito classificador (doença = categoria dos sujeitos que recaem sob um conjunto de sintomas que caracterizam a doença) para um meramente identificador (mal-estar, eminentemente singular, pois derivado do ser-no-mundo da pessoa como um ser total, sintético).

De fato, o conceito fundamental que perpassa a questão da distinção entre doença e mal-estar é aquele, como esperado, de normalidade.

\begin{abstract}
A arte e a ciência médica dedicam-se a manter a saúde, sarar as feridas e curar as doenças. O que é doença? Em geral, é uma coisa que afeta o corpo de forma a atrapalhar ou impedir seu funcionamento normal. [...]

Ainda assim, devemos considerar que a definição de 'funcionamento normal' baseia-se, em parte, em normas sociais, além de biológicas. [...] [Assim] mesmo as 'doenças', democraticamente eleitas ${ }^{26}$, do chamado tipo mental podem ser consideradas normais, caso as circunstâncias sociais sejam propícias. Mas esta [...] é uma rua de mão dupla. Se as circunstâncias sociais forem propícias, muitos problemas que de jeito nenhum são doenças podem ser 'diagnosticados' como se fossem. [...] Também é claro que se pode abusar da prática médica como meio de controle social ou político (MARINOFF, 2003, p. 19 et seq.)
\end{abstract}

A questão contra a qual gostaríamos de nos colocar aqui é justamente aquela da sindromização do comportamento, ou seja, a transformação em síndrome, transtorno ou distúrbio de tudo aquilo que implica ou deriva de singularidade existencial. Comportamentos que colocam em cheque as regras socialmente estabelecidas de funcionamento "normal" de uma sociedade ou grupo (como, por exemplo, o grupo escolar e seus ritmos).

A diferença entre doença e mal-estar se dá por que:

26 “O TEPT (Transtorno do Estresse Pós-Traumático) é uma doença real? Ou é meramente um malestar? É classificado como 'doença' pelo DSM (Manual de Diagnóstico e Estatística) da Associação Psiquiátrica Americana. Assim que algum mal-estar é votado para ser incluído no DSM como 'doença', os psiquiatras e psicólogos clínicos podem 'diagnosticá-lo'. Sim, as 'doenças' do DSM são democraticamente eleitas! Cada vez mais o gerenciamento dos custos da assistência médica exige que os terapeutas da palavra façam 'diagnósticos' [...] (MARINOFF. Pergunte a Platão, 2003, p. 21). 
Em todos os estágios da vida, fazemos perguntas importantes sobre nós e os outros, nossos problemas e os de todo mundo, o mundo inteiro e o universo ainda maior, o significado e o objetivo de nossa existência. Investigamos todos os assuntos concebíveis. Os seres humanos querem e precisam entender o sentido do que acontece - ou não - em curto prazo e em prazo ainda mais longo. Nossa capacidade de indagar é nosso meio principal para isso. Todo mundo faz ainda mais perguntas em épocas de dificuldades e tribulações; quanto mais difícil a situação, mais abrangentes as questões. Mas, ironicamente, às vezes as respostas que buscamos com mais urgência são as mais difíceis de encontrar.

[...] Todo mundo tem um passado e quase todo mundo lamenta ter feito ou não certas coisas, e quase todo mundo consegue recordar coisas agradáveis e desagradáveis que lhe aconteceram. Como orientador filosófico, eu diria que quem se sente incomodado com o passado tem algum mal-estar, mas não necessariamente uma doença. Tratar a doença como se fosse um mal-estar é um tipo de erro; tratar o mal-estar como se fosse doença é outro (MARINOFF, 2003, p. 17)

A dificuldade, entretanto, está em estabelecer as diferenças, pois:

assim como você deveria ser considerado inocente até que provassem sua culpa em questões criminais, também deveria ser considerado estável, funcional e saudável até que provassem sua instabilidade, disfunção ou insanidade em questões civis, ou seja, na conduta pessoal e profissional da sua vida. Mas as suposições de inocência e a de sanidade foram desgastadíssimas nos últimos anos por forças políticas, sociais e comerciais que trabalharam arduamente para minar suas liberdades fundamentais. Isso torna mais difícil conseguir imparcialidade no tribunal, assim como uma opinião isenta de profissionais de 'saúde mental' sobre seu mal-estar (MARINOFF, 2003, p. 22)

Ficamos, pois, com a diferença básica entre doença e mal-estar. Uma diferença que, como iremos argumentar, estabelece uma nova perspectiva sobre o problema da medicalização.

Mas, dada a existência dessas duas esferas distintas de manifestação, doença e mal-estar, que relação poderia existir entre elas, se é que há alguma relação afinal?

A verdade é que:

Um mal-estar, quando não se transforma em bem-estar, pode acabar se transformando em doença. [...] Um estado persistente de mal-estar pode influenciar ou estragar os pensamentos, as palavras e os atos e afetar também, negativamente, o bem-estar emocional e físico. Um dilema moral não resolvido, uma injustiça não sanada ou um objetivo não atingido são, todos, fontes de mal-estar; se não forem examinados filosoficamente podem, com toda certeza, manifestar-se como problemas psicológicos e até clínicos mais adiante (MARINOFF, 2003, p. 27) 
De modo que há uma relação de mão dupla entre doença e mal-estar, ainda que se situem em níveis diferentes no plano ontológico (e sua identificação seria justamente a passagem do singular ao geral). Note-se que não se está, portanto, tentando substituir ou suplantar a psiquiatria ou a psicologia (ou a psicopedagogia).

Reconhecemos, pois, os lugares de articulação da psiquiatria, da psicologia e da psicopedagogia - o que desejamos, entretanto, é estabelecer os limites desses lugares, em particular no que concerne a sua articulação na esfera escolar.

Tal pergunta sobre as relações entre mal-estar e doença tem papel fundamental no estabelecimento desses lugares. Parece razoável supor que o malestar tem precedência sobre a doença quanto ao caráter ontológico fundamental que apresenta (de forma análoga à que o singular tem sobre o geral).

De fato, é razoável supor que pode haver mal-estar sem doença subjacente, mas não é provável haver doença (em particular a de caráter "mental", que nos interessa aqui) sem mal-estar. Em particular porque doenças desse tipo são caracterizadas exatamente por um desajuste social frente a regras de um grupo, e o mal-estar praticamente decorre dessa caracterização. Tem-se, na articulação desses conceitos de mal-estar e doença com aquele de existência, uma relação como a apresentada na figura a seguir.

Figura 4- As relações entre mal-estar e doença $x$

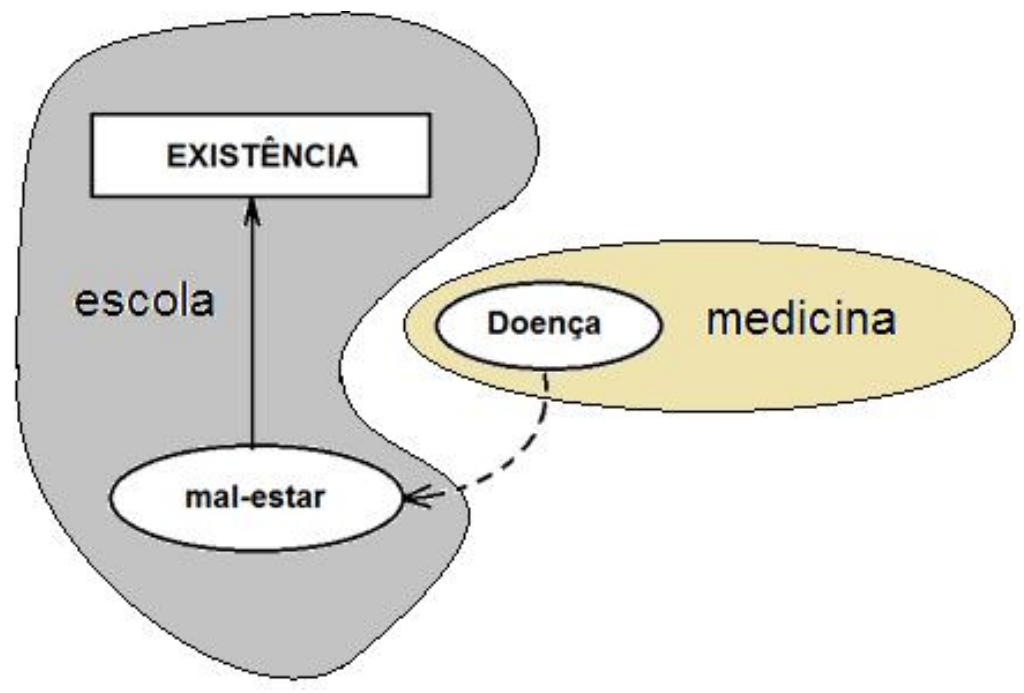

Fonte: A própria autora. 
Essa percepção do problema permite estabelecer esferas distintas de intervenção, e mesmo estabelecer certa independência entre tais esferas. De fato, se há a identificação de algum tipo de doença, cabe a médicos, psicólogos e psiquiatras estabelecer mecanismos de intervenção que possam atuar nessa esfera.

Entretanto, seja qual for a origem do mal-estar, se derivado de uma doença ou apenas do ser-no-mundo do indivíduo, é este mal-estar que deve ser superado no âmbito da ação do professor no meio escolar - pela consideração de sua singularidade. De fato, dado o caráter mais fundamental do mal-estar, nada garante que, retirada a doença, retire-se o mal-estar.

De fato, mesmo na lógica da medicalização, se o aluno tem uma doença e está devidamente medicado (de modo que o mal pode ser considerado superado ou sob controle), não há porque estabelecer estratégias de diferenciação a posteriori entre tais alunos e aqueles "sãos".

Se o problema é o deficit de atenção e o aluno toma medicamento que restabelece seus níveis de atenção, por que se continua a indicar para ele a realização de provas diferenciadas, visivelmente direcionadas para uma menor exigência de seu aparelho cognitivo (mesmo não havendo relação do transtorno com a esfera cognitiva propriamente)? Se isso parece ser necessário, a conclusão a se adotar aqui é que a medicação não alterou minimamente aquilo que, na esfera escolar, deveria ter sido alterado. Chamamos esse elemento de mal-estar.

A diferença torna-se ainda mais trivial quando se percebe que uma doença mental particular não tem como determinar um tipo particular de existência; quem faz isso é a interpretação que o sujeito faz desses elementos, de o que significa ser doente, dos elementos de exclusão social que disso podem derivar (sobre isso, ver capítulo 5).

Esse elemento de interpretação ou representação, que media a doença e a existência, é de caráter conceitual e se articula, precisamente, na esfera do malestar - decorre das especificidades da existência concreta do indivíduo, especificidades que estabelecem sua singularidade e a colocam em relação com o mundo. Não há vínculo direto entre doença e existência, pelo simples fato de diferentes indivíduos diagnosticados como apresentando doenças similares construírem para si, cotidianamente, diferentes formas de ser-no-mundo (ver capítulo 5). 
Em resumo, o estabelecimento da diferenciação entre mal-estar e doença permite resguardar os lugares de atuação dos diversos profissionais interessados no processo de ajuda no âmbito escolar. O professor, atuando na esfera do mal-estar, pode fazê-lo com independência das ações na esfera da doença, ainda que possa (e talvez deva) levá-la em consideração na adoção das estratégias mais eficazes para lidar com seus alunos em geral.

Essas considerações servem como um exemplo concreto de mudança de perspectiva quanto à atuação na escola decorrente de uma mudança nas concepções ontológicas relativas ao humano. 


\section{Capítulo 4 - METODOLOGIA}

\subsection{Contextualizando o método qualitativo}

Utilizamos a pesquisa qualitativa neste trabalho. Escolhemos a pesquisa qualitativa para esta pesquisa, pois

pode ser caracterizada como a tentativa de uma compreensão detalhada dos significados e características situacionais apresentadas pelos entrevistados, em lugar da produção de medidas quantitativas de características ou comportamentos (RICHARDSON apud LAKATOS \& MARCONI, 2011, p. 271).

As informações, ou dados, obtidos ou construídos nesta pesquisa levaram em consideração as vivências apresentadas pelos sujeitos envolvidos na pesquisa. Nesta pesquisa levamos em consideração todas as informações recolhidas que são pertinentes ao tema.

Nesta pesquisa foi necessário que nós levássemos em consideração todos os aspectos que foram apresentados nas falas dos sujeitos. As falas estão geralmente carregadas de crenças, valores, aspirações, desejos, necessidades, impressões, lembranças, entre outros aspectos. Todos esses aspectos tecem uma importante teia que foi analisada, estudada e compreendida pelo pesquisador.

Nossa pesquisa necessitou de um olhar atento e preparado do observador/pesquisador para os detalhes que foram surgindo no decorrer da pesquisa, pois esta não foi uma metodologia que se construiu a partir do dado frio, mas sim a partir da interação entre 0 sujeito da pesquisa e 0 observador/pesquisador.

Esta pesquisa trabalhou com questões particulares que envolveram detalhes que não podem ser mensurados ou quantificados, detalhes esses que estão diluídos nas falas significativas do sujeito.

O uso desta metodologia nos permitiu e exigiu do pesquisador o uso da observação atenta e reflexiva como ferramenta auxiliar ao processo de obtenção dos dados, pois pequenas impressões e percepções ajudaram na interpretação e análise dos dados. Outras ferramentas foram utilizadas para o armazenamento dos dados como recursos de áudio e diários de anotações. 
Os registros serviram como guia e garantia para um bom desenvolvimento da análise dos dados obtidos/construídos. A pesquisa não apresenta rigidez na obtenção dos dados, "o entrevistador tem liberdade de acrescentar outras perguntas no decorrer das respostas" (LAKATOS \& MARCONI, 2011, p. 274).

Nossa pesquisa não se interessou pela simples interpretação dos dados, mas por todo um acompanhamento e uma reflexão contínua das situações observadas.

\subsection{0 método qualitativo e a interação com esta pesquisa}

Este método foi o mais interessante para esta pesquisa por possibilitar a interação entre o pesquisador e os sujeitos da pesquisa. A contribuição desse método para a pesquisa é a oportunidade de ter acesso ao discurso falado dos sujeitos em questão. O dado frio, próprio da pesquisa quantitativa, não teria possibilidade de construção análise dos dados em uma pesquisa, na qual a relevância se encontra nas falas dos sujeitos.

O método escolhido possibilitou ao pesquisador visualizar dados que vão além do presente, encontrando material de análise no passado do sujeito da pesquisa e suas aspirações em relação ao futuro,

a metodologia qualitativa preocupa-se em analisar e interpretar aspectos mais profundos, descrevendo a complexidade do comportamento humano. Fornece análise mais detalhada sobre as investigações, hábitos, atitudes, tendências de comportamento etc. (LAKATOS \& MARCONI, 2011, p. 269).

No caso desta pesquisa, a análise das falas dos sujeitos de forma mais detalhada foi de grande importância para o entendimento do conjunto dos dados fornecidos.

Neste caso, as ferramentas da metodologia escolhida foram usadas para ouvir, analisar e interpretar os dados fornecidos pelos três sujeitos da pesquisa com o objetivo de identificar no âmbito individual situações que podem ser estendida de forma análoga para o geral.

Para podermos ouvir de forma atenta aos sujeitos da pesquisa, escolhemos a entrevista qualitativa como método de acesso aos dados, pois: 
pessoa (o entrevistador) e outra (o entrevistado) ou outras como um pequeno grupo ou uma família. (LAKATOS \& MARCONI, 2011, p. 273).

a entrevista deve ser um diálogo espontâneo, porém profundo, aberto, cuidadoso, descartando perguntas muito diretas. Devese também evitar incomodar o entrevistado com perguntas tendenciosas. (LAKATOS \& MARCONI, 2011, p. 273).

$\mathrm{Na}$ busca por alcançar o máximo das possibilidades apresentadas pelo método da pesquisa qualitativa, descrevemos no primeiro momento a estratégia de seleção e aproximação dos sujeitos da pesquisa, logo em seguida descrevemos as interações dos sujeitos com a metodologia da pesquisa, os resultados dessa interação e na sequência apresentamos as percepções possíveis extraídas pela pesquisadora das experiências descritas por esses sujeitos.

\subsection{Objetivos}

\subsubsection{Objetivo geral}

Compreender a relação entre o suposto diagnóstico de transtorno de aprendizagem e a percepção que esses sujeitos diagnosticados têm a respeito do que podem e como podem aprender na escola.

\subsubsection{Objetivos específicos}

a. Compreender a relação entre a escola-sujeito após a emissão do diagnóstico clínico de suposto transtorno de aprendizagem;

b. compreender as falas significativas a partir dos sujeitos da pesquisa;

c. compreender a auto-imagem do sujeito após a emissão do diagnóstico médico suposto de transtorno de aprendizagem. 


\subsection{Procedimentos para a coleta e análise dos dados/informações}

Para a realização desta pesquisa, aplicando o método qualitativo, utilizamos na ordem estabelecida os procedimentos para a produção e análise de informações:

a) Procedimentos para A PRODUÇão de INFORMAÇÕES:

a.1) apresentação e convite para participação da pesquisa;

a.2) apresentação do Termo de Consentimento Livre e Esclarecido (TCLE) para ser assinado pelo responsável do participante menor de idade;

a.3) entrevistas individuais (com gravação de áudio);

a.4) acesso ao documento que prescreve/credita o diagnóstico clínico de suposto transtorno de aprendizagem ao sujeito da pesquisa.

b) Procedimentos de ANÁlise dos dados Coletados:

b.1) transcrição das gravações de áudio, apreciação sem interpretações iniciais;

b.2) interpretações iniciais das transcrições ouvidas;

b.3) análise do documento que prescreve/credita o diagnóstico médico de transtorno de aprendizagem ao sujeito da pesquisa;

b.4) redação dos aspectos conclusivos da pesquisa.

É necessário deixar claro que tanto durante a produção das informações quanto durante a análise dessas informações, a conexão com o referencial teórico foi constante para que os significados necessários ao entendimento do trabalho não se perdessem.

\subsection{Instrumentos}

Para este trabalho elegemos, de acordo com o objetivo pretendido, a utilização de: entrevista individual aberta, observação, análise documental e análise dos dados. Faremos, a seguir, o detalhamento da utilização de cada instrumento escolhido (ver também o Quadro 1).

- Entrevista individual aberta: utilizamos um roteiro previamente elaborado (para servir de guia) com base na temática escolhida, oportunizando que as "falas significativas" aconteçam em um ambiente individualizado. 
- Observação: uma estratégia necessária para analisar o desenvolvimento das posturas, comportamentos e emocionalidade dos sujeitos participantes da pesquisa.

\begin{tabular}{|l|l|l|}
\hline \multicolumn{2}{|c|}{ Quadro 1 - Sinopse } \\
\hline \multicolumn{1}{|c|}{ INSTRUMENTO } & \multicolumn{1}{|c|}{ OBJETIVO } & \multicolumn{1}{c|}{ PARTICIPANTES } \\
\hline Entrevista aberta & $\begin{array}{l}\text { Ouvir a enunciação das } \\
\text { falas de forma } \\
\text { individualizada. }\end{array}$ & $\begin{array}{l}\text { Sujeito da pesquisa - } \\
\text { individual. }\end{array}$ \\
\hline Observação & $\begin{array}{l}\text { Observar as posturas, } \\
\text { comportamentos e } \\
\text { emocionalidade dos } \\
\text { sujeitos da pesquisa. }\end{array}$ & $\begin{array}{l}\text { Sujeitos da pesquisa - } \\
\text { individual. }\end{array}$ \\
\hline Análise documental & $\begin{array}{l}\text { Analisar os documentos } \\
\text { que afirmam o transtorno } \\
\text { de aprendizagem. }\end{array}$ & $\begin{array}{l}\text { Sem a participação dos } \\
\text { sujeitos da pesquisa. }\end{array}$ \\
\hline Análise das informações & $\begin{array}{l}\text { Analisar o conteúdo das } \\
\text { falas dos sujeitos da } \\
\text { pesquisa }\end{array}$ & $\begin{array}{l}\text { Sem a participação dos } \\
\text { sujeitos da pesquisa. }\end{array}$ \\
\hline
\end{tabular}

Fonte: Das autoras.

- Análise documental: interpretação dos documentos que afirmam e esclarecem o diagnóstico em questão.

- Análise das informações: análise dos dados através do método qualitativo. 


\subsection{Apresentação das informações}

Para a coleta das informações desta pesquisa, dispusemos de um encontro para entrevista com cada um dos participantes. Selecionamos três sujeitos para a pesquisa: duas meninas e um menino. Todos adolescentes entre 13 anos e 16 anos de idade.

Os sujeitos da pesquisa estão matriculados em escolas privadas do Distrito Federal, os três apresentam diagnósticos de supostos transtornos de aprendizagem, um deles apresenta uma reprovação recente justificada pela existência do diagnóstico de suposto transtorno de aprendizagem; dois deles apresentavam domínio sobre o que é o diagnóstico médico e qual a sua função pedagógica; um deles não compreendia muito bem o que é o diagnóstico, mas entendia qual a sua função.

A seleção dos sujeitos da pesquisa foi feita a partir de informações obtidas pela pesquisadora em sua experiência como docente ao longo de alguns anos (2008/2013) em diferentes escolas privadas da cidade de Brasília, Distrito Federal.

As informações foram produzidas a partir da escuta dos enunciados dos sujeitos. As falas dos sujeitos da pesquisa foram produzidas em uma entrevista individual semi-estruturada, com a utilização de aparelho de gravação digital e anotações feitas pela pesquisadora.

\subsection{Análise das informações}

A análise das informações buscou atingir os requisitos que compõem as necessidades e exigências do método da pesquisa qualitativa. Dessa forma, descrevemos no primeiro momento a estratégia de seleção e aproximação dos sujeitos da pesquisa, logo em seguida descrevemos as interações dos sujeitos com a metodologia da pesquisa, os resultados dessa interação e na seqüência apresentamos as percepções possíveis extraídas pela pesquisadora das experiências descritas por esses sujeitos. 


\subsection{Aspectos éticos}

Seguindo as orientações clássicas que permitem a realização de uma pesquisa qualitativa com seres humanos, os seguintes passos e documentos serão utilizados:

- abordagem dos responsáveis pelas pessoas que participam das pesquisas;

- apresentação e assinatura do TCLE, no qual constam os dados da pesquisa, os dados do pesquisador, os objetivos, a agenda de encontros, o compromisso com o sigilo e a proteção dos dados por parte do pesquisador, a não ocorrência de custos e nem de pagamentos para ambas as partes e o esclarecimento da possibilidade de o sujeito da pesquisa poder abandoná-la a qualquer momento sem nenhum prejuízo para ele;

- após a conclusão do trabalho de pesquisa, os sujeitos da pesquisa serão convidados para um feedback dos resultados alcançados, e o pesquisador ficará à disposição para discutir as conclusões a que chegou de acordo com o interesse de cada participante.

Outro aspecto ético importante da pesquisa é sua relevância para o meio social a que está sendo proposto. Dada a importância do estudo da aprendizagem, do desenvolvimento dos estudantes, a vasta discussão existente sobre a problemática da medicalização, da análise da diferença e da singularidade, da multiplicação dos diagnósticos de supostos transtornos de aprendizagem nos últimos anos e da importância da relação professor-aluno, encontramos em nossa discussão elementos importantes para sua existência e efetivação..

\subsection{Sujeitos da pesquisa}

Os sujeitos da pesquisa são jovens matriculados em escolas tradicionais, privadas, de ensino regular da cidade de Brasília - Distrito Federal que foram diagnosticados com supostos transtornos de aprendizagem. Os sujeitos da pesquisa têm idades entre: 113 anos e 16 anos, e possuem autorização dos responsáveis para serem entrevistados..

Dos e-mails enviados, oito no total, todos foram respondidos com diferentes respostas a respeito da participação na pesquisa. Três convidados a serem sujeitos da pesquisa foram selecionados para a execução do trabalho, dois do sexo feminino 
e um do sexo masculino. Todos adolescentes entre 13 anos e dezesseis 16 anos de idade.

Nas escolas onde estão devidamente matriculados, os sujeitos da pesquisa frequentam as aulas em salas regulares de ensino, mas possuem o atendimento especial direcionado a cada um de acordo com as orientações prescritas no diagnóstico individual, incluindo a já citada e explicada, em capítulo anterior, prova diferenciada.

Os dados gerais, que podem, de acordo com o tratamento ético dado a pesquisa: sigilo, cuidado e proteção, ser dispostos e que contextualizam melhor os sujeitos da pesquisa serão disponibilizados nas fichas das entrevistas individuais semi-estruturadas.

A seleção dos sujeitos da pesquisa foi feita a partir de informações obtidas pela pesquisadora, em sua experiência como docente ao longo de alguns anos (2008/2013), em diferentes escolas privadas da cidade de Brasília no Distrito Federal.

O convite para participação nesta pesquisa foi feito à família/responsável de estudantes que foram matriculados nas escolas privadas, nas quais a docente trabalhou, e que apresentaram à coordenação pedagógica diagnósticos/laudos de algum suposto transtorno de aprendizagem.

Essa mesma documentação diagnóstica é compartilhada pela coordenação pedagógica com a equipe docente na intenção de que as estratégias descritas no diagnóstico pela equipe médica e/ou psicopedagógica sejam executas, para que haja o melhor rendimento do aluno em suas atividades escolares. A partir da consulta a essas listas de alunos supostamente diagnosticados com transtornos de aprendizagem, as quais a pesquisadora por interesse pedagógico guardou, os possíveis sujeitos da pesquisa foram selecionados e suas famílias/responsáveis procuradas.

A partir do segundo semestre do ano de 2014, os responsáveis pelos possíveis sujeitos da pesquisa foram abordados via e-mail. Os responsáveis pelos possíveis sujeitos da pesquisa receberam, via e-mail, uma mensagem de apresentação, a qual explicava em detalhes quem era a pesquisadora; o motivo pelo qual aquele sujeito da pesquisa estava sendo convidado a participar; como aquele contato foi encontrado e selecionado; o objetivo da pesquisa; o método de obtenção das informações; o número de encontros necessários; os recursos a serem 
utilizados; a necessidade de acesso ao documento que afirma o diagnóstico de suposto transtorno de aprendizagem; os aspectos éticos e sigilosos da pesquisa; assim como o voluntarismo necessário e a inexistência de ganhos ou rendimentos por conta da participação na pesquisa.

É necessário esclarecer que, no primeiro contato com as famílias/responsáveis a pesquisadora pediu para que os possíveis sujeitos da pesquisa (menores de idade) fossem consultados quanto à participação ou não nesta pesquisa. Mesmo havendo a necessidade da autorização de um responsável maior de idade, a pesquisadora entendeu que os possíveis sujeitos da pesquisa precisavam estar de acordo em falar de suas vidas sem que houvesse nenhuma pressão, pois em uma pesquisa que convida o sujeito a falar de questões pessoais, de percepções integrais a respeito de si mesmo era necessário que houvesse o consentimento por parte de cada um, tendo em vista que para esta pesquisa elencamos alguns aspectos relevantes nesse processo que envolvem a vida dos sujeitos supostamente diagnosticados: aprendizagem, vivência, convivência social, auto-imagem, diagnóstico, escola, família e interesses.

Os familiares/responsáveis pelos sujeitos da pesquisa concordaram com a participação dos menores, forneceram os dados pessoais deles e dos menores viae-mail para o preenchimento do TCLE. Nas diferentes datas marcadas para as entrevistas descritas nas próximas páginas, os responsáveis pelos sujeitos da pesquisa assinaram os devidos termos (TCLE) que se encontram de posse da pesquisadora. 


\section{Capítulo 5 - ANÁLISES E PERCEPÇÕES}

\subsection{Análise de conteúdo: uma breve apresentação}

Entender o fenômeno da construção social dos transtornos de aprendizagem e da perpetuação da diferença a partir desse fato não depende somente de uma análise teórica da produção que orbita em torno da vida dos estudantes e das escolas. É também necessária a escuta atenta e a interpretação sensível dos enunciados dos sujeitos que estão envolvidos nesse processo, sujeitos estes que para nós são o centro de todo esse panorama: o aluno.

\subsection{Interação dos sujeitos com a pesquisa}

Para a produção de informações desta pesquisa, dispusemos de um encontro para entrevista com cada um dos participantes.

Os sujeitos da pesquisa continuam matriculados em escolas privadas do Distrito Federal, os três apresentam diagnósticos de supostos transtornos de aprendizagem, um deles apresenta uma reprovação recente justificada pela existência do suposto diagnóstico de transtorno de aprendizagem, deles apresentavam domínio sobre o que é o suposto diagnóstico e qual a sua função pedagógica, um deles não compreendia muito bem o que é o suposto diagnóstico, mas entendia qual a sua função.

\subsection{Resultado da interação}

Para apresentar as informações produzidas a partir das entrevistas realizadas com os três sujeitos participantes da pesquisa, separamos as entrevistas por data de agendamento, e os nomes dos sujeitos participantes foram substituídos por pseudônimos escolhidos pelos próprios sujeitos participantes, na intenção de preservar a identidade de cada um e deixá-los à vontade para a emissão das falas.

Entendemos que a melhor maneira de apresentar as informações obtidas a partir da interação com esses sujeitos foi à exposição da análise realizada sobre as informações produzidas pelos sujeitos expondo trechos genuínos das entrevistas. 


\title{
a. INTERAGINDO COM JASMIM
}

A entrevista foi realizada, no dia 15 de junho de 2015, às 13h30min com duração de uma hora.

Informações sobre Jasmim: ela tem 16 anos, está no $1^{\circ}$ ano do Ensino Médio, aluna reprovada em 2014, mudou de escola privada para outra escola privada em 2015.

A entrevista começou tranquila, Jasmim entendia o porquê estava ali. Começamos a entrevista com a apresentação da proposta da entrevista, a utilização do aparelho eletrônico de gravação de áudio e o roteiro para entrevista semiestruturada individual.

Para Jasmim a realidade do diagnóstico de suposto transtorno de aprendizagem era uma realidade que a acompanhava há muito tempo, de acordo com ela palavras como: dificuldade, aprendizagem, acompanhamento, reprovação e ajuda eram vocabulários comuns desde a sua infância.

O diagnóstico de suposto transtorno de aprendizagem de Jasmim teve seu início no ambiente escolar. Dentre as informações que Jasmim possui de quando era pequena, uma delas é a de que a mãe recebeu orientações de que ela não era como as outras crianças:

\begin{abstract}
A professora e a coordenadora da escola em que eu estudava chamaram a minha mãe para dizer que eu era diferente. Eu ainda era bem pequena, assim tinha uns 4 ou 5 anos. Disseram para ela que eu não aprendia como as outras crianças, que eu não me comportava e nem interagia como uma criança normal. Que era diferente. Acho que isso tudo começou por aí.
\end{abstract}

A busca por respostas para essas observações nascidas no meio escolar foram guiadas por outras observações dispostas nos anos subseqüentes por profissionais da área da educação como: psicopedagogos, coordenadores e orientadores escolares e profissionais da área de saúde como psicólogos e médicos.

Essa diferença a qual os sujeitos que compõem o corpo técnico-pedagógico da escola se referiam não era apenas de caráter meramente estatístico (não aprende como as outras crianças), mas não se manteve assim em relação a outras esferas e em outros momentos da vida de Jasmim, tendo sido valorada segundo diversos matizes ao longo do tempo como podemos observar em várias passagens desta pesquisa. 
Por causa dessa diferença observada pela escola e comunicada à família, Jasmim passa a ser percebida como um sujeito deslocado dentro do meio escolar, pois os estímulos propostos pelas diferentes professoras através das atividades elencadas não traziam da parte de Jasmim as respostas esperadas para sua idade/série:

\begin{abstract}
Eu não me lembro de estar no meio das crianças como todo mundo. Estava sempre com a professora. Eu sempre começava depois de todo mundo para poder a professora ficar perto de mim. Eu gostava de estar com a professora, mas eu fui crescendo e as crianças começaram a dizer que a professora ficava comigo, pois eu não sabia de nada. Aí eu ficava sem graça.
\end{abstract}

De acordo com Jasmim, a emissão do diagnóstico do suposto transtorno de aprendizagem foi muito útil para a família, para ela e para a escola:

O diagnóstico ajudou a escola a procurar maneiras de me tratar, de me ajudar a aprender, pois antes eu acho que as pessoas da escola nem sabiam que gente como eu aprende, mas é diferente. Não é que eu seja burra, não é que eu não aprenda. Eu aprendo diferente, eu sou mais lenta, mas acho que eu também aprendo. Não sei se tudo o que dizem sobre o meu problema está certo. Mas sei que tem coisas que eu aprendo diferente, mas eu consigo aprender.

O tratamento ao qual Jasmim se refere é aquele oferecido aos alunos que apresentam diagnóstico de suposto transtorno de aprendizagem, ou seja, aqueles alunos submetidos ao olhar daqueles que dispõem de uma compreensão e aplicação do conceito "aprender" que se encontra em sua generalidade e decorre da análise de sua repetição, sempre como essencialmente singular no contexto histórico no qual se encontram.

Dessa forma, o lugar de onde se enxerga a diferença é o lugar da generalidade, tal lugar exige da escola uma postura ativa na busca por estratégias que visem ao alcance da repetição. A escola, então, oferece algumas possibilidades que foram pensadas a partir das orientações das equipes consideradas especializadas (médicos, psicólogos, psicopedagogos, fonoaudiólogos, terapeutas ocupacionais, entre outros):

A minha mãe conta que a escola pediu para ela me levar para um médico para descobrir o que eu tinha, pois assim as coisas podiam ser resolvidas. Acho que esse problema de aprender é considerado doença. E quando a gente fala de doença a gente fica com medo né? Daí a minha mãe procurou 
ajuda. Acho que quando as coisas não estão bem tem que arrumar um jeito de consertar. Agora esse problema de aprender está mais popular, mais gente sabe, tem mais informação e tem muita gente que tem a mesma coisa que eu. Então eu acho que é melhor tratar para que a gente não fique se sentindo tão diferente, tão atrasado, tão incapaz.

Esse tratamento refere-se a rotinas e estratégias adotadas para a possível obtenção de melhores resultados no desenvolvimento pedagógico desses alunos, no desenvolvimento de suas capacidades, habilidades e competências. Tais rotinas e estratégias são defendidas pelos profissionais que as adotam como vias de efetivação da inclusão desses estudantes diagnosticados ao ambiente escolar.

A preocupação com as estratégias a serem utilizadas está diretamente ligada à obtenção de resultados concretos, visíveis, palpáveis no processo de aprendizagem e desenvolvimento desses sujeitos que nem sempre, ou na maioria das vezes não levam em consideração as singularidades de cada um, mas levam em consideração as exigências de equiparação dos deslocados, dos incapazes, dos deficitários em relação à média estatística que se encaixa no modelo burguês que perdura na sociedade atual: o aluno deve se adequar ao modelo geral e deve ser capaz de absorver os conteúdos desenvolvidos com eficácia no tempo e espaço determinados para esta aprendizagem, para que sua atuação na sociedade possa ser igualmente eficaz.

Dentre essas estratégias estão: a aplicação de provas diferenciadas, mais tempo para que o aluno realize a prova, um acompanhante para ler e orientar o aluno na hora da realização da prova (popularmente conhecido como ledor), a prova é aplicada em um ambiente separado dos demais alunos, atividades com prazos, critérios e parâmetros de avaliação diferenciados.

Estratégias como as citadas no parágrafo anterior comprovam a postura historicamente utilizada para o tratamento direcionado àqueles considerados diferentes, estas posturas têm como alicerce os processos de exclusão e nos permitem constatar que a segregação não ficou apenas em tempos passados, mas é uma postura de todas as épocas, incluindo a nossa contemporaneidade onde as políticas/ações mais utilizadas para lidar com aquele que é considerado incapaz apresenta a herança ontológica e filogênica de sua constituição.

Para Jasmim, a segregação, a exclusão, o tratamento diferenciado na maneira como sempre foi avaliada no contexto escolar era uma realidade conhecida em algumas das escolas privadas pelas quais passou: 
Eu fazia a prova diferenciada, às vezes na mesma sala, às vezes em uma sala separada. Ela não era mais fácil no meu ponto de vista, mas os colegas achavam que sim. Alguns até zoavam porque se a prova era "diferenciada" a gente não podia tirar nota baixa, pois a prova já era mais fácil, na ideia deles. E eu tirava sim nota baixa. Eu sofria com isso. Tinha medo de receber o resultado da prova, ficava com vergonha, me sentia mal, tipo assim diferente dos outros. A escola que eu estou agora não oferece a prova diferenciada, ela oferece um tempo a mais para a gente resolver a prova e entregar. Eu gosto mais desse jeito, as pessoas notam menos e a gente fica menos exposta.

Quando eu fazia prova diferenciada eu tinha momentos diferentes de medo. Eu tinha medo da prova antes dela acontecer. Depois eu ficava nervosa no dia, dava até um branco e eu ficava me cobrando depois. Para piorar tinha o dia de receber a prova com a nota. Era horrível. E desde que eu me lembro eu sempre fico em recuperação em muitas disciplinas e daí, como eu disse, os colegas zoavam, tipo assim, eu fazia prova diferenciada e ainda ficava para recuperação? É porque eu sou burra, lentinha, devagar, coisas do tipo.

As estratégias para o alcance da equiparação dos sujeitos diagnosticados com supostos transtornos de aprendizagem não se restringem apenas aos processos avaliativos, as rotinas podem variar entre especificar um assento determinado em um local estratégico da sala que vise à maior atenção por parte do aluno em relação à aula, assim como maior atenção do professor em relação aquele aluno diagnosticado supostamente com transtorno de aprendizagem; anotações periódicas por parte dos professores sobre o desenvolvimento e postura do aluno para serem entregues à coordenação/orientação; atendimento periódico por parte da coordenação/orientação escolar para ouvir o aluno, o corpo docente e a família sobre avanços e dificuldades daquele aluno.

No caso de Jasmim, as rotinas incluíam e ainda incluem o atendimento com ela, com a família e o feedback dos professores:

Alguns professores entendem que gente como eu aprende diferente, é diferente, mas tem professor que acha que é preguiça ou falta de estudo. Minha mãe sempre é chamada para conversar com a coordenação, saber como estou em casa, se tenho psicólogo, professor particular, se faço esporte, se tenho namorado, se estou feliz com a escola, essas coisas assim. Também me chamam e me perguntam essas coisas. Também perguntam em que disciplina me sinto melhor, se eu acho que estou aprendendo e se estou tomando algum remédio para ajudar com meu problema. Mas não estou tomando remédio nenhum. Não sei se preciso, mas se precisar eu acho que tomo sem problema.

Mas essa ida na sala da coordenação tem coisas boas e tem coisas ruins. Quando alguém vai para a coordenação é porque tem algum problema: está doente, fez besteira, vai levar bronca, precisa de alguma coisa ou tem alguma coisa diferente. No meu caso eu tenho a coisa diferente, eu sou aquelas alunas que precisam de ajuda. Às vezes é bom, às vezes ir lá é legal, mas às vezes não é legal, pois os colegas ficam observando e parece 
que a gente sempre vai lá porque tem problema. Mas a gente também vai lá para ser elogiado ou para receber algum recado e também responder perguntas.

No caso específico de Jasmim a mudança de escola também foi ocasionada pela reprovação que aconteceu em 2014. Uma das justificativas da escola para a reprovação de Jasmim foi a de que a aluna não acompanhou a proposta pedagógica da escola. Em contraponto a essa afirmativa Jasmim argumenta que:

A antiga escola não entendia o meu problema ou não queria me ajudar. Sei lá. Minha mãe foi chamada lá poucas vezes, não tinha prova diferenciada e nem tinha mais tempo para resolver a prova. Eu nunca fui à sala da coordenadora ou da orientadora conversar. Acho que eles não estavam preparados para receber alunos como eu. Saí de lá e foi melhor para mim. Estou mais feliz na nova escola. Lá também não tem a prova diferenciada, mas tem um tempo a mais para pensar e resolver a prova. Para mim está bom até agora. O colega não tem motivo para zoar gente como eu por causa da prova "diferente".

A escola como ambiente de partilha e desenvolvimento de habilidades, competência e conhecimento avalia o aluno assim como também é avaliada por ele, como podemos ver na fala de Jasmim logo acima. A inserção do diagnóstico de suposto transtorno de aprendizagem nesse ambiente pode ser vista de muitas maneiras, a dimensão que o diagnóstico alcança para a família, para o diagnosticado e para a escola não é a mesma. Para a família; o diagnóstico vem como uma via de acesso e entendimento a uma situação desconhecida por eles; para o diagnosticado, a emissão do diagnóstico é uma faca de dois gumes: pode ocasionar um melhor tratamento por parte da escola ou não e pode gerar a exposição dos mesmos aos demais componentes do ambiente escolar; para a escola, a emissão do diagnóstico é vista como a orientação para o tratamento dos alunos com supostos transtornos de aprendizagem.

O problema da exposição é o que mais afeta aos alunos diagnosticados com suposto transtorno de aprendizagem, pois antes de tudo são crianças e adolescentes que querem e precisam ser aceitos, querem fazer parte dos grupos de sua idade, não querem ser diferentes:

Eu não gosto de ser diferente. Se eu pudesse seria igual a todo mundo. Mas não dá para fazer nada com isso. Acho que já nasci assim. Mas eu tenho que conviver com isso. Tenho amigos, namorado, vou às baladas, quero fazer faculdade, mas não sei do que ainda (risos). Acho que gente como eu não pode baixar a cabeça, tem que aceitar ajuda dos profissionais 
e da família. A minha mãe me apóia muito, sei que é difícil para ela, mas ela me ama e me apóia.

A diferença não é vista como singularidade, a singularidade é vista como diferença e apontada como um problema a ser tratado, consertado, cuidado, tratado a partir da busca por uma causa, da identificação de seus efeitos e da prescrição de um tratamento a partir do diagnóstico. Nesse momento o sujeito tem sua autonomia expropriada de si, em virtude da suposta doença que apresenta e sente ser retirada de si sua identidade por não ser igual aos demais. Com a perda da identidade perde-se também a autoridade sobre si e o sujeito passa a aceitar que o outro diga quem ele é, o que deve fazer a partir dali e como deve enxergar a si próprio:

Acho que ninguém gosta de ser ou de se sentir diferente, mas como eu não tenho como livrar disso, eu tenho é que aprender a conviver comigo. $\mathrm{Na}$ minha casa eu sou a única que tem esse problema, mas não me sinto muito mal com isso. A minha mãe não faz comparações entre as filhas, eu e a minha irmã. Mas nos outros lugares como a escola eu já me senti mal. Não tenho certeza do que os outros pensam, sei lá, não estou na cabeça deles, mas já fui zoada por causa disso e não fiquei feliz. Acho ruins algumas coisas, tipo assim, horários de estudos controlados, pois tem a orientação, não gostava de fazer a prova diferenciada, não gostava e não gosto até hoje de ter que ir a alguns médicos, tipo psicólogo. E uma coisa que me incomoda às vezes é ficar sendo lembrada que eu tenho que estudar mais, pois eu não sou como as outras pessoas. Isso eu já sei. Mas também sei que eu também consigo aprender as coisas, pode ser mais difícil para mim, mas eu acabo aprendendo com dificuldade, mas eu aprendo. Quando me interesso, quando alguma coisa me chama atenção eu aprendo. Tem coisas mais fáceis e tem coisas mais difíceis. Acho que é assim para todo mundo não é?

Para o aluno médio, ou o aluno que, em média, aprende o tratamento oferecido pelas equipes especializadas que atuam dentro da escola é diferente daquele direcionado aos alunos como Jasmim que apresentam diagnóstico de suposto transtorno de aprendizagem. Esse tratamento específico envolve uma troca de informações e posturas que influenciam em todas as esferas da vida do sujeito e que é refletida em características como a autonomia, a auto-imagem e interação do sujeito com os demais:

Nunca tive muitos amigos, sempre fiquei na minha. Às vezes é mais fácil assim. Tem menos gente para zoar você, porque no mundo tem muita gente ignorante e intolerante e que não respeita os outros. Não entende a dificuldade e os problemas que os outros passam. Mas eu tenho os meus amigos, como já te disse tenho vida social. Eu namoro, vou às festas, uso o Facebook, lá tenho um monte de amigos, você pode ver lá se você quiser. Eu acho que essa coisa de me sentir mal por ser diferente vai passar algum 
dia. Tipo no dia em que eu me formar e tiver um emprego. Acho que isso de me sentir mal é porque a escola é um lugar de muita competição e de muita comparação. A gente fica o tempo todo sendo cobrado e se você não é como os outros, você se sente mal. A escola fala de resultados o tempo todo, agora além da nota que você tem que tirar para passar de ano tem o Enem, tem o PAS da UnB e tem o vestibular. Aí todo mundo tem que ter nota boa para a nota da escola ser boa nos exames. Aí tem os cursos que todo mundo quer, aí você não sabe o que escolher. Aí você lembra que não dá para competir com os melhores, porque você vai ter muita dificuldade e a coisa só se complica.

Mas tem que passar pela escola né? Ninguém vai para a faculdade direto. Não sei o que quero fazer (risos). Já pensei em um monte de coisas, Teatro, Música, Moda, Direito. Toda hora quero uma coisa diferente. Acho que vou decidir lá na hora. Tem tempo ainda e eu ainda tenho que terminar o ensino médio.

Para além da visão das equipes especializadas, da família e da escola sobre o sujeito diagnosticado com suposto transtorno de aprendizagem está a visão dele mesmo sobre o que acontece a partir do surgimento deste diagnóstico, mas que está intrinsecamente influenciada por todos os outros sujeitos constituintes de suas relações interpessoais:

Não acho ruim ter ajuda. Queria que todo mundo como eu tivesse ajuda. Eu sei que preciso me esforçar um pouco mais. Às vezes aprendo somente depois da aula com o professor particular. Mas eu aprendo. Não sei muitas coisas, mas sei que posso aprender. As pessoas não entendem direito esse problema.

É esse problema de aprender é complicado. Tem gente que não entende porque não sabe, tem gente que não entende porque não quer. Tem gente que nem sabe que ele existe você sabia disso?

Ao terminar a interação com Jasmim, ela descreveu alegria em poder compartilhar essas ideias, impressões e sensações. Afirmou esperar ter ajudado em alguma coisa com as coisas que disse.

\section{b. INTERAGINDO COM ROSA}

A entrevista foi realizada, no dia 22 de junho de 2015, às 13h30min com duração de uma hora.

Informações sobre Rosa: ela tem 16 anos, está no $1^{\circ}$ ano do Ensino Médio, permanece na mesma escola privada há pelo menos 5 anos.

A entrevista começou tranquila, mas Rosa apresentava muita tensão. Com o desenvolvimento da entrevista as preocupações que ocasionavam a tensão de Rosa foram sendo esclarecidas e ela foi ficando mais à vontade. 
Para Rosa, as questões a respeito do diagnóstico não eram novidade. Ela tinha conhecimento do motivo pelo qual estava ali sendo entrevistada. Rosa deixou claro que não tinha problemas em falar sobre sua "dificuldade de aprender", pois para ela não era vergonha nenhuma agora:

Antes para eu falar sobre isso era motivo de vergonha, mas hoje é tão comum. Tem um monte de gente que tem, sabia? E as pessoas estudam, trabalham e vivem mesmo assim. Mas claro que é não é normal. Se fosse normal a gente não precisava de ajuda, como as outras pessoas não precisam de ajuda. Mas não acho que seja, tipo "doença". Acho que é um problema que já nasce com a gente e daí a gente fica diferente dos outros. Nem todo mundo entende.

Como posso explicar esse problema para você? (Pausa). Nasce com a gente como quem precisa usar óculos, ou quem tem diabetes ou pressão alta, ou toma remédio para o coração. Mas isso que eu estou falando são doenças.

O que eu tenho é diferente, não é bem doença como estas que eu falei agora, mas é alguma coisa que me faz aprender diferente dos outros.

De acordo com Rosa, os indícios de sua diferença no processo de aprendizagem em relação às outras crianças foram detectados pela escola do Ensino Fundamental I, mas só foi apontado como um problema no Ensino Fundamental II. Sua percepção é que no Ensino Fundamental I a escola procurou resolver junto à família esse problema, mas no Ensino Fundamental II quando ela já estava na adolescência à escola apontou sua "lentidão" em assimilar os conteúdos como algo a ser resolvido rapidamente, pois as singularidades de cada situação particular de aprendizagem como acontece no caso de Rosa, tornam-se irrelevantes para o resultado final, de caráter estatístico que se baseia em um critério de normalidade exterior à estatística em si, mas utilizado por ela em sua aplicação prática no que concerne à educação e a outras esferas da vida social.

O olhar de Rosa sobre sua experiência escolar no Ensino Fundamental II é de muita dificuldade e angústia, pois após a emissão do diagnóstico de suposto transtorno de aprendizagem muitas coisas se modificaram na vida de Rosa com relação à escola:

Eu passava muito mal do estômago na escola, principalmente nas aulas de exatas. Eu ficava sem comer. Tive problemas alimentares, fiquei bulímica (acho que o nome é esse). Sentia muita dor pelo corpo. Estava sempre saindo de sala para ir ao banheiro ou à coordenação, tinha professor que não entendia e achava que eu estava fugindo da aula e até me falava isso. Perdi peso. Era sempre assim na escola. Por causa desse sofrimento eu tive problema cardíaco e até operei. O médico disse que muitas coisas que 
eu tinha eram psicológicas e ele entendeu que era por causa do meu problema de aprender.

Eu tinha medo de tudo na escola, achava que não ia dar conta de nada. Passava muito mal mesmo. Quando falava em prova e nota eu fica muito mal mesmo. Eu não acreditava que as coisas podiam dar certo e então eu me fechava. Falava com poucas pessoas na minha sala e na minha escola. Eu notava que até me achavam estranha, mas eu também me achava estranha.

Para a família de Rosa de acordo com ela, foi um processo difícil, pois não havia problema deste tipo antes. A relação entre Rosa e a família passou a ser de cuidados médicos e acompanhamento da sua vida escolar. Para Rosa, tudo ficou mais claro em relação ao problema de aprendizagem em sua adolescência:

\begin{abstract}
Quando fiquei adolescente as coisas ficaram complicadas, eu tinha outros interesses e como não aprendo rápido eu me distraía com facilidade. Aí vinham as provas e eu não me saí bem, mesmo fazendo uma prova "especial", feita para alunos que têm problema. (Pausa longa). Desculpa! É que eu me lembrei que era um tempo muito complicado. Eu passava muito mal na maioria das aulas e ficava doente perto das provas e eu passei a me cortar, principalmente quando saíam os resultados. Minha família nunca soube desse fato e foi um colega de sala que descobriu e me ajudou me aconselhando.

Depois esse colega se tornou meu namorado. Ele me dizia que não era vergonha ser diferente e que ninguém é igual no mundo. Nem os gêmeos são iguais. Eu me sentia bem ouvindo as coisas que ele me dizia, ele parecia tão seguro das coisas que dizia para mim, mas quando eu estava sozinha, quando estava sem ele e quando tinha que ser avaliada tudo voltava e eu ficava me sentindo mal novamente.

Depois que a gente terminou o namoro a gente ficou muito amigo, como a gente era antes de namorar e ele ainda continua me aconselhando e apoiando. Ele entende o meu problema, mas ele não é como eu, assim ele não tem dificuldade, ele é "normal".
\end{abstract}

A relação entre o diagnóstico de suposto transtorno de aprendizagem e escola para Rosa foi vista como um facilitador de sua aprendizagem, pois a escola procurou atender as solicitações que "seu" problema apresentava. O papel da coordenação de apoio e monitoração das estratégias pedagógicas necessárias para seu desenvolvimento foi visto por Rosa como bastante eficiente. Ela acredita que sem o diagnóstico de suposto transtorno de aprendizagem nem ela, nem a família e nem a coordenação iriam saber como cuidar dela.

Rosa apresenta uma visão otimista quanto ao papel do diagnóstico. Não ficou claro na construção das informações se Rosa possui um olhar realista sobre os alcances do diagnóstico em relação à vida político-social em toda a sua plenitude, envolvendo principalmente o imaginário daqueles que estão relacionados com a 
situação ou o problema em questão: a própria Rosa, a família, o meio social e os constituintes do ambiente escolar.

É da crença de Rosa que foi depois de entender que as coisas acontecem lentamente para ela, mas acontecem, que houve nela o desejo de superar essas "dificuldades". Neste ano de 2015, ela não está mais fazendo uso da prova diferenciada. Por livre e espontânea vontade, solicitou à coordenação que sua prova fosse igual a dos outros colegas:

Não quero mais fazer a prova que os colegas dizem que é "fácil". Quero fazer aprova igual à de todo mundo, pois no vestibular não vai ter uma prova especial para mim. Se eu me der mal na prova normal, outras pessoas que não têm problema de aprendizagem também vão se dá mal e ninguém vai ridicularizar ninguém. Se eu tirar uma nota boa, outros também vão tirar nota boa e vai ficar por isso mesmo. Não vai ter ninguém para dizer que a minha nota é boa porque a minha prova é diferenciada. Sinto-me normal assim, igual a todo mundo. É um alívio. E sabe de uma coisa? Os resultados, assim as notas, têm sido as mesmas de quando eu fazia a prova diferenciada. Tem hora que são boas, tem hora que são ruins, como a de todo mundo. Nunca são as melhores da sala, mas nunca foram mesmo (Risos).

A junção do diagnóstico com as práticas e estratégias de trabalho propostas pela escola ou implementadas pela escola a partir do aconselhamento das equipes especializadas, produz perversamente um ambiente propício à rotulação do sujeito diagnosticado. Este mesmo sujeito se vê solitário, diferente, excluído, incapaz, limitado quando comparado às medidas que têm a normalidade como parâmetro. Mas o que é normal? Essa pergunta pode ser encontrada nos discursos dos sujeitos desta pesquisa, se não diretamente, mas indiretamente, quando questionam o porquê de tanto problema em razão de sua condição de diferença. Condição esta instituída socialmente e que ganha dimensões em todas as esferas da vida do sujeito:

Pessoas como eu aprendem. Eu aprendo. Só aprendo diferente. (Pausa). Isso é tão ruim assim? E se todo mundo fosse igual seria bom? Não sei. Eu não me sinto tão diferente dos outros. Eu sou adolescente e quero as coisas da minha idade como os outros adolescentes. Fico incomodada com essa coisa de ser tratada como doente. Mas não sou doente. Mas é bom saber o que eu tenho, o que eu consigo, onde preciso de ajuda, pois assim eu sei que sou capaz de fazer muitas coisas e que outras serão difíceis para mim. Mas todo mundo acha umas coisas fáceis e outras coisas difíceis. Vai ver que gente que aprende mais do que eu acha difícil coisas que eu acho fácil. Mas acho que essa pessoa deve ter menos dificuldade do que eu e por isso ela é "normal". 
Se eu pudesse ser diferente do que sou eu seria, teria menos sofrimento, iria fazer menos esforço para acompanhar os outros na hora de aprender e acho que eu seria mais feliz. Não é que eu não seja feliz, mas é complicado tem sempre muita cobrança, muita coisa para fazer, muita gente de olho e às vezes eu me sinto sufocada.

Rosa acredita que não é fácil ser diferente, pois para tudo na vida existe um padrão. Para coisas que pesam muito na vida das pessoas, no caso dos adolescentes mais ainda, coisas como a beleza, o dinheiro, a moda e o modo de aprender:

A gente que tem algum problema se sente diferente, pois todos os outros parecem semelhantes entre si, eu não vou dizer iguais, pois igual é complicado, acho que nem os gêmeos são iguais como eu já disse. Mas claro que quando você não está no padrão você é estranha. Tipo assim, a gente se sente fora da panelinha, meio deslocada. Tem grupo para tudo, até para a gente os diferentes, o grupo dos isolados. É complicado. Agora está menos complicado, já tenho amigos, tinha namorado, mas acabou. Acho que estou mais madura e as coisas estão mudando.

Alguns dos meus amigos, desses amigos que eu falei são pessoas como eu que também tem problemas para aprender. São problemas iguais e outros diferentes. Depois que eu descobri que aprendo diferente dos outros também descobri que tem vários tipos de problema assim. Tem até famosos (risos) que tem essas coisas.

Ao terminar a interação com Rosa, ela descreveu alívio em dividir o que pensava a respeito do tema com a pesquisadora. Declarou estar com medo de falar certas coisas, mas que depois de saber do sigilo que envolve esse tipo de trabalho, ficou mais tranqüila. Também disse que todos que passam pelos mesmos problemas que ela deveriam ter uma oportunidade como essa de serem ouvidos.

\section{INTERAGINDO COM SAMAMBAIA}

A entrevista foi realizada, no dia 25 de junho de 2015, às 18h30min com duração de uma hora.

Informações sobre Samambaia: ele tem 13 anos, está no $8^{\circ}$ ano do Ensino Fundamental, permanece na mesma escola privada há pelo menos 6 anos.

A entrevista começou muito silenciosa por parte do sujeito da pesquisa com respostas monossilábicas, pois Samambaia apresentava muita timidez. Com o desenvolvimento da entrevista a timidez foi dando lugar a uma conversa tranquila e com a interação desejada. 
No caso de Samambaia, a realidade do diagnóstico de suposto transtorno de aprendizagem se apresentou de forma muito atípica. A mãe, ao saber do diagnóstico que ela também teve em sua juventude, não quis compartilhar com 0 filho a princípio, pois acreditava que o diagnóstico de suposto transtorno de aprendizagem poderia ser um empecilho para o desenvolvimento do filho e preferiu observar como seriam suas experiências a partir daquele momento.

De acordo com as informações construídas por Samambaia a respeito do que pensava sua mãe e de como agiu frente à emissão de seu diagnóstico de suposto transtorno de aprendizagem, podemos constatar que para a mãe aderir a uma postura de não utilização do diagnóstico como forma de tratamento diferenciado por parte da escola para com o seu filho, seria uma forma de evitar várias situações que poderiam surgir a partir dali.

Dentre essas situações podemos supor a existência da profecia Autorrealizadora, pois os alunos rotulados pela abordagem diagnóstica terminam por receber tratamento notoriamente diferente, e em pouco tempo estão questionando seu próprio desenvolvimento cognitivo, suas capacidades, suas possibilidades e acabam por confirmar o diagnóstico. Assim, o diagnóstico se auto-realiza, se concretiza na vida do sujeito de forma a naturalizar todos os desdobramentos consequentes a partir da sua emissão.

Em função desta postura materna Samambaia, veio ter ciência da existência do suposto transtorno de aprendizagem recentemente. Para ele todas as informações a respeito do assunto são uma novidade, mas ele não apresenta preocupação quanto a isso:

\footnotetext{
Não sei muito o que te dizer a respeito, sei que não é uma doença. Sei que a minha mãe tem a mesma coisa. Às vezes acho que eu aprendo umas coisas devagar e outras, rápido. Mas até um dia desses nem sabia que tinha esse problema. Tenho dificuldade em umas disciplinas e tenho facilidade em outras, mas vejo que isso acontece com outros colegas também. No meu caso eu vejo isso acontecer com todo mundo. Tem uns alunos que se destacam como os melhores da turma, mas são poucos. A maioria é como eu, tira nota alta e também tira nota baixa, assim é normal para todo mundo.
}

Samambaia acredita que por causa da postura da mãe, que o deixou viver na escola como as outras crianças que não apresentam diagnóstico de suposto transtorno de aprendizagem, ele nunca precisou ser medicado. Não tem recordações de nenhuma medicação a não ser para febre ou algum tipo de dor. Ele 
se reconheceu como um menino tímido, com poucos amigos e que fala pouco, mas não relaciona isso com o diagnóstico:

\begin{abstract}
Sempre fui reservado e depois que descobri o problema de aprender continuo com os mesmos amigos. O que mudou é que a escola ofereceu para mim e para a minha mãe a prova especial, na minha escola chama-se prova diferenciada. É uma prova para pessoas que têm problemas como esse que o médico disse que eu tenho. Mas eu não quero fazer. Acho que não preciso. Até hoje nunca fiz essa prova diferenciada, sempre fiz a prova igual a dos outros. Nas provas me saio bem, tem prova que não. Eu acho que vou melhor nas disciplinas que eu gosto mais do assunto e também quando eu gosto mais do professor. Tem professor que é muito chato e que a aula dele é chata. Mas tem uns professores que são legais, engraçados e que querem que a gente fique sempre interessado pela aula e aí é legal. Nessas aulas eu não sinto dificuldade e tenho boas notas nas provas.
\end{abstract}

Socialmente o diagnóstico de dificuldade de aprendizagem não tem sido um peso para Samambaia, pelo que ele apresentou. Ele relatou que na sua escola esse tipo de diagnóstico é muito comum, que os alunos não sentem vergonha de dizer que tem diagnóstico e que alguns tentam tirar vantagem disso, pois algumas facilidades existem para aqueles que têm problema:

\begin{abstract}
Os colegas que tem problema chegam para os professores dizendo que precisam de mais tempo para fazer tudo (entregar trabalho, fazer tarefa, fazer prova), porque eles têm problema e que a coordenação sabe disso. Tem colega que até fala que não tomou o remédio naquele dia e que não está bem e nem está entendendo nada. Eu acho esquisito, mas não digo nada. Tem uns colegas que acham graça e falam que também querem remédio e querem fazer a prova diferenciada. Eu não faço a prova diferenciada e nem quero fazer. Os caras pegam no pé de quem faz dizendo que a prova é boba. Mas fico pensando coisas como: por que a prova diferenciada é vista como boba, ela não é especial para quem precisa e quer fazer? Pelo que o médico diz seria bom para mim fazer essa prova, mas eu não quero. Acho que estou bem como estou, se um dia eu precisar talvez eu aceite, mas até hoje não precisei. Também não quero que fiquem mexendo comigo. Sou muito na minha, calado, falo com meus amigos, mas iria ficar muito chateado e não sei o que faria se passasse por brincadeira dos colegas por causa disso. Não quero fazer a prova especial, não quero problemas. Está bom assim.
\end{abstract}

A escola, cumprindo as determinações ou digamos as orientações das equipes especializadas, acaba por delegar à Medicina o planejamento das atividades que devem ser realizada com esses sujeitos diagnosticados, quando na verdade a escola deveria ser a protagonista dos processos de ensino-aprendizagem levando em consideração as diversidades de comportamentos, personalidades, etnias, históricos sociais, limitações e necessidades que os sujeitos carregam, como já discutimos anteriormente neste trabalho: 
Não sei se é necessário que o médico diga como deve ser as coisas comigo na minha escola. Quando eu não sabia deste problema eu não precisava ser tratado como diferente e estava tudo bem. Agora que eu sei, não quero que as coisas mudem. Não sou criança mais e entendo que esse problema pode trazer outros problemas. As pessoas entendem pouco e tem preconceito, eu vejo isso com os colegas que têm esse mesmo problema. Também tem os espertos que não estão nem aí e que ficam zoando com o próprio problema, tentando se sair bem, tentando conseguir nota de um jeito mais fácil. Mas eu não quero ficar usando o problema, minha mãe me disse que assim eu não vou fazer coisas diferentes na vida, pois vou ficar preso ao que o médico falou. Eu prefiro ficar como estou.

Na relação com a família, Samambaia apoia a decisão tomada pela mãe. Ele disse que se estivesse no lugar dela ele faria a mesma coisa, pois quando ela contou para ele o motivo pelo qual esperou para contar sobre o diagnóstico de suposto transtorno de aprendizagem, justificou que ele tinha condições de superar o diagnóstico, assim como ela fez no passado, quando esses diagnósticos ainda eram muito menos detalhados que hoje em dia. Samambaia acredita que a mãe fez a melhor escolha para ele:

Ela acreditou em mim. Mas como a escola olha muito esse negócio de rendimento e as minhas notas não são as melhores, a minha mãe foi chamada para essas conversas com a coordenação. Daí ela teve que avisar à escola e teve que contar para mim sobre o diagnóstico. Aí a escola fez a oferta da prova diferenciada, mas eu não quero fazer e a minha mãe me apoiou. Prefiro ficar assim. Para mim sempre foi assim, fazer as coisas que os outros fazem. Às vezes dá certo e às vezes não dá certo.

Entendemos, portanto, que Samambaia compreende, no vocábulo que the é comum, que para a escola não interessa ou não é possível lidar com a sua singularidade, pois de acordo com a análise estatística, o que a escola busca são resultados concretos do processo de aprendizagem dos alunos, o que é incompatível com o trabalho necessário para lidar com as diferentes características de cada aluno no tocante ao aprender.

O ponto de partida essencial da estatística é sempre a homogeneidade, lugar este onde muitas pessoas não se encontram quando estamos discutindo o processo de aprender. Tais pessoas são, então, identificadas e orientadas a ter uma ação que as conduza a este lugar da homogeneidade proposto e desejado pela escola.

As estratégias propostas pela escola não convencem Samambaia de que as coisas podem melhorar para ele caso ele aceite. Como todas as informações sobre o diagnóstico de suposto transtorno de aprendizagem são novas, ele prefere 
continuar com sua vida escolar de sempre. Declarou ter medo das mudanças que o diagnóstico pode trazer para a vida dele, mudanças que ele considera ruins:

Não quero tomar remédio, acho que não preciso. Até agora tenho aprendido o que preciso. Não me sinto tão diferente dos outros. Não sou o mais inteligente, mas não sou burro. Não preciso dessas ajudas de prova diferente. Sou como todo mundo, mas talvez eu aprenda mais devagar ou diferente, não sei bem como é isso. Mas não quero que as coisas mudem. Sei que quem tem esse problema que eu tenho não fica feliz com isso. Tem uns que sofrem muito, porque os colegas ficam julgando e têm outros que nem ligam e ficam usando esse negócio para tirar vantagem. Eu quero ficar assim como estou. Se um dia eu precisar eu falo com a minha mãe e a gente vai decidir o que fazer.

As percepções de Samambaia a respeito de sua vida a partir do diagnóstico e do que isso influencia no seu futuro são muito claras. Ele acredita que o diagnóstico não importa muito, se ele não ficar focado no diagnóstico de suposto transtorno de aprendizagem. Samambaia acredita que vai ser como a mãe que conseguiu muitas coisas e também tem o mesmo problema. Para ele esse é o caminho: buscar a superação:

O exemplo da minha mãe é ótimo. Ela disse que no tempo dela essa história de problema para aprender era nova e que não tinham muitos estudos. Ela acha que era mais fácil naquela época porque não tinha tantas exigências como tem hoje, assim de nota, de colocação no vestibular e nessas provas para entrar na faculdade. Mas agora tem remédio para tudo e ela acha que o remédio pode até me ajudar a aprender, mas pode também me deixar diferente. Tem remédio que faz bem e tem remédio que faz mal. Eu não quero tomar agora. Quero fazer as coisas como sempre fiz. Não entendo direito toda essa história ainda como já te disse, mas está bom assim como sempre foi, não quero mudar.

No tocante à medicalização do sujeito diagnosticado, levamos em consideração um dos aspectos deste processo: o uso da prescrição do fármaco, do remédio. Na fala de Samambaia fica evidente a preocupação com os efeitos dessa ação, do uso do remédio para apreender. A reação ao uso desse tipo de droga é diferente de pessoa para pessoa. Alguns alunos apresentam reações esperadas apresentadas na bula e que afirmam a eficácia do produto, outros apresentam as consideradas reações adversas. São estas reações adversas que preocupam Samambaia e sua mãe, reações como letargia, desânimo, sonolência e outros sintomas derivados do uso da medicação. 
Mas muitas vezes a medicalização da vida escolar unida às expectativas da escola com relação à intervenção médica na vida do sujeito que não aprende, os sujeitos envolvidos estão militantes na busca por resultados positivos a partir do uso dessa medicação e dos processos de tratamento destes sujeitos diagnosticados que não levam em consideração tais sintomas adversos do uso da medicação.

Para Samambaia, o problema de aprender deve existir realmente, pois até a ciência fala sobre isso. Mas ele não vê isso como um obstáculo para crescer na vida e nem a necessidade, no seu caso, do uso da medicação. Quando perguntado sobre a experiência de falar do diagnóstico de suposto transtorno de aprendizagem, ele sorriu e disse que não entende muito sobre esse problema, mas que é bom falar com alguém que entende, referindo-se à pesquisadora. 


\section{Capítulo 6 - CONSIDERAÇÕES FINAIS}

Este trabalho percorreu uma longa trajetória até este ponto e, agora, faz-se interessante estabelecer, como uma síntese, que trajetória foi essa, evidenciando e explicitando vínculos lógicos e epistemológicos que possam ter sido esmaecidos pelo caráter analítico de cada capítulo.

As perspectivas que cada sociedade tem sobre conceitos como "dificuldade de aprendizagem e desenvolvimento" são de suma importância, pois estabelecem como aqueles que recaem sob tais conceitos irão ser tratados, tanto na dimensão ética, interpessoal, como nas práticas políticas que tal sociedade irá desenvolver.

No capítulo 1, mostramos que os conceitos de "dificuldade de aprendizado e desenvolvimento" não são de caráter biológico, natural, como uma essência que os conceitos estão apreendendo, mas construções sociais historicamente datadas que elegem determinada característica como referência para tais conceitos, muitas vezes com base em uma ontologia aceita no período. Assim, mostramos que para um platônico, ter "dificuldade de aprendizado e desenvolvimento" se referiria a não ter recordações suficientes; para um agostiniano, ter "dificuldade de aprendizado e desenvolvimento" se referia a não ter iluminação divina suficiente; enquanto que, para o período moderno e contemporâneo, ter "dificuldade de aprendizado e desenvolvimento" se refere a não ter ritmo ou eficiência relativa aos esquemas de produção (material ou intelectual) suficiente. Assim, "memória", "graça" e "ritmo" formam os condicionantes de fundo sobre os quais se assentam os conceitos de "dificuldade de aprendizado e desenvolvimento".

Em todos os casos apresentados, sob uma análise estrutural, as perspectivas estabeleceram e estabelecem tais dificuldades por uma ausência que estaria no sujeito. O que a análise mostra é que tais noções são construídas como uma relação entre as exigências do modelo em voga (religioso, burguês, entre outros) e o comportamento do indivíduo frente aos mecanismos que o modelo desenvolve para impor tais exigências, em especial na educação.

Diferentemente das perspectivas estritamente filosóficas ou religiosas, a conceituação moderna surge em um ambiente social que demanda que tais condicionantes de fundo (os ritmos) sejam racionalmente justificados. Assim, a partir do modelo de racionalidade adotado pela modernidade, amplamente calcado nas noções de cientificidade, torna-se um passo natural tentar ancorar tais "problemas 
de ritmo" em estados biológicos objetivos, uma vez que tal objetividade remove da relação justamente a sua parte condicionante - o sistema econômico, político ou ideológico em voga.

Dessa forma, a perspectiva moderna sobre "dificuldades de aprendizado e desenvolvimento" encontrou na Psicologia e na Psiquiatria sua ancoragem objetiva gerando uma ideologia da medicalização. Não sendo mais um problema da relação do indivíduo com exigências impostas pela organização social, há que se tratarem as "dificuldades de aprendizado e desenvolvimento" na sua fonte pressuposta, ou seja, o indivíduo. Sendo de origem biológica ou natural, devem-se tratar tais problemas com medicamentos que possam restabelecer o funcionamento "correto" do substrato biológico ("correto", ou seja, naturalmente correto, e não "mais adequado" ao sistema vigente).

Faz-se necessário, porém, não apenas estabelecer uma justificativa formal para os procedimentos que o sistema irá adotar politicamente e eticamente com as pessoas que recaem sob os conceitos de "dificuldade de aprendizado e desenvolvimento", mas de mostrar que tais dificuldades estão objetivamente onde se supõem estarem: uma necessidade que acompanha o modelo cientificista.

Nesse sentido, a ideologia da medicalização acaba por produzir seus próprios mecanismos de autovalidação ou autojustificação. Uma criança apresentando um comportamento "muito" questionador, que diminui os ritmos de apresentação de conteúdos, é qualificada como TOD e a ela é receitado algum medicamento que não raro a coloca em situação de prostração, eliminando o "problema". Uma criança que divaga "muito", que desvia a todo instante os caminhos de exposição dos conteúdos e influencia nos ritmos de apresentação destes, é qualificada como TDAH e a ela é receitado algum medicamento capaz de "fixar sua atenção naquilo que importa". A criança assim tão bem ajustada aos requisitos do modelo social vigente apresenta, algumas vezes, melhora na aquisição dos conteúdos escolares considerados necessários e nos ritmos de aquisição destes conteúdos, "justificando" o próprio procedimento.

Nos casos em que a medicação não é suficiente, criam-se modelos de tratamento do indivíduo, como é o caso da prova diferenciada, para que possam recolocá-los nos ritmos impostos. O raciocínio, portanto, é o seguinte: "Veja! Após a medicação o aluno melhorou muito! Sinal de que precisava mesmo da medicação"; ou: "Olha só! Eles têm mesmo dificuldade de aprendizado e desenvolvimento, pois 
só com a prova diferenciada podem evoluir nos estudos". Ao final, esse é o critério de objetividade que se pode alcançar da ideologia da medicalização e estratégias de ensino a ela correlatas.

Após algum tempo sob tais estratégias, o aluno, prostrado pela medicação e imbecilizado pelas provas diferenciadas (nome astuto para provas que são meramente mais fáceis), de fato passa a não ser capaz de aprender mais nada, seja de que modo se faça a apresentação do conteúdo. Conclui-se, portanto, que ele tinha mesmo um "problema". As práticas ficam justificadas a posteriori e, com elas, o próprio sistema que as instituiu.

Com a modernidade recrudesceu não apenas a atitude classificatória claramente haurida dos DSMs, que terminam por sindromizar todo o comportamento humano, mas também recrudesceu a atitude de se avaliar o resultado da educação - elemento importante para a verificação da eficiência desejada (basicamente um controle de qualidade).

Surgiu, então, outro fundamento para a validação das práticas educacionais e suas imposições quanto a ritmos: a análise estatística. Dessa análise surge, por pressuposto das técnicas empregadas, uma classe de indivíduos estatisticamente medianos, regidos por uma distribuição estatística dita "normal"27. A passagem do "normal" estatístico, um mero cálculo de resultados relativos a avaliações (que, digase, pressupõe esse "normal" relativamente às práticas), para um "normal" comportamental, que abstrai das práticas para incidir no indivíduo, apresenta-se como quase natural, até mesmo evidente, ou mesmo imediata.

$E$, no entanto, não é. A estatística, como mecanismo de análise, como vimos no capítulo 3, já parte de uma noção de medianidade, que abstrai das diferenças dos indivíduos para instituir um elemento abstrato médio (não raro concretamente inexistente na amostra). Todas as formas que a estatística usa para alcançar (ou recuperar), posteriormente, as diferenças, têm a noção de média como fundamento.

Esse mecanismo de análise é uma formalização da estrutura já apresentada no capítulo 1 que, qualifica "dificuldade de aprendizado e desenvolvimento" como uma falta, uma ausência de algo que recolocaria o indivíduo no seu estado adequado (de memória, de graça ou de ritmo).

\footnotetext{
27 Há um teorema em estatística, chamado "Teorema do Limite Central" que estabelece que, para amostras muito grandes, uma classe de resultados muito grande é aquela regida pela curva gaussiana, dita distribuição normal.
} 
Qualquer mecanismo de inclusão que se deseje haurir desse modelo terá sempre um aspecto de concessão ou favor. A prova diferenciada é uma de tantas concessões possíveis. Com ela a avaliação "volta a funcionar" e criam-se duas classes de indivíduos: os normais e os diferentes.

Entretanto, no humano, o diferente não é uma classe ou conjunto. O normal estatístico aqui é uma mera abstração. Concretamente, na existencialidade humana há apenas o diferente. Não um diferente que se contrapõe a um normal, mas um diferente que se contrapõe a outros diferentes, sem que com isso se constitua uma classe de normalidade (para além da estatística).

Esse diferente, que não se deixa contrapor a uma classe de normalidade, que é índice de humanidade e individualidade, é precisamente o que consideramos aqui de singularidade. A singularidade, portanto, é uma mudança de paradigma, pela qual nos abstemos de estabelecer qualquer perspectiva sobre o normal comportamental na educação. Não se trata, evidentemente, de cessar de analisar estatisticamente resultados de avaliações, mas de bloquear a passagem dessas médias estatísticas a medianidades existenciais. Assim, tais resultados deixam de falar apenas dos indivíduos que realizaram as avaliações, e passam a falar também das próprias avaliações e dos modelos de educação que as induziram.

Tal singularidade, nas suas oposições ao mediano, tem, ademais, um elemento subjetivo e, no entanto, concreto no qual se assentar. Trata-se do malestar, que seria um sentimento do indivíduo de que o seu meio educacional é inóspito. Um índice individual da exclusão efetivamente sentida. Tal mal-estar é necessariamente individual e não se reduz, de modo algum, a uma doença do indivíduo, ainda que possa ter fundamento eventualmente também em alguma doença, mas jamais apenas nela.

O capítulo quatro mostra como crianças medicadas permanecem envoltas em um profundo sentimento de mal-estar.

A ideia de que o humano é perpassado pela singularidade (e não diferença coordenada por um referencial de medianidade) tem como sua proposta pedagógica fundamental a erradicação do mal-estar por práticas de ensino que já tenham essa singularidade como pressuposto. 


\section{REFERÊNCIAS}

AGOSTINHO. Confissões. São Paulo: Abril, 2005.

ARANTES, Valéria A. Inclusão escolar: pontos e contrapontos. São Paulo: Summus, 2006.

ARISTÓTELES. Categories. In: The complete works of Aristotle. New Jersey: Princeton University Press, 1984.

. Physics. In: The complete works of Aristotle. New Jersey: Princeton University Press, 1984.

. Politics. In: The complete works of Aristotle. New Jersey: Princeton University Press, 1984.

. Política. São Paulo: Abril, 2004.

ARNS, Flávio. LDB: Lei de Diretrizes e Bases da Educação. Brasília, 2004.

ASSOCIAÇÃO BRASILEIRA DE NORMAS TÉCNICAS. NBR 14724: Informação e documentação: trabalhos acadêmicos: apresentação, Rio de Janeiro, 2011.

Rio de Janeiro, 2002.

NBR 6023:Informação e documentação: referências: elaboração,

NBR 10520: Informação e documentação: citações em documentos:

apresentação, Rio de Janeiro, 2002.

ASSOCIAÇÃO DE PSIQUIATRIA AMERICANA (APA). Manual Diagnóstico e Estatístico de Transtornos Mentais: DSM V. Porto Alegre: Artmed, 2014.

BASTOS, Fernando. Panorama das ideias estéticas no ocidente: de Platão a Kant. Brasília: UnB, 1987.

BOEHNER, Philotheus; GILSON, Etienne. História da filosofia cristã. Petropólis: Vozes, 1970.

BRANDÃO, Carlos R. Pesquisa participante. São Paulo: Brasiliense, 1981.

. Pesquisa participante. São Paulo: Brasiliense, 1982.

A pergunta em várias mãos: a experiência da partilha através da pesquisa na educação. São Paulo: Cortez, 2003.

. (Org.). Pesquisa participante. São Paulo: Basiliense, 2006.

BRASIL. Constituição da República Federativa do Brasil. Brasília, 1988. Disponível em: <http://www.planalto.gov.br/ccivil 03/constituicao/Constituicao.htm>. Acesso em: 30 jan. 2014. 
BRASIL. ECA - Estatuto da Criança e do Adolescente Lei n 8.069. Brasília, 13 de julho de1990. Disponível em: <http://www.planalto.gov.br/ccivil 03/leis/l8069.htm>. Acesso em: 10 abr. 2014.

L. Lei de Diretrizes e Bases da Educação Nacional n 4.024. Brasília, 20 de dezembro de 1961. Disponível em: <http://wwwp.fc.unesp.br/ lizanata/LDB\%204024-61.pdf>. Acesso em: 10 abr. 2014.

. Lei de Diretrizes e Bases da Educação Nacional n 9.394. Brasília, 20 de dezembro de 1996.1 Disponível em: <http://portal.mec.gov.br/arquivos/pdf/ldb.pdf>. Acesso em: 10 abr. 2014.

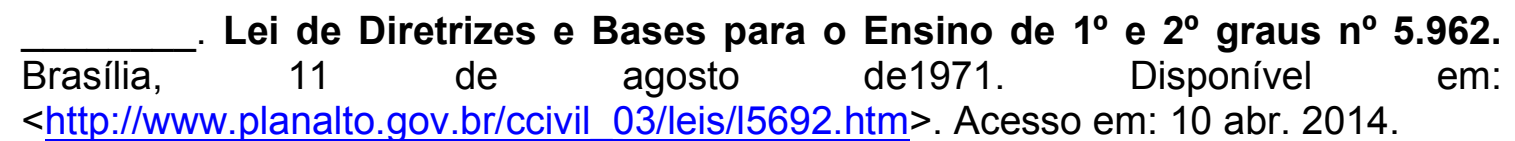

BRUNI, J. C. Foucault: o silêncio dos sujeitos. São Paulo: Tempo Social, 1989.

CAMPBELL, Selma Inês. Múltiplas faces da inclusão. Rio de Janeiro: Wak, 2009.

CAVALCANTE, F. G. Pessoas muito especiais: a construção social do portador de deficiência e reinvenção da família. Tese (Doutorado em Saúde Pública ). Rio de Janeiro: Escola Nacional de Saúde Pública - Fiocruz, 2002.

CRESWELL. John W. Projeto de pesquisa: métodos qualitativo, quantitativo e misto. Porto Alegre: Artmed, 2010.

DROGA. In: Britannica Escola Online. Enciclopédia Escolar Britannica, 2014. Web, 2014. Disponível em: <http://escola.britannica.com.br/article/481175/droga>. Acesso em: 2 jul. 2014.

FLICK, Uwe. Introdução à pesquisa qualitativa. Porto Alegre: Artmed, 2009.

FOUCAULT, Michel. Doença mental e psicologia. Rio de Janeiro: Tempo Brasileiro, 1975.

Perspectiva, 2000.

Michel. História da loucura na Idade Clássica. São Paulo:

FONSECA, Vitor. Psicomotricidade: filogênese, ontogênese e retrogênese. 2 ed. Porto Alegre: Artmed, 1998.

FREIRE, Paulo. Pedagogia da autonomia: saberes necessários à prática educativa. Rio de Janeiro: Paz e Terra, 2014.

GALVÃO, Ana Luiza; ABUCHAIM, Cláudio Moojen. Transtornos psiquiátricos na infância. Disponível em: <http://www.abcdasaude.com.br/psiquiatria/transtornospsiquiatricos-na-infancia>. Acesso em: 6 jun. 2015. 
GERALDI, João Wanderley. In: MOYSÉS, Maria Aparecida Affonso. A institucionalização do invisível: crianças que não aprendem na escola. São Paulo: Mercado das Letras, 2001.

GRANSHOW, L; PORTER, R. The hospital in history. London: Routledge, 1989.

ILLICH, Ivan. A expropriação da saúde: nêmesis da medicina. Rio de Janeiro: Nova Fronteira, 1975.

LAKATOS, Eva Maria; MARCONI, Marina de Andrade. Metodologia científica. São Paulo: Atlas, 2011.

LIPMAN, Matthew. A Filosofia vai à escola. São Paulo: Summus, 1990.

O pensar na educação. Petrópolis, RJ: Vozes, 1995.

LIPMAN, M. SHARP, A.; OSCANIAN, F. S. A filosofia na sala de aula. São Paulo: Nova Alexandria, 1994.

MARCONDES, Danilo. Iniciação à história da filosofia dos pré-socráticos a Wittgenstein. São Paulo: Zahar, 2002.

MARINOFF, Lou. Pergunte a Platão. Rio de Janeiro: Record, 2003.

MATOS, Lúcio F. S.; RUDOLF, Édimo C. Formas de ensinar da Idade Média à contemporaneidade e razões para o ensino de engenharia ser como é. In: Anais do XXXIV COBENGE. Universidade de Passo Fundo, set. 2006. Disponível em: $<$ http://www.abenge.org.br/CobengeAnteriores/2006/artigos/9 186 222.pdf>.

Acesso em 22 out. 2014.

MEC/SEESP. Política Nacional de Educação Especial na Perspectiva da Educação Inclusiva. Portaria No 555/2007. Brasília, 07 de janeiro de 2008. Disponível em: <http://portal.mec.gov.br/arquivos/pdf/politicaeducespecial.pdf>. Acesso em: 20 set. 2014.

MEIRA, Marisa Eugênia Melillo. Incluir para continuar excluindo: a produção da exclusão na educação brasileira à luz da Psicologia Histórico-Cultural. In: $\mathrm{FACCl}$, Marilda Gonçalves Dias; MEIRA, Marisa Eugênia Melillo; CALVO, Silvana.

MENDONÇA, Martha. Revista Época. Rio de Janeiro: Globo, 2011.

METZLER, Irina. Disability in medieval Europe. London: Routledge, 2006.

MORAES, Paula Louredo. Discalculia, sintomas, causas e tratamento, [s.d.]. Disponível em <http://www.brasilescola.com/doencas/discalculia.htm>. Acesso em: 4 jun. 2015.

MOYSÉS, Maria Aparecida Affonso. A institucionalização do invisível: crianças que não aprendem na escola. São Paulo: Mercado das Letras, 2001. 
NOVAES, Hillegonda M. D. In: MOYSÉS, Maria Aparecida Affonso. A institucionalização do invisível: crianças que não aprendem na escola. São Paulo: Mercado das Letras, 2001.

ONU. Convenção sobre o direito das pessoas com deficiência. Decreto $\mathrm{N}^{\circ}$ 6.949. Brasília, 25 de agosto de 2009. Disponível em: <http://www.planalto.gov.br/ccivil 03/ ato2007-2010/2009/decreto/d6949.htm>.

Acesso em: 20 set. 2014.

PESSOTTI, Isaías. Deficiência mental: da superstição à ciência. São Paulo: T.A., 1983.

PLATÃO. Diálogos. São Paulo: Abril, 1972.

. Fédon. São Paulo: Abril, 1972.

Sofista. São Paulo: Abril, 1972.

A República. Lisboa: Fundação Caloustre Gulbenkian, 1993.

REALE, Giovanni; ANTISERI, Dario. História da filosofia: antiguidade e Idade Média. São Paulo: Paulus, 1990.

REALE, Miguel. Lições preliminares de direito. São Paulo: Saraiva, 1991.

ROHDE, Luís Augusto P.; BENCZIK, Edyleine B. P. Transtorno de déficit de atenção/hiperatividade: o que é? Como ajudar? Porto Alegre: Artes Médicas, 1999.

SAMPAIO, Simaia. Dificuldades de aprendizagem: a psicopedagogia na relação sujeito, família e escola. Rio de Janeiro: Wak, 2011.

SILVA, Tadeu. A produção social da identidade e da diferença. Disponível em: < http://www.diversidadeducainfantil.org.br>. Acesso em 20 set. 2014.

VINOCUR, Evelyn (Rev.). Síndrome de Asperger, [s.d.]. Disponível em: <http://www.minhavida.com.br/saude/temas/sindrome-de-asperger>. Acesso em: 4 jun. 2015.

[s.n.]. Síndrome do pensamento acelerado: conheça o problema e saiba como contorná-lo, [s.d.]. Disponível em: <http://www.contioutra.com/sindrome-dopensamento-acelerado-conheca-o-problema-e-saiba-como-contorna-lo/>. Acesso em: 4 jun. 2015.

SOLOMON, R. C; HIGGINS, K. M. The big questions: a short introduction to philosophy. Belmont: Paperback, 2009.

[s.n]. Transtorno opositivo-desafiante, [s.d.]. Disponível em: <http://transtornosdeaprendizado.com/crian a desafiante>. Acesso em: 5 jun. 2015. 
TULESKI. (Orgs.). A exclusão dos "incluídos": uma crítica da psicologia da educação à patologização e medicalização dos processos educativos. Maringá: EDUEM, 2011.

TUNES, Elizabeth; BARTHOLO, Roberto. Nos limites da ação: preconceito, inclusão e deficiência. São Carlos: EdUFSCar, 2010.

UNESCO. Declaração de Salamanca: sobre princípios, políticas e práticas na área das necessidades educativas especiais. Salamanca-Espanha: UNESCO, 1994. Disponível em: <http://portal.mec.gov.br/seesp/arquivos/pdf/salamanca.pdf>. Acesso em: 30 jan. 2014.

$\begin{array}{ccc} & \text { Relatório de monitoramento de educação para todos. EPT - França: } \\ \text { UNESCO, } & 2008 . & \text { Disponível }\end{array}$ $<$ http://unesdoc.unesco.org/images/0018/001871/187129por.pdf>. Acesso em: 30 jan. 2014.

VILLAS BOAS, Benigna M. F. Virando a escola do avesso por meio da avaliação. Campinas, São Paulo: Papirus, 2013.

VYGOTSKY, Lev. S. Pensamento e linguagem. São Paulo: Martins Fontes, 1987.

A formação social da mente. São Paulo: Martins Fontes, 1989.

Obras escogidas: fundamentos de defectologia. Madri: Visor, tomo $\mathrm{V}$ 1997. 


\section{APÊNDICES}


APÊNDICE A - Termo de consentimento livre e esclarecido

\author{
$\checkmark$ \\ Universidade de Brasília - UnB \\ Faculdade de Educação - FE \\ Programa de Pós-Graduação em Educação - PPGE
}

\title{
TERMO DE CONSENTIMENTO LIVRE E ESCLARECIDO
}

Você está sendo convidado(a) a participar, como voluntário(a), da pesquisa As contribuições da filosofia da diferença na era dos alunos com supostos transtornos de aprendizagem -, no caso de você concordar em participar, favor assinar ao final do documento. Sua participação não é obrigatória, e, a qualquer momento, você poderá desistir de participar e retirar seu consentimento. Sua recusa não trará nenhum prejuízo em sua relação com o pesquisador(a) ou com a instituição.

Você receberá uma cópia deste termo onde consta o telefone e endereço do pesquisador(a) principal, podendo tirar dúvidas do projeto e de sua participação.

NOME DA PESQUISA: As contribuições da filosofia da diferença na era dos alunos com supostos transtornos de aprendizagem

PESQUISADOR(A) RESPONSÁVEL: Ana Bárbara da Silva Nascimento

ENDEREÇO: SHIS QL 14 Conjunto Casa 15 Lago Sul

TELEFONE: 3248.6164 / 9296.8255

PESQUISADORES PARTICIPANTES: Orientadora Profa. Dr. Sílvia Ester Orrú

PATROCINADOR: Nenhum

OBJETIVOS: Investigar a trajetória escolar dos alunos selecionados, no intuito de compreender se existem ou existiram contribuições feitas pela disciplina de Filosofia no desenvolvimento da aprendizagem destes alunos que supostamente apresentam diagnóstico de dificuldade de aprendizagem. 
PROCEDIMENTOS DO ESTUDO: Concordando em participar da pesquisa, o(a) menor sobre sua responsabilidade terá que participar de uma entrevista oral (gravada com aparelho de áudio) sobre a trajetória escolar do mesmo(a). A entrevista terá a participação apenas da pesquisadora e do menor sobre sua responsabilidade. A entrevista será realizado em um local neutro com a presença do(a) menor e a pesquisadora responsável, em data a ser marcado pelos participantes da pesquisa de acordo com suas conveniências.

A pesquisa consiste em fazer uma investigação e propor uma reflexão sobre o papel do professor, da família, da escola, do médico, das equipes psicopedagógicas na constituição deste aluno supostamente diagnosticado e apontar que vias de superação (se existirem estas vias) para que não se reproduza a profecia autorealizadora do fracasso ou limitação escolar com e destes estudantes. Uma destas vias de superação seria o ensino de Filosofia a partir do uso do arcabouço intelectual e existencial próprios dessa área do conhecimento.

A pesquisa será realizada através da revisão da literatura e do referencial teórico, somados aos dados da pesquisa de campo que será realizada através da entrevista individual.

Os dados coletados durante os encontros servirão para respaldar as ideias geradas durante o desenvolvimento do pré-projeto e do próprio projeto da pesquisa, que busca investigar a veracidade e validade das impressões e suspeitas que o pesquisador carrega, quanto ao ensino de Filosofia e sua contribuição para o desenvolvimento de alunos diagnosticados com supostos transtornos de aprendizagem.

RISCOS E DESCONFORTOS: A pesquisadora acredita que o risco que pode haver no percurso da pesquisa (Entrevista) é o desconforto do entrevistado em relatar algum fato que possa fazer parte da pauta do instrumento a ser utilizado. Porém, fica claro aqui que todas as necessidades e demandas dos participantes serão respeitadas.

BENEFÍCIOS: A pesquisa tem a intenção de trazer para a comunidade acadêmica, a comunidade escolar, as famílias, os profissionais da área e os estudantes uma contribuição sobre o trabalho da disciplina de Filosofia com os estudantes que apresentam um suposto diagnóstico de dificuldade de aprendizagem. Com esta 
investigação teórica e prática, a pesquisa busca contribuir para uma reflexão sobre o papel do professor, da família, da escola, do médico, das equipes psicopedagógicas na constituição deste aluno supostamente diagnosticado e apontar que vias de superação (se existirem estas vias) para que não se reproduza a profecia autorealizadora do fracasso ou limitação escolar com e destes estudantes.

CUSTO/REEMBOLSO PARA O PARTICIPANTE: A pesquisadora informa que os sujeitos de pesquisa não arcarão com nenhum gasto decorrente da sua participação (entrevista e grupo focal). O encontro para a entrevista não incidirá em nenhuma cobrança a ser feita aos participantes em relação ao que será realizado. Também fica claro aqui que os participantes da pesquisa não receberão qualquer espécie de reembolso ou gratificação devido à participação na pesquisa.

CONFIDENCIALIDADE DA PESQUISA: A pesquisadora garante total sigilo dos dados pessoais e da identidade dos participantes da pesquisa. Todos os nomes serão substituídos por pseudônimos para que em momento algum os dados da pesquisa possam, no corpo do texto, identificar os participantes da mesma. A pesquisadora assegura também a privacidade dos sujeitos quanto aos dados confidenciais envolvidos na pesquisa, informando que somente serão divulgados dados diretamente relacionados aos objetivos da pesquisa.
Assinatura
do
Pesquisador
Responsável: 
APÊNDICE B - Consentimento de participação da pessoa como sujeito

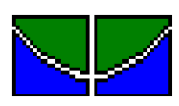

Universidade de Brasília - UnB

Faculdade de Educação - FE

Programa de Pós-Graduação em Educação - PPGE

\title{
CONSENTIMENTO DE PARTICIPAÇÃO DA PESSOA COMO SUJEITO
}

\begin{abstract}
$\mathrm{Eu}$,
responsável pelo(a) menor: declaro que li as informações contidas nesse documento, fui devidamente informado(a) pelo pesquisador(a) - (Ana Bárbara da Silva Nascimento) - dos procedimentos que serão utilizados, riscos e desconfortos, benefícios, custo/reembolso dos participantes, confidencialidade da pesquisa, concordando ainda em participar da pesquisa. Foi-me garantido que posso retirar o consentimento a qualquer momento, sem que isso leve a qualquer penalidade. Declaro ainda que recebi uma cópia desse Termo de Consentimento.
\end{abstract}

LOCAL E DATA: Brasília,

NOME E ASSINATURA DO SUJEITO OU RESPONSÁVEL (menor de 21 anos): 


\title{
APÊNDICE C - Roteiro para entrevista semi-estruturada individual
}

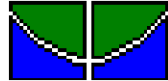 \\ Universidade de Brasília - UnB \\ Faculdade de Educação - FE \\ Programa de Pós-Graduação em Educação - PPGE
}

\section{ROTEIRO PARA ENTREVISTA SEMI-ESTRUTURADA INDIVIDUAL:}

(Referência para construção deste instrumento: CRESWELL. John W. Projeto de pesquisa: métodos qualitativo, quantitativo e misto. Porto Alegre: Artmed, 2010).

- Entrevista oral,

- Gravada com autorização por escrito,

- Gravador digital.

Entrevistado(a)/Pseudônimo:

Data:

Local:

Questões:

1. O que vc entende por transtornos de aprendizagem?

2. Você acha que tem alguma dificuldade de aprendizagem?

3. Conte o que você pensou ou sentiu quando começou a ouvir afirmações sobre a sua suposta dificuldade de aprendizagem.

4. Você recebeu algum diagnóstico médico?

5. Como se sentiu quando recebeu esse diagnóstico?

6. Você tomou algum medicamento?

7. Como você descreve a sua relação com os professores após o diagnóstico?

8. Como você descreve a sua relação com a família após o diagnóstico?

9. A escola tratava você de modo diferente dos demais colegas? Como?

10. Qual a sua visão a respeito da escola hoje, a partir das suas experiências? 
11. O que você entende por diferente e diferença?

12. Como você gostaria que a escola o visse e o tratasse?

13. Você considera que tem um transtorno de aprendizagem tal como diz o diagnóstico ou você considera que aprende do seu jeito?

14. Se todos pudesse o ouvir, o que você gostaria de dizer a respeito dessa sua vivência?

15. Gostaria de dizer algo mais? 


\title{
APÊNDICE D - Passo a passo da entrevista semi-estruturada individual
}

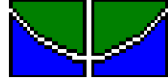 \\ Universidade de Brasília - UnB \\ Faculdade de Educação - FE \\ Programa de Pós-Graduação em Educação - PPGE
}

\section{PASSO A PASSO DA ENTREVISTA SEMI-ESTRUTURADA INDIVIDUAL:}

No primeiro momento de cada encontro em particular o mesmo passo a passo de execução da entrevista foi apresentada aos três sujeitos. A seguir apresentamos o passo a passo:

- Nome da pesquisadora;

- Instituição a qual a pesquisadora está vinculada;

- Título da pesquisa;

- Objetivo da pesquisa;

- Roteiro para entrevista semiestruturada individual;

- Instrumento de registro das falas dos sujeitos (gravador digital e anotações em uma ficha de acompanhamento);

- Os motivos pelos quais o convite foi feito aquele sujeito;

- A dinâmica da pesquisa com: perguntas, respostas, mediações;

- As considerações éticas e sigilosas da pesquisa;

- Por fim, o sujeito da pesquisa foi deixado à vontade para pausar, terminar, suspender ou não responder às perguntas que desejar ou não a qualquer tempo.

Encontramos relevância na apresentação da rotina de execução da entrevista aos sujeitos participantes, pois se tratavam de sujeitos inexperientes quanto a este tipo de trabalho. A apresentação da rotina de execução da entrevista buscava orientar e tranqüilizar o sujeito da pesquisa quanto ao que iria acontecer durante aquele encontro. 